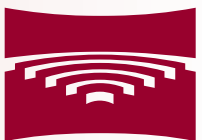

RígAs STRADINA UNIVERSITĀTE

\title{
leva Bāgante
}

\section{DEGUNA ELPOŠANAS FUNKCIJA UN ESTĒTIKA BĒRNIEM AR VIENPUSĒJU CAUREJOŠU LŪPAS, ALVEOLĀRĀ IZAUGUMA UN AUKSLĒJU ŠĶELTNI}

Promocijas darbs medicīnas doktora zinātniskā grāda iegūšanai Specialitāte - mutes, sejas un žoḳ̣u k̦irurğija 
Ieva Bāgante

\title{
DEGUNA ELPOŠANAS FUNKCIJA UN ESTĒTIKA BĒRNIEM AR VIENPUSĒJU CAUREJOŠU LŪPAS, ALVEOLĀRĀ IZAUGUMA UN AUKSLĒJU ŠKELTNI
}

\author{
Promocijas darbs \\ medicīnas doktora zinātniskā grāda iegūšanai
}

Specialitāte - mutes, sejas un žokḷu ḳirurgijija

Darba zinātniskā vadītāja:

Dr. med. profesore Ilze Akota

Rīga, 2018 


\begin{abstract}
ANOTĀCIJA
Lūpu un aukslēju šķeltnes ir biežākā iedzimtā patoloğija sejas un žokḷu rajonā. Vienpusējas caurejošas lūpas, alveolārā izauguma un aukslēju šķeltnes gadījumā vienmēr novēro tipisku deguna deformāciju. Tā kā deguns ir novietots sejas centrālajā daļā, tā izskatam ir ievērojama ietekme kopējā sejas estētikā. Pētījumi par iedzimtām sejas šķeltnēm joprojām ir aktuāli, jo nav vienotas pieejas par šādu deformāciju korekcijas laikiem un metodiku, lai panāktu gan labu funkcionālu, gan estētisku rezultātu. Arī diskusijas par deguna estētikas novērtēšanas metodēm pacientiem ar lūpu un aukslēju šķeltnēm joprojām ir aktuālas. Deguna estētikas objektīvai un kvantitatīvai novērtēšanai līdz šim nav aprakstītas vispāratzītas metodes.
\end{abstract} Tāpat nav noteikti vispāratzīti mērāmie parametri, pēc kuriem noteikt deguna estētiku.

Lai varētu novērtēt deguna un augšlūpas estētiku un deguna elpošanas funkciju bērniem ar vienpusēju caurejošu lūpas, alveolārā izauguma un aukslēju šķeltni, nepieciešamas objektīvas un êrti lietojamas metodes, ar kurām varētu kvalitatīvi un kvantitatīvi noteikt ārstēšanas rezultātus.

Pētījumā veikta detalizēta literatūras avotu analīze par deguna estētikas novērtēšanas metodēm, apkopojot to pozitīvos un negatīvos aspektus. Literatūrā visbiežāk deguna estētika tika noteikta divdimensiju (2D) fotoattēlos. Pētījuma pirmajā dạ̄ā tika iekļauti 27 bērnu 2D fotoattēli deguna estētikas noteikšanai ar modificētu Anastassov un Chipkov (2003) detalizēto vērtēšanas skalu un vizuālo analogu skalu. Līdz šim šāda detalizēta deguna estētikas novērtēšanas skala mērījumiem 2D fotoattēlos literatūrā nav bijusi aprakstīta. Pēc datu statistiskās apstrādes konkrētajai pētījuma grupai varēja secināt, ka izvēlētās metodes objektivitāte nebija pārliecinoša. Pētījuma otrajā daḷā deguna simetrijas novērtēšanai tika izmantoti trīsdimensiju (3D) fotoattēli ar antropometrisko punktu atlikšanu. Literatūras dati liecināja, ka deguna simetrijas mērījumi 3D fotoattēlos ir bijuši objektīvi. Pētìjuma otrajā daļā tika iekļauti 35 bērni ar vienpusēju caurejošu lūpas, alveolārā izauguma un aukslēju šķeltni un tika izmantota inovatīva aparatūra un metode deguna un augšlūpas simetrijas novērtēšanai 3D fotoattēlos un deguna elpošanas funkcijas noteikšana ar priekšejju rinomanometriju, salīdzinot ar kontroles grupu.

Rezultātā deguna anatomiskā forma pēc plastiskajām vienpusējas caurejošas lūpas, alveolārā izauguma un aukslēju šķeltnes operācijām bija atjaunota, tomēr deguna simetrija pētījuma grupā atšķīrās no kontroles grupas. Pacientiem ar vienpusēju caurejošu lūpas, alveolārā izauguma un aukslēju šķeltni pēc rinoplastikas elpošanas plūsma caur veselo pusi bija labāka nekā caur škseltnes pusi. Kontroles grupā elpošana bija labāka nekā pacientiem ar vienpusēju caurejošu lūpas, alveolārā izauguma un aukslēju šķeltni. Deguna simetrijas 
novērtējums 3D fotoattēlos ar detalizētiem antropometriskiem mērījumiem bija kvalitatīvi un kvantitatīvi vērtējams, bet deguna estētikas novērtējums 2D fotoattēlos ar izvēlētajām novērtēšanas metodēm uzrādīja subjektīvus rezultātus.

Deguna simetrijas noteikšanai rekomendējams izmantot 3D fotoattēlus ar izvēlētajiem antropometriskajiem punktiem. Šajā pētījumā lietotie antropometriskie punkti un attālumi deguna un augšlūpas simetrijas noteikšanai rekomendējami lietot klīnikā rutīnā. Rinomanometriju ieteicams veikt kā rutīnas izmeklējumu pirms un pēc deguna ķirurǵiskas ārstēšanas. 


\begin{abstract}
ANNOTATION
Cleft lip and palate is the most frequent congenital craniofacial deformity. Nose deformation is remarkable in patients with complete unilateral cleft lip, alveolus and palate. As the central feature of the face, the nose has a profound effect on general facial aesthetics, making it clearly abnormal in appearance and function in patients with clefts. Rhinoplasty for cleft lip and palate patients is very challenging owing to its complex pathology, and also frustrating because the final postoperative outcome is limited. Also, the timing and methods of nasal correction differ among clinics. The outcome of the nose surgery is difficult to evaluate, due to the three-dimensional complexity of its shape. Discussions of aesthetic evaluation of the nose in patients with cleft lip and palate remain problematical, many different methods having been described in the literature. However, there is no single reliable method for aesthetic evaluation of the nose for patients with clefts and there is no consensus about measurements, either.
\end{abstract}

To evaluate nasolabial appearance and nasal function in patients with complete unilateral cleft lip, alveolus and palate objective, convenient methods are required so that the results of treatment can be assessed qualitatively and quantitatively.

Literature analysis was done concerning aesthetic evaluation of the nose in patients with cleft lip and palate and positive and negative aspects of the methods were identified. The most popular evaluation method in articles was two-dimensional (2D) photography. In the first part of the study, 27 children with complete unilateral cleft lip, alveolus and palate were included for nasal aesthetic evaluation in 2D photos with modified Anastassov and Chipkov (2003) scheme and visual analogue scale. So far, this detailed aesthetic assessment scale for measuring nose in 2D photos was not described in the literature. The objectivity of the chosen method, after statistical data processing for a particular study group, was not convincing. In the second part of our study for evaluation of nasolabial symmetry three-dimensional (3D) photos with selected anthropometric landmarks were used. Measurements of the nasolabial symmetry in $3 \mathrm{D}$ photos were described as objective method in the literature. In the second part of study, 35 patients with complete unilateral cleft lip, alveolus and palate were included for evaluation of nasolabial appearance and nasal function enabling comparing with a group of unaffected children.

The nasolabial appearance with acceptable symmetry after cleft lip and reconstructive surgery of the nose was achieved. However, symmetry of the nasolabial appearance in patients with complete unilateral cleft lip, alveolus and palate differed from control group. In control group and in non-cleft side of nose of patients with complete unilateral cleft lip, alveolus and 
palate nasal flow was better than in cleft side. The 3D photos with proposed set of anthropometric landmarks for evaluation of nasolabial appearance seems to be qualitative and quantitative method, but nasal aesthetic evaluation in 2D photos with proposed methods showed subjective results.

For nasolabial appearance evaluation 3D photographs and anthropometric landmarks and distances should be used. The set of anthropometric landmarks and distances used in our study, might be proposed to assess nasolabial appearance after surgery routinely. Rhinomanometry could be suggested as routine examination before and after secondary nose corrections. 


\section{SATURS}

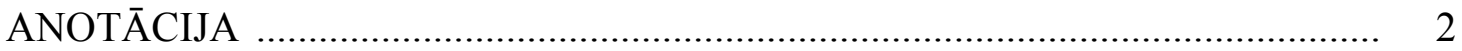

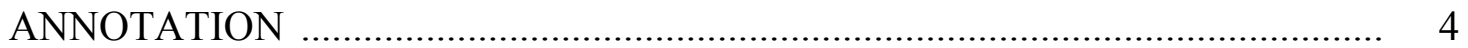

DARBĀ LIETOTIE SAİSINĀJUMI .............................................................. 8

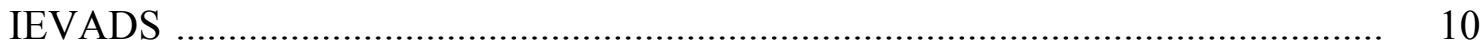

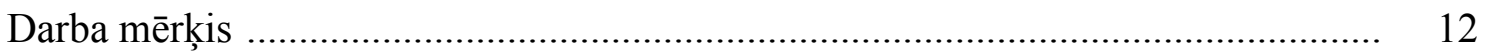

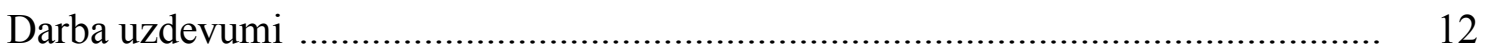

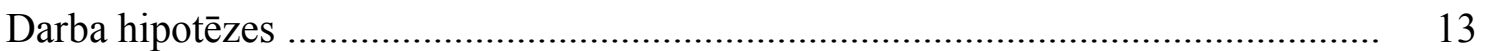

Darba zinātniskā novitāte un praktiskā vērtība ..................................................... 13

1. LITERATŪRAS APSKATS ….............................................................. 14

1.1. Vienpusējas caurejošas lūpas, alveolārā izauguma un aukslēju šķeltnes klīniskā anatomija ................................................................................. 14

1.2. Vēsturisks ieskats par pacientu vecumu deguna koriǵējošām operācijām ... 17

1.3. Primāra deguna plastika.......................................................................... 17

1.3.1. Primāras deguna plastikas korekcijas laiki ...................................... 19

1.3.2. Nazoalveolārās platītes lietošanas lietderīgums............................... 19

1.3.3. Primāras deguna plastikas ķirurğiskās tehnikas............................... 21

1.4. Sekundāra deguna plastika .................................................................. 24

1.4.1. Sekundāras deguna plastikas korekcijas laiki................................. 24

1.4.2. Sekundāras deguna plastikas ķirurgisiskās tehnikas .......................... 25

1.4.3. Skrimšļa un kaula transplantācija ................................................ 27

1.5. Deguna elpošanas funkcija ..................................................................... 28

1.6. Deguna estētikas novērtēšanas metodes ................................................. 29

1.6.1. Klīniska ................................................................................. 30

1.6.2. Divdimensiju fotoattēli .............................................................. 31

1.6.3. Trīsdimensiju fotoattēli............................................................ 32

1.6.4. Cefalogrammas un datortomogrāfija ........................................... 32

1.6.5. Sejas ğipša veiduḷi.................................................................. 33

1.6.6. Video ieraksti ........................................................................ 34

1.7. Deguna estētikas novērtēšanas mērāmie parametri ................................... 35

1.7.1. Antropometriskie mērījumi....................................................... 35

1.7.2. Graduēto skalu mērījumi.............................................................. 40

1.7.3. Vizuālo analogu skalas ............................................................... 42

1.7.4. Aptaujas ............................................................................... 43 
2. MATERIĀLS UN METODES ................................................................. 45

2.1. Pẹtījuma dizains ....................................................................................... 45

2.2. Pētījuma ētiskie aspekti .............................................................................. 45

2.3. Pētijjuma kopa ..................................................................................... 45

2.4. Metodes apraksts deguna estētikas noteikšanai 2D fotoattēlos ................... 47

2.5. Elpošanas funkcijas metodes apraksts ..................................................... 50

2.6. 3D stereo-fotogrammetrijas metodes apraksts............................................ 51

2.7. Antropometrija....................................................................................... 51

2.8. Simetrijas indekss ................................................................................. 54

2.9. Datu statistiskā analīze .............................................................................. 54

2.10. Ķirurğiskā ārstēšana............................................................................ 55

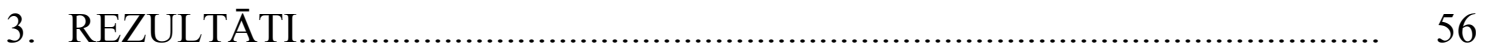

3.1. Deguna estētikas novērtēšana 2D fotoattēlos ar modificēto Anastassov un Chipkov (2003) skalu ...................................................................... 56

3.2. Deguna estētikas novērtēšana 2D fotoattēlos ar vizuālo analogu skalu ....... 59

3.3. Deguna elpošanas funkcija .................................................................... 61

3.4. Deguna un augšlūpas simetrija 3D fotoattēlos ............................................ 63

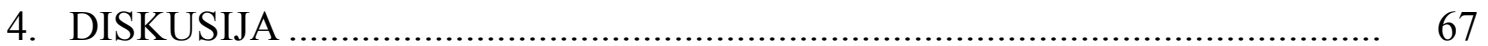

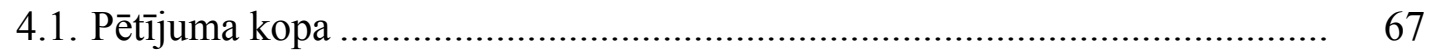

4.2. Ķirurgisiskā ārstēšana................................................................................... 69

4.3. Deguna estētikas un funkcijas novērtēšanas metodes .................................. 70

4.4. Pētījuma rezultātu interpretācija ................................................................... 74

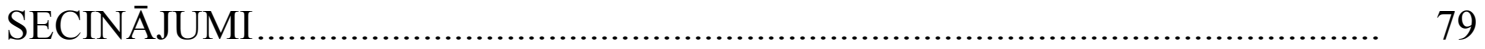

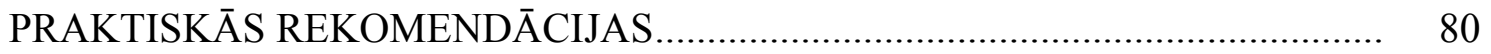

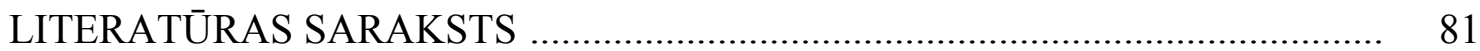

PUBLIKĀCIJAS UN ZIN̦OJUMI PAR PĒTĪJUMA TĒMU .............................. 92

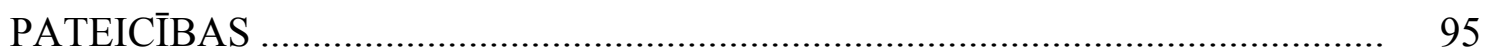

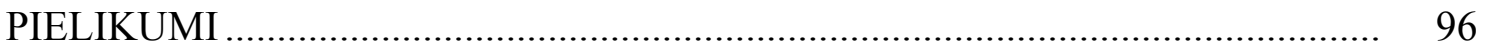




\section{DARBĀ LIETOTIE SAĪSINĀJUMI}

\begin{tabular}{|c|c|}
\hline $2 \mathrm{D}$ & divdimensiju \\
\hline $3 \mathrm{D}$ & trīsdimensiju \\
\hline $\mathrm{al}(\mathrm{L})$ & deguna spārns (kreisais) \\
\hline $\mathrm{al}(\mathrm{R})$ & deguna spārns (labais) \\
\hline alL-N & deguna sāna garums kreisajā pusē \\
\hline alL-PRN & deguna spārna garums kreisajā pusē \\
\hline alL-Sn & nāss platums kreisajā pusē \\
\hline alR-alL & deguna platums \\
\hline alR-N & deguna sāna garums labajā pusē \\
\hline alR-PRN & deguna spārna garums labajā pusē \\
\hline alR-Sn & nāss platums labajā pusē \\
\hline$A N O V A$ & analysis of variance (variāciju analīze) \\
\hline $\operatorname{ch}(\mathrm{L})$ & lūpu kaktiņš (kreisais) \\
\hline $\operatorname{ch}(\mathrm{M})$ & augšlūpa (viduspunkts) \\
\hline $\operatorname{ch}(\mathrm{M})$ lower & apakšlūpa (viduspunkts) \\
\hline $\operatorname{ch}(\mathrm{R})$ & lūpu kaktinsš (labais) \\
\hline chL-cphL & lūpas garums līdz lūpu lokam kreisajā pusē \\
\hline chR-cphR & lūpas garums līdz lūpu lokam labajā pusē \\
\hline CLCSI & Cleft Lip Component Symmetry Index (simetrijas indekss) \\
\hline $\mathrm{cm}^{3} / \mathrm{s}$ & kubikcentimetri sekundē \\
\hline $\mathrm{Cph}(\mathrm{L})$ & lūpu loka augšējais punkts (kreisais) \\
\hline $\mathrm{Cph}(\mathrm{R})$ & lūpu loka augšējais punkts (labais) \\
\hline cphL-chM & lūpas loka attālums līdz viduslīnijai kreisajā pusē \\
\hline cphR-chM & lūpas loka attālums līdz viduslīnijai labajā pusē \\
\hline$C T$ & computer tomography (datortomogrāfija) \\
\hline Dx & labā puse (latīn. dextra) \\
\hline en $(L)$ & endokants (kreisais) \\
\hline en $(M)$ & endokants (viduspunkts) \\
\hline en $(R)$ & endokants (labais) \\
\hline $\operatorname{ex}(\mathrm{L})$ & eksokants (kreisais) \\
\hline $\operatorname{ex}(\mathrm{R})$ & eksokants (labais) \\
\hline
\end{tabular}




\begin{tabular}{|c|c|}
\hline G & glabella \\
\hline $\mathrm{mm}$ & milimetri \\
\hline $\mathrm{mm}^{2}$ & kvadrātmilimetri \\
\hline $\mathrm{mm}^{3}$ & kubikmilimetri \\
\hline $\mathrm{N}$ & nasion \\
\hline NA & nav aprēķināms \\
\hline $\mathrm{nd}(\mathrm{L})$ & nāss augstākais punkts (kreisais) \\
\hline $\mathrm{nd}(\mathrm{R})$ & nāss augstākais punkts (labais) \\
\hline $\mathrm{nl}(\mathrm{L})$ & nāss zemākais punkts (kreisais) \\
\hline $\mathrm{nl}(\mathrm{R})$ & nāss zemākais punkts (labais) \\
\hline nlL-ndL & nāss augstums kreisajā pusē \\
\hline nlR-ndR & nāss augstums labajā pusē \\
\hline $\mathrm{p}$ & statistiskās ticamības līmenis \\
\hline PSKUS & Paula Stradiņa Klīniskā universitātes slimnīca \\
\hline $\mathrm{Pa}$ & paskāli \\
\hline PRN & pronasale \\
\hline PRN-N & deguna muguriņas garums \\
\hline PRN-Sn & deguna augstums \\
\hline RSU & Rīgas Stradiņa universitāte \\
\hline $\operatorname{Sbal}(\mathrm{L})$ & deguna spārna apakšējais punkts (kreisais) \\
\hline $\operatorname{Sbal}(\mathrm{R})$ & deguna spārna apakšējais punkts (labais) \\
\hline SbalL-cphL & baltās lūpas garums kreisajā pusē \\
\hline SbalR-cphR & baltās lūpas garums labajā pusē \\
\hline SbalR-SbalL & deguna pamatnes platums \\
\hline $\mathrm{SD}$ & standartdeviācija \\
\hline SI & Stomatologijas institūts \\
\hline $\operatorname{Sin}$ & kreisā puse (latīn. sinistra) \\
\hline $\mathrm{Sn}$ & subnasale \\
\hline $\mathrm{Sn} 0(\mathrm{~L})$ & kolumellas pamatne (kreisā puse) \\
\hline $\mathrm{Sn} 0(\mathrm{R})$ & kolumellas pamatne (labā puse) \\
\hline VAS & vizuālo analogu skala \\
\hline
\end{tabular}




\section{IEVADS}

Lūpu un aukslēju šķeltnes ir biežākā iedzimtā patologija sejas un žokḷu rajonā. Tā izraisa ievērojamus estētiskus traucējumus un ir iemesls smagām funkcionālām novirzēm, kas jau pirmajās dzīvības dienās un gados negatīvi ietekmē bērna fizisko un garīgo attīstību (Barkāne, 1997). Latvijā iedzimtu šķeltņu biežums no 1960. līdz 1997. gadam vidēji bija 1,2 uz 1000 dzīvi dzimušajiem bērniem ar svārstībām starp gadiem no 0,7 līdz 1,6 uz 1000 dzīvi dzimušajiem bērniem (Akota u. c., 2001). Kopš 2000. gadā ir sākta datu elektroniskā uzskaite, ir novērots, ka iedzimtu šķeltņu biežuma koeficients ir palielinājies līdz 1,4 uz 1000 dzīvi dzimušajiem bērniem (Rīgas Stradiṇa universitātes Stomatoloǵijas institūta Lūpu, aukslēju un sejas šḳeltṇu centra dati). Vidēji Eiropā iedzimtu šķeltņu biežums svārstās no 1,4 līdz 2 uz 1000 dzīvi dzimušajiem bērniem (Peterka et al., 2000). Bērnus ar šķeltnēm ārstē multidisciplināra komanda ar mērķi uzlabot estētiku, funkciju un augšanu (Maulina et al., 2007).

Vienpusējas caurejošas lūpas, alveolārā izauguma un aukslēju šķeltnes gadījumā vienmēr novēro arī deguna deformāciju. Tās nozīmīgākie iemesli ir deguna spārna skrimšlu pārvietojums, deguna starpsienas un apakšējās deguna kaulainās daḷas nepareiza pozīcija (skat. 1. att.) (Kim et al., 2004).

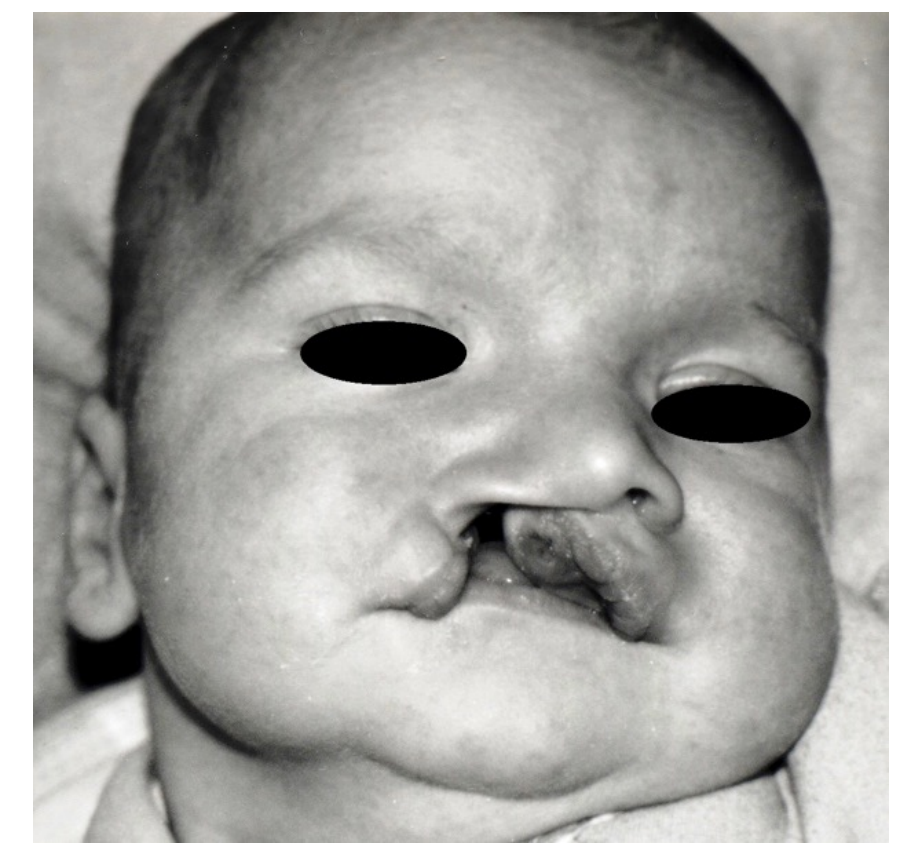

1. att. Bērns viena mēneša vecumā ar iedzimtu vienpusēju caurejošu lūpas, alveolārā izauguma un aukslēju škşeltni

(Lūpu, aukslēju un sejas šķeltņu centra foto arhīvs) 
Vēsturiski deguna deformācijas korekcija bērniem ar šķeltnēm tika atlikta līdz deguna augšana bija pilnībā beigusies. Agrīna ķirurǵiska korekcija tika uzskatīta par iejaukšanos normālā augšanā, ilgtermiņā izraisot sliktus rezultātus (Torre et al., 2000). Pēdējo 20 gadu laikā notikusi lēna filozofijas maiņa par deguna deformācijas korekcijas apjomu un laiku bērniem ar šķeltnēm. Pašlaik arvien populārāks kḷuvis uzskats par deguna deformācijas korekciju primārās lūpas plastikas laikā (Byrd \& Salomon, 2000). Kaut arī š̄i operācija samazina psiholoǵiskas problēmas, tā neizslēdz deguna deformāciju nākotnē un nepieciešamību pēc atkārtotas korekcijas (Guyuron, 2008). Savukārt sekundāra deguna korekcija ievērojami atšksiras tiem bērniem, kuriem nav bijusi primāra deguna korekcija (Ahuja, 2002).

Tā kā deguns ir novietots sejas centrālajā daḷā, tā izskatam ir ievērojama ietekme kopējā sejas estētikā (He et al., 2009b). Deguna deformācija var būt no gandrīz nepamanāmai līdz katastrofālai, kuru nosaka šķeltnes veids un smaguma pakāpe (van Loon et al., 2010). Ievērojama deguna deformācija var izraisīt psihologiskas problēmas jau bērnībā, tāpēc Gosain un Fathi (2009) uzskata, ka sekundāra deguna korekcija pie vienpusējas caurejošas lūpas, alveolārā izauguma un aukslēju škseltnes bieži ir indicēta bērniem pirmsskolas vecumā (6-8 gadi) (Gosain \& Fathi, 2009).

Deguna operāciju klīnisko rezultātu novērtējums ir komplicēts tā sarežgìitās trīsdimensionālās uzbūves dēḷ (Nolst Trenité et al., 1997). Deguna estētikas objektīvai un kvantitatīvai novērtēšanai līdz šim nav aprakstītas vispāratzītas vienotas metodes (Russell et al., 2001). Diskusijas par deguna estētikas novērtēšanas metodēm pacientiem ar lūpu un aukslēju šķeltnēm joprojām ir aktuālas. Literatūrā atrodams daudz dažādu deguna estētikas novērtēšanas metožu. Al-Omari ar kolēǵiem (2005), veicot literatūras analīzi, secinājis, lai arī nav nevienas absolūti ticamas metodes, ar kuru varētu novērtēt deguna estētiku, tomēr tās novērtēšana trīsdimensiju (3D) fotoattēlos bija ar visaugstāko ticamību. Tomēr pētījumos visbiežāk tika izmantota deguna estētikas novērtēšana divdimensiju (2D) fotoattēlos, jo metode bija vienkārša, ilgstoši lietota, ar lielu datubāzi, plaši pieejama un ērti lietojama. Tāpat nav noteikti vispāratzīti mērāmie parametri, pēc kuriem noteikt deguna estētiku. Literatūrā atrodami dažādi mērāmie parametri, lai aprakstītu sejas un deguna morfologiju, sākot no detalizētiem antropometriskiem mērījumiem, dažādām graduētām skalām līdz vienkāršām aptaujām.

Latvijā pētîjums par lūpu un deguna ķirurǵiskas ārstēšanas rezultātu novērtējumu pacientiem ar iedzimtām škseltnēm tika veikts 1968. gadā, kad Rīgas Stradiṇa universitātes (RSU) docente Biruta Barkāne bija aizstāvējusi disertāciju "Deguna un lūpas vēlīnu deformāciju ķ̧irurǵiska ārstēšana sejas šķeltņu gadījumos”. Viens no š̄̄ darba mērķiem bija novērtēt lūpas un deguna vēlīnas deformācijas pacientiem ar dažādiem šķeltņu veidiem, kuri operēti no 1900. līdz 1964. gadam (Баркане, 1968). 
Pētījumi par iedzimtām sejas šķeltnēm joprojām ir aktuāli, jo nav vienotas pieejas par šādu deformāciju korekcijas laikiem un metodiku, lai panāktu gan labu funkcionālu, gan estētisku rezultātu. Svarīga ir arī vēlīno rezultātu novērtēšana, kas prasa vairākus gadus, lai tiktu iegūta pietiekami liela pacientu grupa datu statistiskai apstrādei. Lai varētu novērtēt deguna un augšlūpas estētiku un deguna elpošanas funkciju bērniem ar vienpusēju caurejošu lūpas, alveolārā izauguma un aukslēju šķeltni, nepieciešamas objektīvas un ērti lietojamas metodes, ar kurām varētu kvalitatīvi un kvantitatīvi noteikt ārstēšanas rezultātus.

\section{Darba mērksis}

Izpētīt deguna un augšlūpas estētiku un deguna elpošanas funkciju bērniem ar vienpusēju caurejošu lūpas, alveolārā izauguma un aukslēju šķeltni, kas ārstēti RSU Stomatolog̣ijas institūta (SI) Lūpu, aukslēju un sejas šķeltņu centrā. Pamatojoties uz iegūtajiem rezultātiem, izstrādāt klīniskas rekomendācijas praktiskajā mutes, sejas un žokḷu ķirurğijā.

\section{Darba uzdevumi}

1. Novērtēt deguna estētiku bērniem ar vienpusēju caurejošu lūpas, alveolārā izauguma un aukslēju škseltni pēc lūpas un deguna plastikas divdimensiju (2D) fotoattēlos ar pielāgoto un modificēto Anastassov un Chipkov (2003) izstrādāto vērtēšanas metodi.

2. Novērtēt deguna estētiku bērniem ar vienpusēju caurejošu lūpas, alveolārā izauguma un aukslēju šķeltni pēc lūpas un deguna plastikas 2D fotoattēlos, izmantojot vizuālo analogu skalu (VAS).

3. Noteikt elpošanas funkciju bērniem ar vienpusēju caurejošu lūpas, alveolārā izauguma un aukslēju škseltni (pētījuma grupa) pēc lūpas un deguna plastikas, salīdzinot ar kontroles grupu.

4. Izmērīt deguna un augšlūpas simetriju trīsdimensiju (3D) fotoattēlos bērniem ar vienpusēju caurejošu lūpas, alveolārā izauguma un aukslēju šķeltni (pētījuma grupa) pēc lūpas un deguna plastikas un salīdzināt ar kontroles grupu.

5. Izstrādāt klīniskas rekomendācijas bērnu ar vienpusējām caurejošām lūpas, alveolārā izauguma un aukslēju škseltnēm aprūpei. 


\section{Darba hipotēzes}

1. Mazām pētījuma grupām deguna estētikas novērtēšana 2D fotoattēlos ir variabla, bet 3D fotoattēlos pietiekami objektīva.

2. Deguna plastika bērniem ar vienpusēju caurejošu lūpas, alveolārā izauguma un aukslēju šķeltni pirmsskolas vecumā nodrošina gan deguna elpošanas funkciju, gan deguna simetriju.

\section{Darba zinātniskā novitāte un praktiskā vērtība}

Latvijā pacientiem ar vienpusēju caurejošu lūpas, alveolārā izauguma un aukslēju šķeltni līdz šim nebija novērtēta deguna estētika un deguna elpošanas funkcija pēc ķirurğiskas ārstēšanas.

Darba pirmajā daḷā izmantota modificēta Anastassov un Chipkov (2003) detalizēta klīniska vērtēšanas skala, kura pētījumā pielāgota deguna estētiskai novērtēšanai divdimensiju fotoattēlos. Pētījuma otrajā daļā veikta estētikas un funkcijas kompleksa novērtēšana, lietojot gan inovatīvu aparatūru un metodi deguna un augšlūpas simetrijas novērtēšanai trīsdimensiju fotoattēlos, gan deguna elpošanas funkcijas noteikšanu ar priekšēju rinomanometriju. Pirmo reizi Latvijā bērnu ar iedzimtu vienpusēju caurejošu lūpas, alveolārā izauguma un aukslēju šķeltni ķirurğiskas ārstēšanas rezultāti salīdzināti ar veseliem bērniem (kontroles grupu).

Lai regulāri noteiktā bērna vecumā varētu ticami novērtēt gan estētiskos, gan funkcionālos ārstēšanas rezultātus pacientiem ar iedzimtu vienpusēju caurejošu lūpas, alveolārā izauguma un aukslēju šķeltni, klīniskajā praksē nepieciešams ieviest jaunas objektīvas metodes. 


\section{LITERATŪRAS APSKATS}

\subsection{Vienpusējas caurejošas lūpas, alveolārā izauguma un aukslēju škseltnes klīniskā anatomija}

Šobrīd joprojām nav pilnībā izprasts lūpas šķeltnes veidošanās mehānisms. To etioloğija ir kompleksa un ietver gan genētiskos, gan ārējās vides faktorus (Krasone et al., 2014). Embriologiski seja sāk attīstīties 4. grūtniecības nedēḷā. Pētījumos aprakstīts, ka lūpas šķeltne rodas, kad izveidojas defekts starp epiteliālo un mezenhimālo savienojumu saplūšanas stadijā (Jones \& Tatum, 2008). Vienpusējas lūpas šķeltnes variācijas ir plašas - no slēptas līdz caurejošai, kas var būt gan šaura, gan plata (Jones \& Tatum, 2008). Augšanas rezultātā notiek audu ekspansija, kā rezultātā šķeltnes smaguma pakāpe palielinās (Carstens, 1999). Vairāki autori ir sīki aprakstījuši vienpusējas caurejošas lūpas, alveolārā izauguma un aukslēju šķeltnes deguna deformācijas raksturojošās anatomiskās pazīmes, piemēram, Millard Jr (1976), Carstens (1999), Dutton un Bumsted (2001), Shih un Sykes (2002) un citi.

Jau 1976. gadā Milards Juniors ir detalizēti aprakstījis un ilustrējis vienpusējas caurejošas lūpas, alveolārā izauguma un aukslēju šķeltnes anatomiju (skat. 1.1. att.).

1. Pamatne. Ja deguna pamatnē ir šķeltne, tad vienmēr deguns būs šķ̄ibs, jo ir premaksillas projekcija ar rotāciju uz ārpusi un augšžokḷa laterālā elementa retro pozīcija.

2. Starpsiena. Augšžokḷa mediālais elements uz priekšu un laterālais elements uz aizmuguri rada izlocītu un slīpu (šķību) starpsienu. Priekšējā starpsienas daļa izliecas pār šķeltni kā nojume, kur apakšējā mala ir ārpus vomer rievas un pie spina nasalis anterior normālās nāss pamatnē. Šì deformācija ir degungala sagriešanās iemesls.

3. Deguna kauli. Augšžokḷa un premaksillas asimetrija un starpsienas deviācija rada arī deguna kaulu izkroplojumu.

4. Kolumella. Tā ir novirzīta starpsienas deviācijas dēḷ. Kolumellas vertikālais augstums ir saīsināts škseltnes pusē.

5. Deguna pamatne. Pie caurejošas šķeltnes deguna grīda ir šķeltne un augšžokļa elementi var veidot pārklājošu balstu ar spraugu no dažiem milimetriem līdz centimetriem.

6. Apakšējais laterālais spārna skrimslis. Šķeltnes puses deformētais deguna spārna skrimslis ir pārvietots no savas pozīcijas un savienojas ar degungala kupolu. Tā mediālās kājiņas kolumellā ir novietotas zemāk. Mediālās un laterālās kājinas savienojuma izliekums ir atdalîts no pretējās puses deguna spārna skrimšla un novietots zemāk, saplacināts un stiepjas pāri šķeltnei nedabīgā leņķ̄i. 
7. Deguna spārna kroka. Šķeltnes pusē deguna spārna krokai nav deguna spārna skrimšḷa izliekuma, kas nodrošina tās ceḷu. Tā turpinās slīpi pāri degungalam nedaudz laterāli līdz kolumellas un spārna malas savienojumam. Šāda deguna spārna krokas nepareiza pagarināšanās pāri degungalam šķeltnes pusē rada saraustītu degungala efektu un bieži rada deguna spārna malas deformāciju.

8. Deguna spārna pamatne. Deguna spārna pamatne ir nemainīgi rotēta uz ārpusi kā liesma. Tās apjoms var būt platāks, ar gropi, izvērsts uz āru, dažādos veidos nepareizas formas, kas ievērojami apgrūtina tās korekciju.

9. Deguna spārna mala. Deguna spārna malā vienmēr ir tikai āda, bez skrimšļa, kas krīt pāri spārna malai un saīsina kolumellas garumu šķeltnes pusē.

10. Deguna ejas g̣̣otāda. Deguna ejas gḷotāda rada iespaidu, ka ir izpletusies lielākā laukumā nekā veselajā pusē ar izgriešanos uz ārpusi spārna pamatnes rajonā. Savukārt mediālā dạ̦ā, rajonā pie starpsienas piestiprināšanās degungalam, gḷotāda ir ļoti īsa. Šāds gḷotādas iztrūkums var radīt krokojumu deguna korekcijas laikā (Millard Jr, 1976).

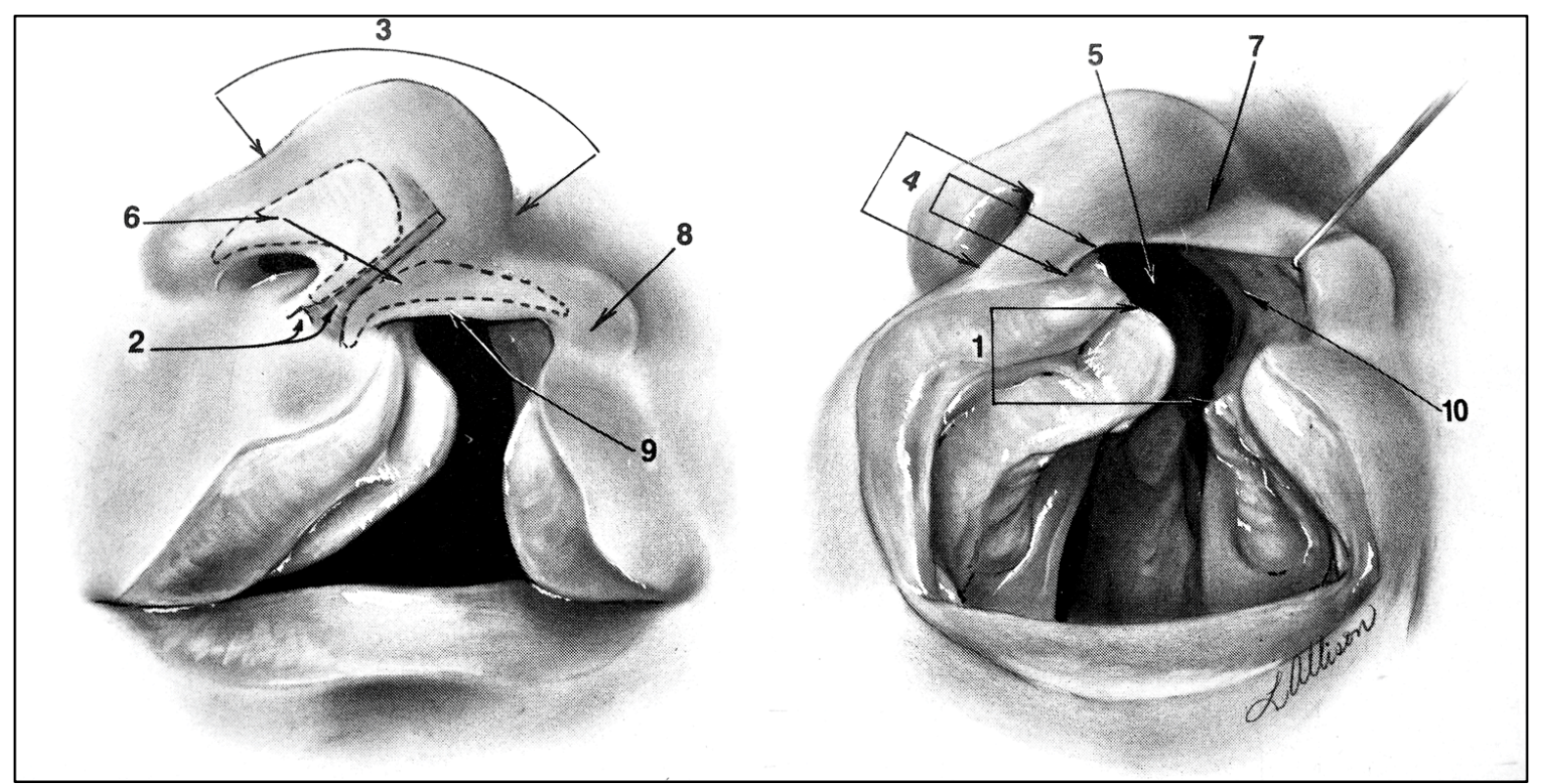

1.1. att. Vienpusēja lūpas, alveolārā izauguma un aukslēju šķeltne ar tipisku deguna deformāciju (Millard Jr, 1976)

1 - šķeltnes pamatne, 2 - starpsiena, 3 - deguna kauli, 4 - kolumella, 5 - deguna pamatne, 6 - apakšējais laterālais spārna skrimslis, 7 - deguna spārna kroka, 8 - deguna spārna pamatne, 9 - deguna spārna mala, 10 - deguna ejas gḷotāda 
Karstena (1999) veiktais vienpusējas lūpas šķeltnes deguna deformācijas anatomisko pazīmju formulējums nedaudz atšksiras no Millard Jr (1976) apraksta. Pēc Karstena (1999) domām, galveno pazīmju apkopojums ir šāds:

1. Kaula deficīts cietajās aukslējās.

2. Retrogrādi novietots un hipoplastisks augšžokḷa "plaukts".

3. Premaksillas rotācija un pārvietojums ne šķeltnes pusē.

4. Starpsienas deviācija uz ne šķeltnes pusi.

5. Abpusējs sejas vidējās zonas mīksto audu centrbēdzes "lidojums" periosta līmenī.

6. Gḷotādas pārklājuma absolūts iztrūkums.

7. Deguna spārna pamatnes deformācija šķeltnes pusē, pa x asi tā novietota laterāli, pa y asi ir ārēja rotācija, pa z asi ir kaudāla rotācija.

8. Deguna spārna skrimšla deformācija šķeltnes pusē. Nepareizs leņķis starp mediālajām un laterālajām kājiņām, mīksto audu piesaistes dēl pie ierobežotā deguna spārna un starpsienas deviācijas. Kolumellas pseidosaīsināšanās, kas izveido nāss kupola ieplaku. Laterālās kājiņas izliekšanās pa viduslīniju, nepietiekošā gḷotādas pārklājuma dēḷ.

9. Vestibulārs tīklojums ārējās ādas un pārejas krokas neatbilstības dēḷ.

10. Sekundāra kolumellas deformācija uz ne škseltnes pusi. Kolumellas pamatne ir novietota laterāli no viduslīnijas. Kolumellas piestiprinājums šķeltnes pusē ir paslēpts nāss ejā, augstums ir pseidosaīsināts attiecībā pret ne škseltnes pusi (Carstens, 1999).

Kopumā vienpusējas caurejošas lūpas, alveolārā izauguma un aukslēju šķeltnes izskats ir savdabīgs, uzmanību piesaistošs un patognoms tieši šai iedzimtajai patologijai (Millard $J r$, 1976). Rinoplastika pie vienpusējas caurejošas lūpas, alveolārā izauguma un aukslēju šķeltnes deguna deformācijas joprojām ir izaicinājums šķelțu ķirurgiem, jo tā ir sarežğîta trīsdimensionāla deformācija, kas skar ādu, skrimsli, gḷotādu un kaulu struktūras. Ir nepieciešamas perfektas zināšanas šķeltnes patologiiskajā anatomijā un tās izprašana, lai sasniegtu apmierinošus estētiskus un funkcionālus rezultātus (Shih \& Sykes, 2002). 


\subsection{Vēsturisks ieskats par pacientu vecumu deguna koriǵējošām operācijām}

"Neaiztikt degunu pie primāras vienpusējas lūpas un aukslēju šķeltnes ķirurǵijas!” Pagātnē šī dogmatiskā attieksme bērniem izraisīja funkcionālas un estētiskas (psihologiskas) problēmas (Anderl et al., 2008). Vēsturiski šķeltņu deguna deformācijas korekcija tika novēlota līdz deguna augšana bija pilnībā beigusies. Agrīna ķirurǵiska korekcija tika uzskatīta kā iejaukšanās normālā augšanā, ilgtermiņā izraisot sliktus rezultātus (Torre et al., 2000). Vieni no pirmajiem, kas pievērsās deguna deformācijas pazīmēm pie šķeltnēm bija Blair un Brown 1931. gadā. Savukārt 1966. gadā Gillies un Millard (Guyuron, 2008) apgalvoja, ka deguna deformācijas korekcija reizē ar lūpas korekciju nav mērķtiecīga, jo deformācija ir ļoti kompleksa. Viņi secināja, kaut arī deguna deformāciju veiksmīgi koriğē primāras lūpas plastikas laikā, nākotnē vienalga būs nepieciešama operācija. Aufricht apgalvoja, ka deguna deformācijas korekcija būtu jāatliek līdz 16, 17 gadu vecumam (Guyuron, 2008). Pagājušā gadsimta piecdesmitajos gados ķirurgi sāka koriǵēt deguna deformācijas nelielas pazīmes un tā turpinot arvien radikālākas deguna deformācijas korekcijas (Anderl et al., 2008).

Pēdējo 20 gadu laikā notikusi lēna filozofijas maiņa par šķeltņu deguna deformācijas korekcijas apjomu un laiku. Pašlaik arvien populārāks kḷuvis uzskats par deguna deformācijas korekciju pie škseltnēm agrīnā vecumā, visbiežāk primāras lūpas plastikas laikā. McComb un Coghlan (1996) ar saviem ilgtermiņa pētījumu rezultātiem parādījuši, ka primāra deguna korekcija neietekmē skrimšla augšanu. Tāpat arī Anderl, Salyer un citi (Byrd \& Salomon, 2000) to ir pierādījuši. Agrīna deguna ķirurğiska korekcija rada simetriskāku skrimšļu augšanu (Byrd \& Salomon, 2000). Kobus 1987. gadā (Torre et al., 2000), lai korig̣ētu deguna deformāciju šķeltnes gadījumā, sāka lietot plašu preparēšanu un apakšèjā laterālā skrimšļa superiomediālu pacelšanu ar deguna caurulīti un dažādām fiksējošām šuvēm bērniem jau 6 mēnešu vecumā (Torre et al., 2000).

Šodien lielākā daļa deguna deformāciju korekcijas tiek veiktas primāras lūpas plastikas laikā. Kaut arī šî operācija samazina psiholoǵiskas problēmas, tā neizslēdz deguna deformāciju nākotnē un nepieciešamību pēc atkārtotas korekcijas (Guyuron, 2008).

\subsection{Primāra deguna plastika}

Primāra deguna plastika tika apspriesta jau starp Barkeley (1959), Millard (1982), McComb (1985), Green (1987), Sadove (1988) (Sugihara et al., 1993). Galvenie iemesli sliktiem rezultātiem bija aizkavēta augšžokḷa attīstība un atgriezeniska deguna deformācija. Šādus augšanas traucējumus saistīja ar ķirurǵisku iejaukšanos agrīnā vecumā (Sugihara et al., 
1993). Pastāv dažādi uzskati par ķirurğijas laiku un tehnikām vienpusējas caurejošas lūpas, alveolārā izauguma un aukslēju šķeltnes deguna deformācijas gadījumā. Pie primāras deguna korekcijas, deguns nav pietiekoši liels ķirurğijai un skrimslis nav nobriedis. Šo iemeslu dēl ķirurǵijas tehnikas ir grūtas un nav viennozīmīgu rezultātu. Kā arī joprojām nav skaidra primāras ķirurğijas ietekme uz skrimšļa tālāku attīstību. Sugihara ar kolēǵiem (1993) savā darbā uzsver, ka tikai lūpas korekcijas laikā ir relatîvi plaša pieeja ķirurǵijai deguna dobumā (Sugihara et al., 1993). Ir aprakstītas daudzas tehnikas, lai atrisinātu šo problēmu, kas norāda, ka nav ideālas procedūras (Gubisch, 1995). Deguna deformācija pie vienpusējas caurejošas lūpas, alveolārā izauguma un aukslēju šķeltnes ir sarežǵḡta un kompleksa anatomiska anomālija, tās korekcija nav vienkārša vienreizēja procedūra (Foda \& Bassyouni, 2000).

Galvenie deformācijas komponenti ir šķeltnes pusē kaudāli un uz leju novietots apakšējais laterālais skrimslis, nāss velves asimetrija, deguna spārna saplacināšanās, kolumellas saīsināšanās šķeltnes pusē un hipoplastiska kaula platforma deguna spārna pamatā šķeltnes pusē (skat. 1.2 att.) (Anderl et al., 2008).

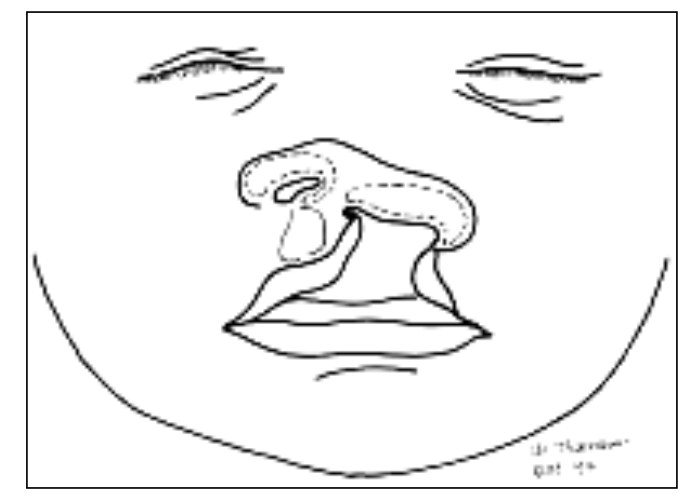

1.2. att. Mākslinieka attēlota deguna deformācija pacientam ar vienpusēju caurejošu lūpas, alveolārā izauguma un aukslēju šķeltni (Anderl et al., 2008)

Kaut arī deguna un lūpas korekciju veic vienlaicīgi, to nevajadzētu uzskatīt kā papildinājumu pie primāras lūpas plastikas, bet gan kā atsevišķu procedūru ar tam atšķirīgu pieeju un uzdevumiem. Pēc Byrd un Salomon (2000) domām, galvenie atslēgas elementi pie primāras šķeltṇu rinoplastikas ir izveidot normālu izliekumu laterālajam skrimslim, palielināt nāss velves projekciju šķeltnes pusē, pārvietot deguna spārna pamatu un izveidot augšžokļa platformu skartajā pusē (Byrd \& Salomon, 2000). Savukārt Salyer (1992) norāda daudz plašākus primāras lūpas šķeltnes un deguna korekcijas mērķus. Viņa izvirzītie mērķi ir radīt līdzsvarotu, simetrisku lūpu un normāla izskata degunu. Ir nepieciešamas daudzas ķirurgisiskas procedūras, lai iegūtu labus rezultātus. Vienas no svarīgākajām procedūrām ir slēgt deguna pamatu, sasniegt deguna spārna un nāsu kupola simetriju abās pusēs, sasniegt simetrisku 
degungala projekciju, pārveidot apakšējo laterālo skrimsli, pagarināt kolumellu šķeltnes pusē, iztaisnot kolumellu un sasniegt nāsu atveres ekvivalentu ar ne šķeltnes pusi (Salyer, 1992). Pēc Kane ar kolēgiem (2000) domām, agrīna deguna deformācijas korekcija un alveolārā kaula transplantācija var samazināt sekundārās deformācijas smagumu un dažiem pacientiem pat var pietikt ar primāru korekciju.

\subsubsection{Primāras deguna plastikas korekcijas laiki}

Mūsdienās lielākā daļa deguna deformāciju korekcijas tiek veiktas primāras lūpas plastikas laikā (Guyuron, 2008). Anderl ar kolēgiem (2008) uzskata, ka optimālais bērna vecums šai operācijai ir starp 5 un 6 mēnešiem. Vecāki jābrīdina, ka pārāk agra ķirurğija nedos labu rezultātu bērnam (Anderl et al., 2008). Savukārt Torre ar kolẹgiem (2000) norāda, ka vidējais bērna vecums ķirurğijai ir 2-4 mēneši. Latvijā bērniem ar vienpusēju caurejošu lūpas, alveolārā izauguma un aukslēju šķeltni primāru lūpas plastiku veic 3-6 mēnešu vecumā vienlaicīgi ar deguna formas korekciju (Shaw et al., 2001).

\subsubsection{Nazoalveolārās platītes lietošanas lietderīgums}

Pastāv dažādi uzskati par nazoalveolārās platītes lietderīgumu. Vairāki autori uzskata, ka tā ir vērtīga, ievērojami uzlabo deguna formu un atvieglo ķirurgam veikt primāru lūpas un deguna plastiku. Cho (2006) norāda, ka nazoalveolāra platīte ir papildus terapija, lai atvieglotu primāru lūpas un deguna korekciju, bet tā noteikti nav vien̄̄gā deguna asimetrijas ārstēšana pacientiem ar šķeltni (Cho, 2006). Pie vienpusējas caurejošas lūpas, alveolārā izauguma un aukslēju šķeltnes transalveolāra deguna ekstensija ar ekspansijas ierīcēm kalpo, lai paceltu un veidotu deguna spārna laterālās kājiņas skartajā pusē. Ar šo pacelšanas tehniku var panākt deguna spārna rievas izliekuma korekciju. Tomēr laterāla atbrīvošana un ķirurǵiska skrimšḷa repozīìja joprojām ir nepieciešama (Byrd \& Salomon, 2000) (skat. 1.3. att.).
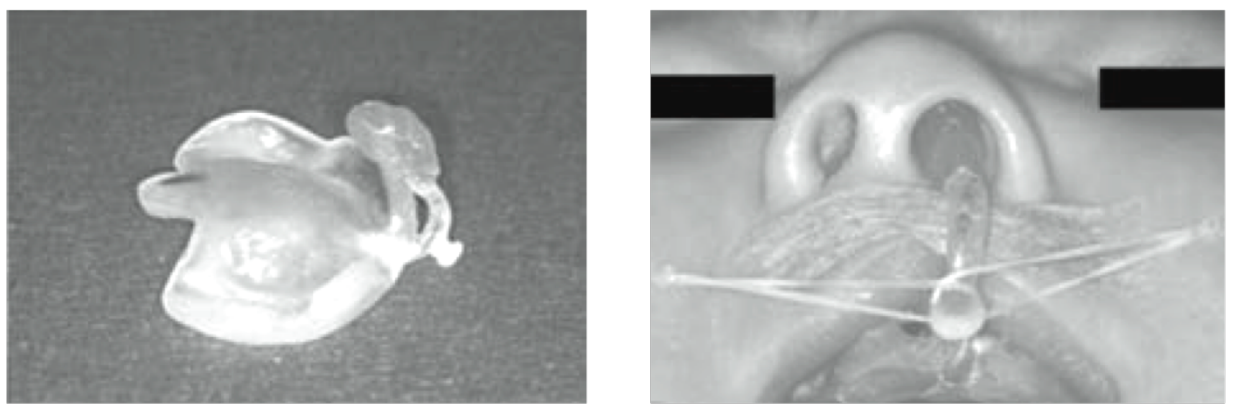

1.3. att. Nazoalveolārā platīte un tās pielietojums pacientam (Isogawa et al., 2010) 
Teorija par pirms ķirurgisku nazoalveolārās platītes ārstēšanu balstās uz Matsuo pētījumiem, ka deguna skrimslis joprojām attīstās un pakḷaujas repozīcijai pirmajās 6 dzīves nedēḷās (Matsuo \& Hirose, 1991). Ir daudz ziņojumu par pirms ķirurǵgisku nazoalveolārās platītes efektivitāti pacientiem ar vienpusēju caurejošu lūpas, alveolārā izauguma un aukslēju škseltni (Maull et al., 1999; Grayson et al., 1999; Grayson \& Cutting, 2001; Liou et al., 2004; Ezzat et al., 2007). Vidējais vecums, kādā bērniem liek pirms ķirurğisku nazoalveolāro platīti, ir 26 dienas un vidējais terapijas garums 110 dienas. Ezzat ar kolēgiem (2007) konstatēja, ka pirms ķirurgíjas nazoalveolārā platīte uzlabo deguna simetriju un palīidz normalizēt dentoalveolāro loku (Ezzat et al., 2007). Arī Liou ar kolēgeiem (2004) secinājis, ka pirms ķirurǵijas nazoalveolārā platīte ievērojami uzlabo deguna simetriju, šī simetrija agrā bērnībā saglabājas pietiekoši ilgi. Tomēr ilgstošas deguna simetrijas un augšanas progresējošas pārmaiņas, pirms un pēc pirms ķirurğiskās nazoalveolārās platītes procedūras un ķirurǵiskas korekcijas joprojām nav pietiekami dokumentētas (Liou et al., 2004).

Autori, kuri veikuši literatūras analīzi par nazoalveolārās platītes lietderīgumu, norādīja, ka pētījumos bija uzrādīti ierobežoti pierādījumi nazoalveolārās platītes lietderīgumam (van der Heijden et al., 2013; Abbott \& Meara, 2012; Manosudprasit et al., 2014; Sischo et al., 2015). Joprojām nav veikti ticami ilgtermiņa kontrolēti klīniskie pētījumi. Tāpat arī autori uzskata, ka nepieciešams novērtēt izmaksas, ieguvumu un pacientu vecāku spēju aprūpēt bērnus ar nazoalveolāro platīti (Manosudprasit et al., 2014). Savukārt Sischo ar kolēǵiem (2015) uzskata, ka nazoalveolārās platītes lietošana uzlabo vecāku un bērna ar iedzimtu šķeltni attiecības, palielina vecāku atbildību un pašapziņu (Sischo et al., 2015). Clark ar kolēgéiem (2011) salīdzināja lūpas un deguna estētikas rezultātus bērniem sešu gadu vecumā ar nazoalveolārās platītes lietošanu un bez tās. Rezultātus novērtēja klīniski, 3D fotoattēlos un augšžokḷa zobu rindu ǵipša veidul̦os. Autori secinājuši, ka lūpas un deguna estētikai starp grupām statistiski nozīmīgas atšķirības nebija (Clark et al., 2011). Arī van der Heijden ar kolēgiem (2013) uzskata, ka joprojām nav pierādīta nazoalveolārās platītes lietošanas pozitīvās īpašības. Šie autori veicot literatūras analīzi, saskarās ar pētījumu dizaina, rezultātu, to interpretāciju, novērošanas perioda heterogenitāti, kas apgrūtināja veikt pētījumu meta-analīzi (van der Heijden et al., 2013). Abbott un Meara (2012) secinājuši, ka par spīti tam, ka nav pierādīta nazoalveolārās platītes efektivitāte, izskatās, ka tā varētu būt daudzsološa tehnika. Joprojām ir nepieciešami pareiza dizaina ilgtermiņa klīniskie pētījumi, lai varētu nonākt pie kopsaucēja par nazoalveolārās platītes ieguvumiem salīdzinot ar citiem ārstēšanas protokoliem (Manosudprasit et al., 2014). 


\subsubsection{Primāras deguna plastikas ķirurğiskās tehnikas}

Vēsturiski, kad ķirurgi sāka koriǵēt deguna deformācijas, ķirurǵija deformētā deguna spārna rajonā bija ierobežota (Anderl et al., 2008). Šodien deguna deformācijas ķirurğija tiek veikta pēc griezieniem, kas nepieciešami lūpas korekcijai. Sugihara ar kolēǵiem (1993) savā pētījumā veica zem skrimšļa griezienu gandrīz pa visu deguna nāss priekštelpas atveri šķeltnes pusē pēc Dingman un Natvig, kas aizsākta jau 1982. gadā (Sugihara et al., 1993). Savukārt Kim ar kolēǵiem (2004) griezienu veica pēc Mulliken metodes kā pie primāras lūpas plastikas, pagarinot griezienu līdz kolumellas vidusdaļai un lūpu pagarinot lietojot „C" veida lēveri (Kim et al., 2004). Byrd un Salomon (2000) apraksta, ka Millard rotējošais - paaugstinājuma dizaina grieziens tiek lietots arī pie vienlaicīgas deguna korekcijas (skat. 1.4. att. augšā pa kreisi). Šāds grieziena veids labi atbrīvo apkārtējo muskulatūru un ļauj neatkarīgu deguna spārna pamata pārvietošanu. Muskulu slān̄̄ grieziens, apkārt deguna spārna pamatam, tiek veikts 45 grādu leņķ̄i attiecībā pret sejas plakni. Šāds grieziena slīpums pasargā muskuḷuudu kūlīti, kurš palicis saistīts ar spārna pamatu. Šo muskuḷu loma vēēāk tiek izmantota, lai atjaunotu deguna platformu (skat. 1.4. att. augšā pa labi). Pēc visiem griezieniem pie primāras lūpas plastikas un deguna gḷotādas atbrīvošanas, deguna spārns ir brīvi kustīgs (skat. 1.4. att. apakšā pa kreisi). Pilnīgu kustīgumu novērtē pārvietojot nāsu velves vienā līmenī, izmantojot neasu āķīti (skat. 1.4. att. apakšā centrā). Atpreparēti ir degungals, distāli velves vidusdaļa un abi deguna spārnu rajoni. Tonētais rajons (skat. 1.4. att. apakšā pa labi) parāda deguna subkutāno audu atbrīvošanas zonu (Byrd \& Salomon, 2000).

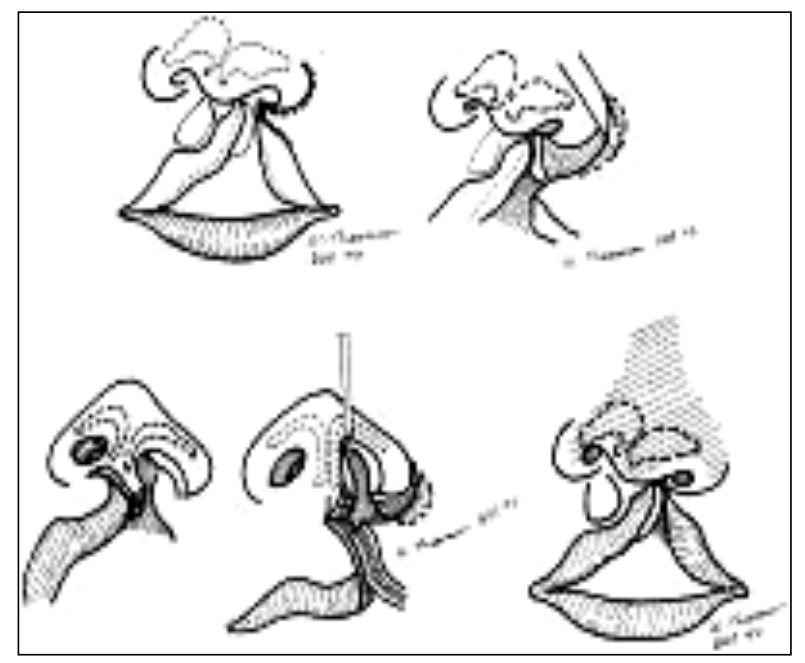

1.4. att. Shematisks Millard rotējošā- paaugstinājuma grieziena attēls (Byrd \& Salomon, 2000) 
Pēc deguna spārna skrimšḷu identifikācijas (skat. 1.5. att. augšā pa labi), ķirurgijias lauks tiek paplašināts līdz degungalam, deguna mugurai, ietverot deguna spārna skrimsli un laterālo skrimsli (skat. 1.5. att. apakšā pa kreisi). Dažos gadījumos šķeltnes pusē nav iespējams atbrīvot laterālo skrimsli ar preparēšanu vien. Deguna spārna skrimšlı̆la laterālās kājiņas pamats tiek nogriezts un atlikušais deguna dobuma gḷotādas defekts tiek slēgts ar Millard „L” veida lēveri (Sugihara et al., 1993).

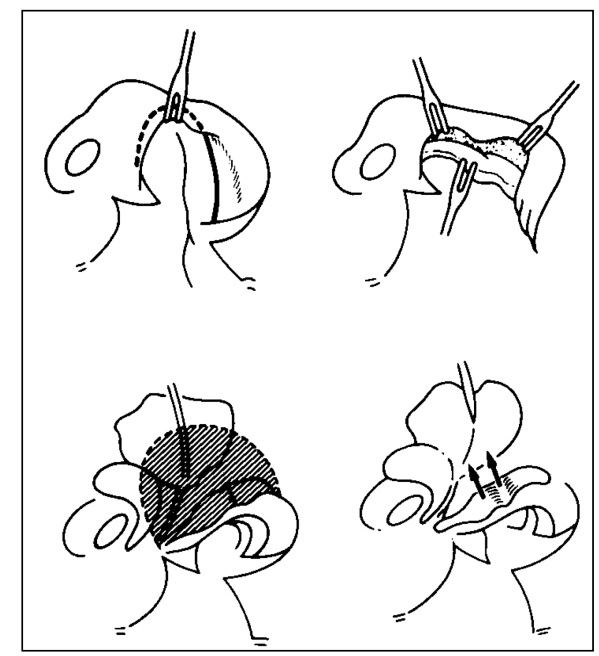

1.5. att. Shematisks primāras deguna korekcijas attēls (Sugihara et al., 1993)

Pēc Kim ar kolēgiem (2004), deguna spārna skrimslis tiek preparēts supraperihondrālā plāksnē caur kolumellas un deguna spārna malas incīzijas vietu. Pārvietotais spārna skrimslis tiek pacelts pēc modificêtās Tajima metodes ar 5-0 nylon šuvēm, pareizā hiperkoriǵētā pozīcijā (skat. 1.6. att.) (Kim et al., 2004).

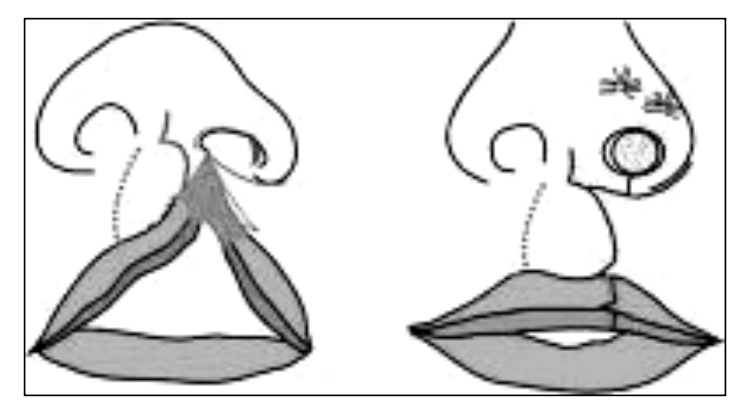

1.6. att. Shematisks pirms operācijas un pēc operācijas deguna deformācijas attēls (Kim et al., 2004)

Pēc Byrd un Salomon (2000) domām, l̦oti svarīgi, lai otrais sezamveida skrimslis arī būtu atbrīvots, lai sasniegtu nepieciešamo mobilitāti (skat. 1.4. att. apakšā centrā un pa kreisi). Tiek saglabāts normāls mediālās kājinas pamatnes piestiprinājums pie deguna smailes un 
apkārtējiem audiem. Šķeltnes pusē mediālās kājiņas pamatnes piestiprinājums tiek atbrīvots, lai pagarinātu kolumellu, kas ir arī daļa no rotācijas soḷa. Pēc deguna spārna pamata grieziena, preparēšana turpinās abās pusēs virs apakšējā un laterālā skrimšļa, lai savienotu iepriekš preparēto rajonu ar kolumellas pamatni. Pēc abu mediālo kājiņu atdalīšanas, bojātā mediālā kājiņa ir brīva un tiek pārvietota uz augšu kopā ar „C” veida lēvera rotāciju (Byrd \& Salomon, 2000).

Deguna deformācija pie vienpusējas caurejošas lūpas, alveolārā izauguma un aukslēju šķeltnes skar arī starpsienu. Tā var būt pārvietota no lemeša (vomer) rievas un var būt izliekta skrimšlainā daḷā. Kaudālā starpsienas daļa ir pārvietota virzienā prom no škseltnes un tiek novērota starpsienas mugurējās daļas deformācija (Ahuja, 2002). Starpsienas pārmaiņas veidojas, jo apakšêjā laterālā skrimšļa mediālā kājiņa ir īsāka šķeltnes pusē. Kolumella ir saīsināta, jo muskuļi, kas ieiet tās pamatnē un savienojas ar mutes gredzenmuskuli, ir nobīdījuši to uz veselo pusi (Balaji, 2003). Ilglaicīgai deguna stabilitātei un formai, lai nodrošinātu brīvus elpceļus, starpsiena ir jāpārvieto pareizā anatomiskā pozīcijā. Līdz minimumam jāsamazina atgriezeniska deviācija. Tādēḷ abās pusēs gḷotāda subperihondriāli pilnībā jāatdala no starpsienas (skat. 1.7. att.), sākot no starpsienas pamata līdz augšējā laterālā skrimšḷa galotnei un uz aizmuguri līdz kaulainajam lemesim. Ir nepieciešama lupa, lai izvairītos no skrimšla bojājuma. Pēc tam, kad starpsiena ir atbrīvota no ciešās gḷotādas un starpsienas skrimslis ir atbrīvots no cieto aukslēju kaula, tas tiek iztaisnots ar neasām knaiblēm. Pašā skrimslī griezienus neveic, kā arī to nefiksē ar diegiem. Ja starpsienas priekšējai daļai ir tendence noliekties, to var piefiksēt pie muskuļa un tā noturēt pareizā pozīcijā. Gḷotāda tiek pielikta atpakal pie skrimšḷa un uz dažām dienām tiek ievietoti marles valnīši (Anderl et al., 2008).

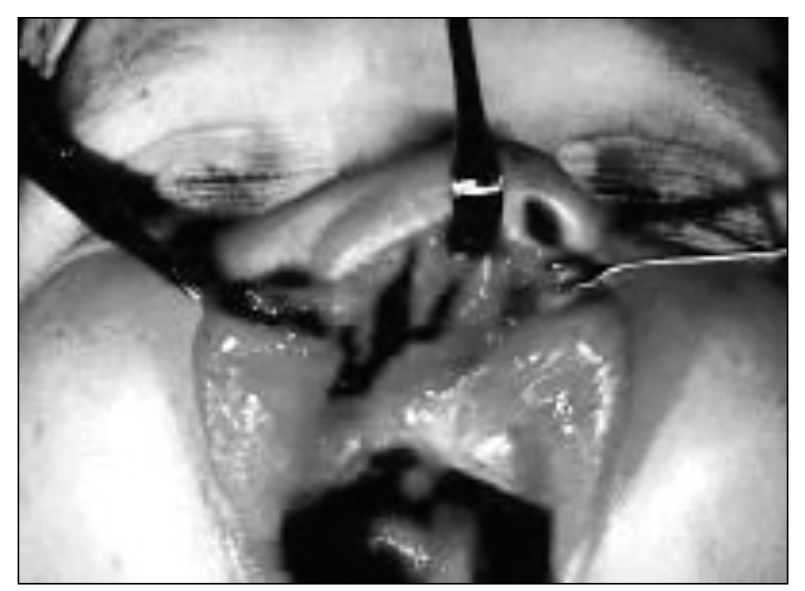

1.7. att. Operācijas laikā tiek veikta starpsienas gḷotādas preparēšana abās pusēs (Anderl et al., 2008) 


\subsection{Sekundāra deguna plastika}

Sekundāras deguna korekcijas galvenokārt fokusējas skeletālā balsta, iekšējo deformāciju un apakšèjā laterālā skrimšļa pārkārtošanā. Gala rezultātā estētisko izskatu var ievērojami uzlabot, pārveidojot deguna kontūru, pievienojot papildus skrimšļa un/ vai kaula implantus. Ķirurğiskās tehnikas izvēle ir atkarīga no deformācijas smaguma, ķirurga pieredzes un profesionalitātes. Svarīgākais ķirurgam ir pieņemt lēmumu, kuru tehniku izvēlēties katrā gadījumā. Kā arī nolemt vai izvēlēties val̦ēju, vai slēgtu pieeju. Val̦ēju pieeju iesaka gadījumos, ja ir smaga vai vidēji smaga deguna deformācija (Salyer, 1992).

\subsubsection{Sekundāras deguna plastikas korekcijas laiki}

Parasti ārsti vilcinās veikt radikālas deguna korekcijas jauniem pacientiem, jo baidās no augšanas aizkavēšanās (Thomas \& Mishra, 2000), kaut arī ir ziņojumi, ka deguna osteotomija un starpsienas rezekcija ir veiktas jauniem pacientiem bez kaitīgas ietekmes sejas attīstībā. Bardach un Salyer novēloja starpsienas korekciju un osteotomiju līdz pacients sasniedza 14 gadu vecumu un viṇi rekomendēja, ka tikai deguna spārna repozīcija var tikt veikta no 4-12 gadu vecumam (Ahuja, 2001).

Pēc Salyer (1992) domām, korekcija būtu veicama pirms bērns sāk iet skolā, jo tas palīdzētu izvairīties no bērna izsmiešanas skolā. Svarīgi saprast, ka šīs sekundārās deformācijas ir sagaidāmas gandrīz visos gadījumos, jo ir ļoti grūti sasniegt optimālus rezultātus pie visām vienpusējām lūpas, alveolārā izauguma un aukslēju šķeltnēm. Iespējams, ja deguna deformācija nav tik smaga un ir veikta primāra deguna korekcija, tālāka ķirurǵiska korekcija būs ar daudz labākiem rezultātiem. Pie sekundāras deguna korekcijas, koriǵējošā ķirurǵijā lieto dažādas manipulācijas, kuras atkarīgas no deformācijas tipa un smaguma pakāpes. Vairumā gadījumu ar deguna ārējo struktūru pārkārtošanu un pārvietošanu pietiek, bet reizēm ir nepieciešama skrimšla augmentācija. Kā arī deguna starpsienas plastika un deguna osteotomija var nodrošināt labāku funkcionālu un estētisku rezultātu (Salyer, 1992). Vaļēju degungala pieeju parasti lieto bērniem, kuriem ir vismaz 5 gadi. Ideāli šo procedūru būtu veikt, kad skrimslis ir pietiekoši nobriedis un skrimšla preparēšana var notikt netraumējot skrimšḷa vai apkārtējās deguna struktūras (Salyer, 1992). 


\subsubsection{Sekundāras deguna plastikas ķirurǵiskās tehnikas}

Vaḷēja rinoplastikas pieeja ir atzīta kā labākā pie sekundāras deguna deformācijas (Foda \& Bassyouni, 2000; Thomas \& Mishra, 2000; Torre et al., 2000). Vaḷeja rinoplastika ir svarīga ārstēšanas tehnika un tajā plaši lieto transversālu kolumellas griezienu. Tomēr, pie val̦ējas rinoplastikas, nāsu - degungala griezieni nekad nav kḷuvuši populāri, kaut arī tā var labāk korig̣èt nobīdīto nāsu priekštelpu šķeltnes pusē, pieskaņojot nāsu galus (Matsuya et al., 2003).

Vaļēju rinoplastiku var iedalīt 2 grupās pēc griezienu veida. Grieziens nāsu galā un grieziens transversāli kolumellai. Pirmā grupa ietver šādus griezienus pēc autoriem - Figi, Erich un Gelbke. Otrā grupa - Rethi, Potter, Spira, Stenstrom un Oberg, Nishimura, Goodman un Zorn, Gunter un Rohrich, Cronin un Denkler, u.c. (skat. 1.8. att.). No šiem plaši lieto Potter's griezienu (Matsuya et al., 2003).

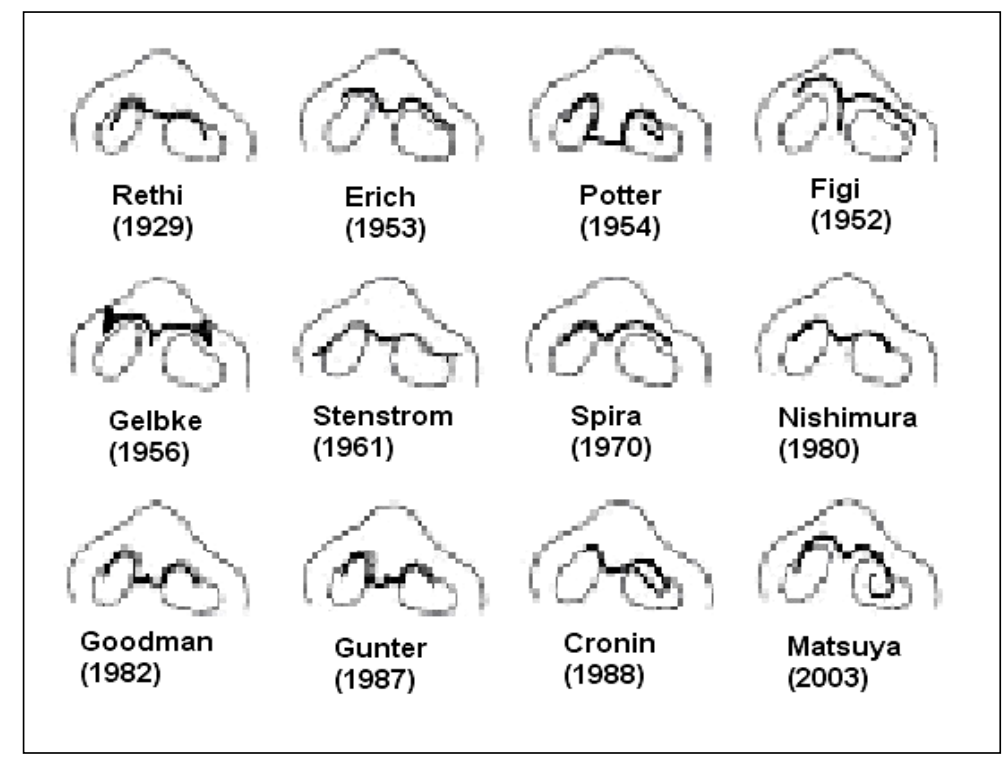

1.8. att. Shematiski vaḷējas rinoplastikas griezienu dizaini pie vienpusējas caurejošas lūpas, alveolārā izauguma un aukslēju šķeltnes (Matsuya et al., 2003)

Ja pie rinoplastikas nepieciešams pagarināt nāsu priekštelpu, plaši lieto arī „,Z” plastiku un ,V-Y” pagarināšanu laterālā priekštelpas sienā. Daži autori atbalsta laterālās kājiņas pagarināšanu un repozīciju ar mediāli veidotu hondromukozālu lēveri. Šo lēveri veido grieziens priekštelpā gar laterālo kājiņu un grieziens uz augšu pa vidu starp apakšējo un augšējo laterālo skrimsli (Matsuya et al., 2003).

Matsuya ar kolēgiem (2003) izveidoja jaunu val̦ējas rinoplastikas griezienu ,lidojošais putns" (“flying-bird"). To veic nāsu galā, pāri nāsu lokiem, ar pagarinājumu uz priekšu un uz 
leju kolumellas viduslīnijas augstākajā pozīcijā. Abi spārni iet gar deguna spārna skrimšla malu un ieiet laterālajā priekštelpas sienā. Ar ādas āķi, abas nāsu priekštelpas atveres tiek paceltas simetriski, lai noteiktu „tornado” veida grieziena lokalizāciju, kas pagarinās nāsu priekštelpas jumtu (skat. 1.9. att.) (Matsuya et al., 2003).

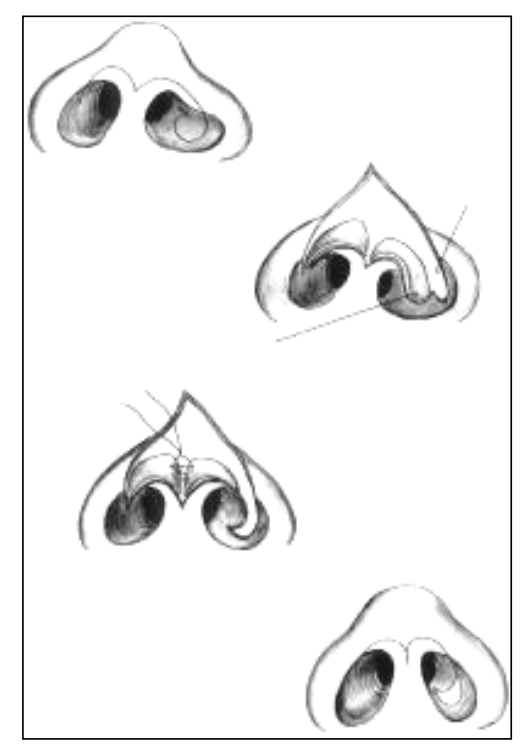

1.9. att. Shematiski attēlota vaḷēja rinoplastika, lietojot „lidojoša putna” grieziena tehniku (Matsuya et al., 2003)

Savukārt Salyer (1992) iesaka lietot modificēto Bardach's val̄ēja degungala rinoplastikas tehniku. Lietojot šo tehniku, kolumellas āda tiek atpreparēta no zemāk esošās mediālās kājiṇas līdz apakšējiem laterālajiem skrimšlıem abās pusēs. Kad ādas lēveris ir atpreparēts, to paceļot var redzēt abus laterālos skrimšlus. Pēc saistaudu un taukaudu noņemšanas, abu skrimšlı laterālās kājiņas tiek atpreparētas no zemāk esošiem audiem. Pēc tam, kad tās ir atbrīvotas, tiek izmainīta to forma, tās tiek pārvietotas, sašūtas kopā ar matračveida šuvēm un tiek izveidots jauns deguna spārnu kupols. Degungals un laterālās kājiņas tiek novietotas jaunā pozīcijā, ko slēdz ar ādas lēveri. Dažos gadījumos ir nepieciešama skrimšla augmentācija, lai sasniegtu labāku degungala projekciju vai apalāâku deguna spārna kontūru (Salyer, 1992). Arī Ahuja (2001), ja nepieciešams, palielina degungalu ar skrimšlı̆iem, kas tiek rezicēti no starpsienas vai laterālās kājiṇas.

Ļoti piesardzīgi jāapsver deguna osteotomijas nepieciešamība (Ahuja, 2001). Arī Salyer (1992) uzskata, lai sasniegtu labākus rezultātus, bieži ir nepieciešama deguna kaulu osteotomija.

Salyer (1992) pie sekundāras deguna korekcijas pārsvarā veic slēgtu rinoplastiku, pirms bērni sāk iet skolā. Bet vaḷeju rinoplastiku lieto tikai tad, ja deformācija ir plaša, lai sasniegtu optimālu rezultātu pie sekundāras vienpusējas caurejošas lūpas, alveolārā izauguma un aukslēju 
šķeltnes deguna korekcijas. Deguna gḷotāda bieži ir pārvietota vai sagriezusies un šajos gadījumos tā uzmanīgi jāatpreparē, lai varētu skrimšlıs pārvietot jaunā pozīcijā. Daudzos gadījumos, ja gl̦otādu pilnībā neatpreparē, tad pārvietotie skrimšlı li atkal deformēsies, kad ādas lēveris būs slēgts. Pārveidojot skrimšlu formu un pozīciju, jāpanāk, lai pēc ādas sašūšanas tie atkal nemainītu savu pozīciju. Slēgtas rinoplastikas gadījumā, šķeltnes pusē veic griezienu gar nāss malu. (skat. 1.10. att.) (Salyer, 1992).
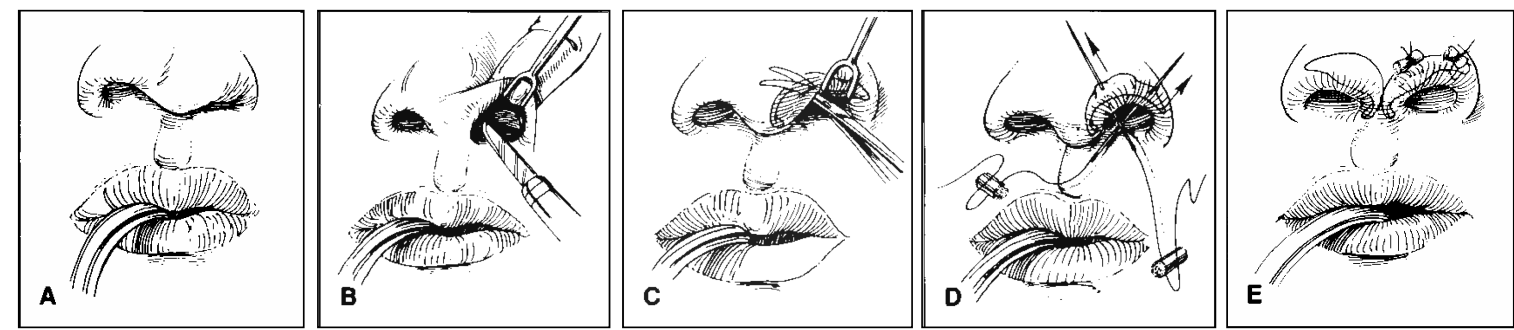

1.10. att. Shematisks slēgtas sekundāras deguna korekcijas attēls pie vienpusējas caurejošas lūpas, alveolārā izauguma un aukslēju šķeltnes (Salyer, 1992)

A - deguna deformācija, B - nāss kores grieziens priekštelpas ādā, C - ādas preparēšana, D - valnīšu pozicionēšana, E - valnīšu ievietošana

Gḷotāda tiek pilnībā atdalīta no deguna spārna skrimšḷa. Ne šķeltnes pusē ādu uzmanīgi atpreparē no apakšējā laterālā skrimšlı. Tas l̦auj atbrīvot apakšējo laterālo skrimsli šķeltnes pusē un simetriski pārvietot kā pretējā pusē. Caurejošas šuves un valnīšus lieto, lai stabilizētu pārvietotos skrimšlus, sasniedzot nāsu, spārnu un degungala simetriju. Valnīšus izṇem pēc vienas nedēlas. Ja deformāciju iespējams koriḡèt, tad ne šķeltnes pusē neveic preparēšanu. Ja deformācija ir plašāka vai nevar sasniegt simetriju, tad veic griezienu gar nāss malu ne šķeltnes pusē, atpreparējot apakšējo laterālo skrimsli no ādas un dažreiz arī no zemāk esošiem audiem. Kad abas puses atpreparētas, veic balsta šuves un izveido deguna simetriju (Salyer, 1992).

\subsubsection{Skrimšḷa un kaula transplantācija}

Skrimšla augmentācija bieži uzlabo estētiskos rezultātus (Salyer, 1992). Byrd ar kolēgiem (2007) pie sekundāras deguna deformācijas, apsver indikācijas ribas skrimšla transplantātam, kā arī starpsienas un auss skrimšla lietderīgumu. Pie primāras, gan sekundāras deguna korekcijas, ir svarīgi līdzsvarot muskuļu spēku uz starpsienu un deguna spārna skrimsli. Deguna deformācijas pakāpi ietekmē gan skrimšlı nepareiza pozīcija, gan apakšējo laterālo skrimšļu hipoplāzija (Byrd et al., 2007). Bieži tiek lietots arī onlay skrimšla transplantāts, ko ņem no autogēna auss skrimšla un liek degungalā, lai uzlabotu tā projekciju (Matsuya et al., 2003). 
Salyer (1992) apraksta kaula transplantātus no galvaskausa kauliem. Kaulu iegūst neiroķirurgi ar kraniotomijas palīdzību. Kraniālā kaula gabals pēc izņemšanas tiek pārdalīts, atstājot ārējo virsmu ielikšanai atpakaļ donora vietā, bet iekšējo daļu izmanto kā implantu. Gadījumos, kad samazināts deguna spārna pamats šķeltnes pusēe, onlay transplantātu liek uz augšžokḷa kaula un fiksē ar titāna skrūvēm. To ievieto caur transbukālo griezienu nazolabiālā rievā un liek zem periosta. Pacientiem ar šķeltnēm to var likt arī citos rajonos, lai sasniegtu optimālu estētisko rezultātu (Salyer, 1992). Savukārt Ahuja (2001) dod priekšroku deguna muguras kaula augmentācijai no iegurņa kaula, jo no tā var iegūt daudz materiāla vienlaicīgi arī augšžokḷa augmentācijai. Īpaši nozīmīga kaula rezorbcija deguna muguras transplantātos netika novērota (Ahuja, 2001).

\subsection{Deguna elpošanas funkcija}

Lūpas un aukslēju škseltnes bieži asociējas ar deguna deformāciju kā starpsienas deviācija, nāsu atrēzija, konhu hipertrofija (īsta vai relatīva) un augšžokḷa augšanas aizture. Šīs deformācijas saistītas ne tikai ar iedzimtu defektu, bet arī ar deformācijām, kas radušās pēc ķirưǵiskajām operācijām. Deguna deformācijām ir tieksme samazināt deguna dobuma dimensiju, palielināt deguna rezistenci gaisa plūsmai un samazināt deguna funkciju. Tas viss noved pie kompensatoras mutes elpošanas un var kavēt kraniofaciālo augšanu un attīstību, zemāko elpceḷu funkciju un runas attīstību (Fukushiro \& Trindade, 2005). Literatūras dati (Jākobsone, 2003) liecina, ka bērniem aktīvās kraniofaciālās augšanas periodā deguna elpošanas patoloǵija varētu radīt oklūzijas un kraniofaciālās morfoloǵijas izmaiņas. Deguna starpsienas skrimšļainā daļa varētu būt iesaistīta sejas attīstībā arī kā augšanas centrs, kaut gan deguna starpsienas nozīme postnatālajā kraniofaciālajā attīstībā joprojām tiek diskutēta. Daži autori (Jākobsone, 2003) uzskata, ka deguna starpsiena ir augšanas centrs, kurš nosaka augšžokḷa augšanu uz priekšu un leju. Citi pētījumi norāda, ka deguna starpsiena darbojas tikai kā noturoša struktūra un postnatālajā periodā žokḷu augšana norisinās, pateicoties kaulu remodelācijai un relatīvajam sejas kaulu driftam attiecībā pret galvaskausu. Samazināta deguna elpošanas funkcija var ierosināt neiromuskulārās adaptācijas mehānismu, kuru Solow un Kreigborg 1977. gadā (Jākobsone, 2003) formulēja kā mīksto audu iestiepuma teoriju. Sejas mīksto audu iestiepuma rezultātā tiek kavēta augšžokļa transversālā augšana. Tiek traucēts intraorālo spēku balanss, jo bērnam elpojot caur muti, mēle neatrodas uz aukslējām. Jākobsone (2003) savā pētījumā secināja, ka deguna elpošanas funkcijai ir svarīga loma sakodiena un sejas skeleta attīstībā, bet deguna starpsienas deviācijas ietekmei nav specifiskas ietekmes augšžokḷa augšanā, tā ir atkarīga no deguna funkcijas traucējumiem (Jākobsone, 2003). 
Bērnam augot nereti saglabājas deguna elpošanas funkcijas traucējumi, kurus nepieciešams savlaicīgi novērtēt un novērst. Rinomanometrija ir biežāk lietotā tehnika, kuru lieto, lai noteiktu deguna kvantitatīvo funkciju, atḷaujot mērīt deguna rezistenci un minimālo deguna šksērsgriezuma laukumu (Fukushiro \& Trindade, 2005). Sandham un Murray (1993) veica rinomanometriju un tiešu starpsienas vizuālu priekšēju rinoskopiju. Šie autori secināja, ka starpsienas deviācija uz ne šķeltnes pusi kavē degungala skrimšlainās daļas augšanu (Sandham \& Murray, 1993).

\subsection{Deguna estētikas novērtēšanas metodes}

Samērīgs, simetrisks un proporcionāls - šādi estētiskie komponenti bija dokumentēti Senajā Ėǵiptē jau pirms 5000 gadiem. Šie estētiskie aspekti ir izdzīvojuši caur grieķu un romiešu kultūrām līdz šodienai kā skaistuma un sejas estētikas standarti (Russell et al., 2001). Diskusijas par deguna estētikas novērtēšanas metodēm pacientiem ar lūpu un aukslēju šķeltnēm joprojām ir aktuālas. Literatūrā atrodamas daudz un dažādas novērtēšanas metodes, kas norāda, ka neviena nav ideāla. Lai novērtētu sejas estētikas parametrus tika lietoti mākslinieku zīmējumi, attēli, fotogrāfijas, videoieraksti, ar datoru izveidotas bildes un dzīvi subjekti (Russell et al., 2001). Vairākos pētījumos deguna estētiskajai novērtēšanai tika lietotas vairākas mērījumu sistēmas un metodes vienlaicīgi.

Lai noteiktu piemērotāko un objektīvāko deguna estētikas novērtēšanas metodi, tika veikta sistemātiska literatūras analīze oriǵināl rakstiem angḷu valodā PubMed un MedLine datubāzēs no 1996. gada janvāra līdz 2017. gada jūnijam, lietojot šādus atslēgas vārdus: cleft nose/nasal aesthetic assessment, evaluation and measurement methods. Izslēgšanas kritēriji bija gadījumu apraksti, ķirurǵiski apraksti, literatūras analīzes apraksti, izolēti deguna funkcijas novērtēšanas pētījumi, izolēti pacientu pašnovērtējuma pētījumi. Kopumā tika atlasīti 143 oriğināl raksti, kuri tika analizēti pēc izmantotajām deguna estētikas novērtēšanas metodēm un mērāmajiem parametriem, nosakot metožu pozitīvo un negatīvo īpašību apkopojumu (skat. 1. pielikums). No atlasītajiem 143 rakstiem, 30 rakstos tika aprakstītas dažādas metožu kombinācijas. Trīs rakstos tika salīdzinātas divdimensiju un trīsdimensiju metodes ar neviennozīmīgiem rezultātiem (Al-Omari et al., 2003; Reiser et al., 2011; Stebel et al., 2016). Četros rakstos tika salīdzināta klīniskā izmeklēšana ar divdimensiju fotoattēliem (Becker et al., 1998; Hurwitz et al., 1999; Kim et al., 2004; Nagy \& Mommaerts, 2007).

Pitak - Arnnop ar kolēǵiem (2011) savā darbā apvienoja deguna estētikas novērtēšanu divdimensiju fotoattēlos, kurus novērtēja profesionāļi un ar medicīnu nesaistīti cilvēki un pašu pacientu apmierinātību ar savu deguna izskatu, izmantojot aptaujas. Tindlund ar 
kolẹgiem (2009) izmantoja divdimensiju fotoattēlus, rentgenogrammas, laterālās cefalogrammas, gipša veiduḷus, runas ierakstus un dzirdes novērtēšanu. Novērtēšanā tika veikta aprakstoša kraniofaciāla cefalometrijas analīze, dentoalveolārā morfoloǵija, dentofaciālā estētika, runas nazalitātes un artikulācijas ieraksti, dzirdes stāvoklis (Tindlund et al., 2009). Russell ar kolēgiem (2009) savukārt izmantoja vairāku metožu kombināciju kā divu un trīsdimensiju fotoattēlus, laterālās cefalogrammas, ǵipša deguna veiduḷus. Deguna ǵipša veiduļi tika novērtēti ar vizuālo analogu skalu. Autori secināja, kaut arī tika novērotas nelielas morfoloǵiskas atšķirības, tās nepierādīja estētiskā novērtējuma subjektivitāti (Russell et al., 2009). Kopumā autori secinājuši, ka visas metodes papildina viena otru (Kaiser et al., 1996; Anastassov et al., 1998; Russell et al., 2001; Brattström et al., 2005; Bongaarts et al., 2008; Reddy et al., 2008; Huempfner-Hierl et al., 2009; Russell et al., 2009; Tindlund et al., 2009; Nakamura et al., 2010; Chaithanyaa et al., 2011; Reiser et al., 2011; Roosenboom et al., 2014; Byrne et al., 2014; Alonso et al., 2014; Verzé et al., 2014; He et al., 2015; Dissaux et al., 2015).

Protams, arī elpošanas funkcija ir svarīga, ne tikai deguna estētiskais novērtējums. Deguna funkcija kopā ar estētiku tika novērtēta tikai piecos rakstos no 143 (Anastassov et al., 1998; Huempfner-Hierl et al., 2009; Reiser et al., 2011; Chaithanyaa et al., 2011; Keijser et al., 2016).

Literatūras analīzē, ko veica Al-Omari ar kolēǵiem (2005) tika secināts, ka nav atrasta neviena nevainojama metode ar kuru varētu novērtēt deguna estētiku. Tomēr kā viena no daudzsološākajām metodēm deguna estētikas novērtēšanai tika atzīti trīsdimensiju fotoattēli (Al-Omari et al., 2005). Tiek uzskatīts, ka tālāka deguna estētikas analīze trīsdimensiju fotoattēlos ar vairāk pacientiem palīdzētu novērtēt pēc operāciju rezultātus, lai varētu attīstīt labākas ķirurgiskās tehnikas, kas uzlabotu sejas simetriju (Stauber et al., 2008).

\subsubsection{Klīniska}

Literatūras analīzē no atlasītajiem 143 rakstiem, klīniskā izmeklēšana tika aprakstīta 16 rakstos, no kuriem astoņos rakstos aprakstīta kopā ar citām metodēm, kā divdimensiju fotoattēli (Becker et al., 1998; Hurwitz et al., 1999; Al-Omari et al., 2003; Kim et al., 2004; Nagy \& Mommaerts, 2007; Reddy et al., 2008; He et al., 2009b; Chaithanyaa et al., 2011), un trīsdimensiju fotoattēli (Al-Omari et al., 2003). Nagy un Mommaerts (2007) uzskata, ka tieši antropometriski mērījumi ir visprecīzākie un labi akceptēti antropologu vidū, bet ir problemātiski veikt atkārtotus mērījumus īpaši, ja ir liels pacientu skaits (Nagy \& Mommaerts, 2007). Kā arī pacientu novērošana dinamikā ir sarežǵīta un izsaukšana uz kontroli var būt maz 
efektīva un, protams, bērni aug starp apmeklējuma vizītēm. Turklāt ir praktiski neiespējami salīdzināt rezultātus starp dažādiem centriem (Nagy \& Mommaerts, 2007). Al-Omari ar kolẹgiem (2003) savā pētījumā salīdzināja sejas deformācijas klīnisko novērtēšanu ar novērtēšanu divu un trīsdimensiju fotoattēlos. Abas sejas deformācijas novērtēšanas metodes fotoattēlos uzrādīja precīzāku un vieglāk atkārtojamu rezultātu nekā klīniskā novērtēšana (Al-Omari et al., 2003). Becker ar kolēǵiem (1998) secinājuši, ka klīniskā novērtēšana varētu būt ierobežota dēḷ funkcionāliem aspektiem un subjektīva viedoķ̣a veidošanos par degunu, lūpām un visu seju. Ja ir šis subjektīvais novērtējums, tad, ja nepieciešams, var atkārtot mērījumus izmantojot digitālās fotogrāfijas, jo visa informācija tiek glabāta pastāvīgi. Šie autori secinājuši, ka metodes varētu viena otru papildināt (Becker et al., 1998).

\subsubsection{Divdimensiju fotoattēli}

Joprojām vispopulārākā metode deguna estētikas novērtēšanai ir divdimensiju fotoattēli, šī metode tika aprakstīta 90 rakstos no 143 atlasītajiem. Divdimensiju fotoattēli plaši tika aprakstīti arī pēdējo gadu rakstos. No 90 rakstiem, kuros deguna estētikas noteikšanai bija izmantoti divdimensiju fotoattēli, 24 rakstos tika aprakstītas kombinācijas ar citām metodēm. Kombinācijas bija dažādas - rinomanometrija (Anastassov et al., 1998; Huempfner-Hierl et al., 2009; Keijser et al., 2016), datortomogrāfija (Li et al., 2012; Scopelliti et al., 2013; Alonso et al., 2014) laterālās cefalogrammas (Anastassov et al., 1998; Brattström et al., 2005; Russell et al., 2009; Tindlund et al., 2009; Scopelliti et al., 2013) sejas gipša veiduḷi (Kaiser et al., 1996; Russell et al., 2001; Bongaarts et al., 2008; Russell et al., 2009; Tindlund et al., 2009), trīsdimensiju fotoattēli (Al-Omari et al., 2003; Nakamura et al., 2010; Stebel et al., 2016), klīniskā izmeklēšana (Becker et al., 1998; Hurwitz et al., 1999; Al-Omari et al., 2003; Kim et al., 2004; Nagy \& Mommaerts, 2007; Reddy et al., 2008; He et al., 2009b; Chaithanyaa et al., 2011), video ieraksti (Dissaux et al., 2015) un aptaujas (Pitak-Arnnop et al., 2011; Gassling et al., 2015).

Divdimensiju fotoattēli sniedz iespēju pacientus novērtēt konsekventi pēc operācijām ar dažādām metodēm. Otra priekšrocība, ka digitālās fotogrāfijas tiek glabātas pastāvīgi, tāpēc jaunas idejas var testēt uz tām pašām fotogrāfijām. Tagad, kad datu pārraides ir pieejamas visā pasaulē, tā ir spēja nodrošināt multicentru pētījumus, kad nepieciešami vienoti vērtējumi par dažādiem klīniskiem gadījumiem, dažādās vietās un neatkarīgiem novērtētājiem (Becker et al., 1998). 


\subsubsection{Trīsdimensiju fotoattēli}

Deguna estētikas novērtēšana trīsdimensiju fotoattēlos tika aprakstīta 31 rakstā no 143 atlasītajiem rakstiem. Al-Omari ar kolēǵiem (2005) literatūras analīzē trīsdimensiju fotoattēli tika novērtēti visaugstāk un šāds uzskats joprojām pastāv. Pārsvarā tika lietota trīsdimensiju stereo-fotogrammetrija (Hood et al., 2003; Hood et al., 2004; Singh et al., 2005; Devlin et al., 2007; Weinberg et al., 2009; van Loon et al., 2010; Zreaqat et al., 2012; Othman et al., 2014; Bell et al., 2014; Tse et al., 2014; Bugaighis et al., 2014a; Bugaighis et al., 2014b; Desmedt et al., 2015; Stebel et al., 2016) un trīsdimensiju optiskā skenēšana (Yamada et al., 1999; Duffy et al., 2000; Yamada et al., 2002; Bilwatsch et al., 2006; Verzé et al., 2014; Dadáková et al., 2016). Dažos rakstos tika aprakstîts elektromagnētisks trīsdimensiju sejas mīksto audu punktu atlicējs (Ferrario et al., 2003), bez kontakta tipa semikonduktora lāzera trīsdimensiju mērīšanas sistēma (Mori et al., 2005; Okawachi et al., 2011), trīsdimensiju vision-based fotografěšana (Ayoub et al., 2011) un trīsdimensiju videobased ierakstīšanas sistēma (Trotman et al., 2007). Trīsdimensiju simetrijas analīze tika aprakstīta arī deguna gipša veiduļiem, kuri ieskanēti ar elektromagnētisko skeneri (Russell et al., 2011).

Galvenie secinājumi bija, ka trīsdimensiju metodes bija labākās, lai novērtētu lūpu un degunu pēc šķelț̣u operācijām (Mori et al., 2005). Devlin ar kolēǵiem (2007) secinājuši, ka trīsdimensiju stereo-fotogrammetrija bija neinvazīva, precīza un pieejama metode, lai novērtētu sejas formu un ķirurǵiskās pārmaiņas. Ar šo metodi deguna simetriju varēja kvantitatīvi un ticami novērtēt (Devlin et al., 2007). Daudzi autori bija norādījuši, ka turpmāka trīsdimensiju analīze ar vairāk pacientiem ļaus pilnveidot ķirurğijas metodes, lai uzlabotu sejas simetriju, kas jāpierāda ar plašāku un sistemātiskāku analīzi (Stauber et al., 2008).

\subsubsection{Cefalogrammas un datortomogrāfija}

Deguna estētikas novērtēšana cefalogrammās un datortomogrāfijā tika aprakstīta 20 rakstos no 143 atlasītajiem. Cefalogrammu lietošana tika aprakstīta 12 rakstos (Smahel \& Müllerova, 1996; Anastassov et al., 1998; Bearn et al., 2002; Yoon et al., 2003; Brattström et al., 2005; Russell et al., 2009; Tindlund et al., 2009; Chaithanyaa et al., 2011; Ridgway et al., 2011; Papamanou et al., 2012; Scopelliti et al., 2013; Verzé et al., 2014), bet datortomogrāfija astoņos rakstos (Fisher et al., 1999; Suri et al., 2008; Nagasao et al., 2008; Miyamoto \& Nakajima, 2010; Li et al., 2012; Miyamoto et al., 2012; Scopelliti et al., 2013; Alonso et al., 2014). Vairumā gadījumos, šīs metodes lietotas kombinācijās ar citām deguna 
estētikas novērtēšanas metodēm. Piemēram, cefalogrammas visbiežāk tika kombinētas ar divdimensiju fotoattēliem (Anastassov et al., 1998; Brattström et al., 2005; Russell et al., 2009; Tindlund et al., 2009; Scopelliti et al., 2013). Ridgway ar kolēgiem (2011) savā pētījumā novērtēja deguna starpsienas deviāciju pacientiem ar škseltnēm, lietojot posterior-anterior cefalogrammas (Ridgway et al., 2011). Autori secinājuši, ka šī bija vienkārša metode un pacienti saņēma mazāku radiācijas devu salīdzinot ar datortomogrāfiju, lai arī posterioranterior cefalogrammas sniedza tikai divdimensiju attēlu no trīsdimensionālas starpsienas deviācijas. Tomēr šie autori uzskata, ka tas attaisnoja izmaksas, ieguvumus un riskus îpaši bērniem, kuriem jānosaka tikai starpsienas pozīcija, attiecībā ar datortomogrāfiju (Ridgway et al., 2011). Jāatzīst, ka cefalogrammu lietderīgums sejas mīksto audu mērījumiem nav pierādīts (Bearn et al., 2002a).

Savukārt Suri ar kolēgiem (2008) uzskata, ka datortomogrāfija bija ļoti laba metode, lai kvantitatīvi analizētu virsējās un dziḷās kraniofaciālās struktūras. $L i$ ar kolēǵiem (2012) savā darbā salīdzināja mērījumus no fotogrāfijām ar konusa staru datortomogrāfiju un secināja, ka kombinācijā šīs metodes bija uzticamas, lai novērtētu cieto un mīksto audu attiecības lūpas un deguna rajonā. Šie autori ievēroja, ka mīkstie audi var noslēpt cieto audu deformācijas un ir ļoti svarīgi to ņemt vērā pie sekundāras deguna korekcijas (Li et al., 2012). Fisher ar kolēgeiem (1999) novēroja, ka trīsdimensionālas datortomogrāfijas datu analīzei bija vairākas priekšrocības salīdzinājumā ar citām tehnikām, kuras lieto deguna deformācijas novērtēšanai pacientiem ar lūpas šķeltni. Mērījumi tika veikti bērniem sedācijā, lai izslēgtu muskuḷu kustības vai citus ārējus deformējošu faktorus. Attēli tika novērtēti vairākās pozīcijās un atlikti un mērīti gan mīksto audu, gan cieto audu anatomiskie punkti. Tika secināts, ka iegūtie mērījumi ar šo metodi var tikt atkārtoti un pārbaudīti, bet mīksto audu mērījumu precizitāte datortomogrāfijā joprojām vēl jāpierāda (Fisher et al., 1999).

Datortomogrāfija ir vien̄̄gā izmeklēšanas metode, lai objektīvi novērtētu deguna starpsienas novirzi. Savukārt cefalogrammas ir jau sen izveidota metode, kas ir plaši pieejama un pārsvarā tiek izmantota ortodontijā.

\subsubsection{Sejas ğipša veiduli}

Sejas ǵipša veiduļu lietošana tika aprakstīta 11 rakstos no 143 atlasītajiem. Visbiežāk ǵipša veiduļi tika izmantoti kombinācijā ar divdimensiju fotoattēliem (Kaiser et al., 1996; Russell et al., 2001; Bongaarts et al., 2008; Russell et al., 2009; Tindlund et al., 2009). Dusková ar kolēgiem (2006) savā pētījumā ņēma ǵipša nospiedumus no sejas un veica deguna morfologijas mērījumus ar tiešu antropometriju uz ğipša veiduļiem. Autori secināja, ka š̄ 
metode bija objektīva, mērījumi bija precīzāki, jo mīkstie audi netika deformēti, ja nepieciešams, mērījumi var tikt atkārtoti un papildināti, tie atainoja trīsdimensionālu veidolu, kā arī metode bija viegli pieejama un ar zemu pašizmaksu (Dusková et al., 2006). Trīs rakstos deguna estētikas mērījumi tika veikti ieskenētos deguna veiduļos (Russell et al., 2001; Mishima et al., 2002; Russell et al., 2011), savukārt citos rakstos mērījumi tika veikti tieši uz ǵipša veiduḷiem (Dusková et al., 2006; Russell et al., 2009; Barillas et al., 2009).

\subsubsection{Video ieraksti}

Sejas video ierakstīšana tika aprakstīta četros rakstos no 143 atlasītajiem. Trotman ar kolēgiem (2007) lietoja video-based ieraksta sistēmu, lai novērtētu mutes apvidus kustības katram pētījuma dalībniekam (Trotman et al., 2007). Šī sistēma ierakstīja retro-reflektīvus marķierus, lai noteiktu specifiskus sejas anatomiskos punktus. Pētījumā tika salīdzinātas mutes apvidus kustības starp trīs grupām: grupu ar slēgtu lūpas šķeltni, kuriem būtu nepieciešama atkārtota lūpas muskuļu korekcija, bet tā vēl nav veikta, grupu ar izoperētu lūpas škseltni un grupu ar pacientiem, kuriem nav škseltnes. Autori secināja, lai ticami salīdzinātu grupas, bija nepieciešami vairāki mutes apvidus kustību ieraksti (Trotman et al., 2007). Morrant un Shaw (1996) veica video ierakstus 30 šķelțu pacientiem. Ieraksti tika veikti no sešiem dažādiem rakursiem, kuru laikā pacientiem tika lūgts atkārtot trīs frāzes un veikt vairākas secīgas lūpu kustības. Novērtētāju ticamība bija robežās no sliktas līdz ļoti labai atkarībā no lūpu un deguna atšķirīgām pazīmēm. Autori secināja, ka šī metode var tikt lietota kvalitātes nodrošināšanā, salīdzināšanai starp centriem, vai ķirurğisko tehniku efektivitātes novērtēšanai. Tomēr pacientiem ir jābūt pietiekoši veciem, lai spētu sadarboties un novērtētājiem ir jābūt labi apmācītiem, lai mērījumi būtu ticami un atkārtojami (Morrant \& Shaw, 1996). Russell ar kolēgiem (2000) filmēja deguna veiduḷus un analizēja nāsu struktūru no leņ̧̧a ar vislielāko laukumu. Autori secināja, ka viņi ir izveidojuši un pierādījuši objektīvu un kvantitatīvu metodi, lai novērtētu nāsu un deguna morfolog̣iju pacientiem ar šķeltnēm (Russell et al., 2000). Dissaux ar kolēgiem (2015) veica deguna un lūpas estētikas novērtējumu divdimensiju fotoattēlos un video ierakstos 10 bērniem ar vienpusēju caurejošu lūpas, alveolārā izauguma un aukslēju šķeltni un 10 bērniem ar divpusēju lūpas un aukslēju šķeltni katrā no četriem Francijas šķeltņu centriem. Autori secinājuši, ka deguna un lūpas estētikas novērtēšanas metodes papildina viena otru, tās bija vienkāršas, atkārtojamas, uzticamas un l̦āva novērtēt šķeltņu primārās ķirurǵijas rezultātus (Dissaux et al., 2015). 


\subsection{Deguna estētikas novērtēšanas mērāmie parametri}

Šobrīd nav pieņemamas metodes, ko lietot, lai noteiktu estētiku objektīvā un kvantitatīvā veidā, kā arī, lai novērtētu dažādu ārstēšanas metožu efektivitāti (Russell et al., 2001). Literatūrā atrodamas daudz un dažādas mērījumu metodes un mērāmie parametri, lai aprakstītu sejas un deguna morfolog̣iju, sākot no Farkas detalizētiem antropometriskiem mērījumiem līdz datorizētām antropometriskām mērījumu metodēm, graduēto skalu mērījumiem un vienkāršam aptaujām.

\subsubsection{Antropometriskie mērījumi}

Antropometriskai novērtēšanai dz̄iviem cilvēkiem lieto modernus datorizētus instrumentus, tā papildinot vai pat aizstājot konvencionālos tiešos antropometriskos mērījumus. Šie instrumenti var tikt iedalīti divās galvenajās grupās - optiskie, bezkontakta instrumenti (lāzerskaneri, trīsdimensiju plaša spektra kameras, stereo-fotogrammetrija), kas atveido sejas virsmu un tieša kontakta instrumenti, kas ieskanē tikai izvēlētos antropometriskos punktus. Abas metožu grupas matemātiski rekonstruē ādas virsmas anatomiskās pazīmes un var tikt veikti šādi ǵeometrisku mērījumu etapi: lineāri attālumi un leņķi, līdzīgi kā pie konvencionālas antropometrijas, kā arī tilpumi un virsmas laukumi (Ferrario et al., 2007). Devlin ar kolēgiem (2007) uzskata, ka ar 3D stereo-fotogrammetriju deguna simetrija var tikt kvantitatīvi un precīzi izmērīta (Devlin et al., 2007).

Ferrario ar kolēgiem (2007) savā darbā atzīmēja viduslīnijas (nepāra) anatomiskos punktus, pāru anatomiskos punktus, attālumus mērīja milimetros un leņķus grādos. Viņi aprēķināja arī deguna ārējās virsmas laukumu $\left(\mathrm{mm}^{2}\right.$ ) (trīsstūru laukumu summa $n-p r n-a c$ abās pusēs, prn-sn-ac abās pusēs) un tilpumu $\left(\mathrm{mm}^{3}\right)-2$ prizmu tilpuma summa $-a c-a c$, prn-ac pamats un virsotne $-n$, otrs - tas pats pamats un virsotne $s n$ (skat. 1.11. att. un 1.1. tab.) (Ferrario et al., 2007). 


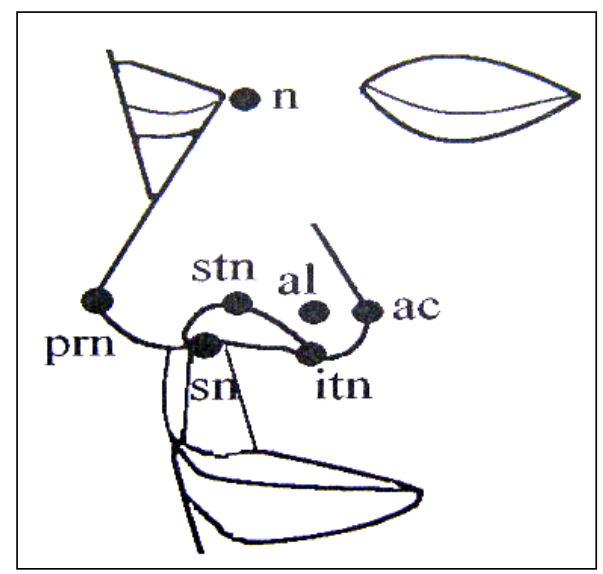

1.11. att. Mīksto audu anatomisko punktu shematisks attēls (Ferrario et al., 2007)

1.1. tabula

Sejas anatomiskie punkti (Ferrario et al., 2007)

\begin{tabular}{|l|l|}
\hline \multicolumn{1}{|c|}{ Saīsinājums } & \multicolumn{1}{c|}{ Anatomiskie punkti } \\
\hline $\mathrm{n}$ & nasion \\
\hline prn & pronasion \\
\hline Sn & subnasale \\
\hline al & deguna spārns \\
\hline ac & deguna spārna mala \\
\hline itn & apakšējais nāsu punkts \\
\hline stn & augšejais nāsu punkts \\
\hline al-al & deguna platums \\
\hline prn-sn, prn-al-al & degungala protrūzija \\
\hline n-sn & deguna augstums \\
\hline n-prn & deguna garums \\
\hline stn-itn & labais un kreisais nāsu garums \\
\hline stn-stn & augšējais nāsu platums \\
\hline itn-itn & apakšējais nāsu platums \\
\hline ac-ac & spārnu pamatnes platums \\
\hline al-prn-al & spārnu slīpums \\
\hline n-prn-sn & degungals \\
\hline sn-n-prn & deguna prominence jeb izliekums \\
\hline
\end{tabular}

Yamada ar kolēgiem (2002) izvēlējās citus anatomiskos punktus (skat. 1.12. att. un 1.2. tab.). Šie autori atrada šādas galvenās novirzes - plata interkantālā distance, deguna spārna saplacinājums šķeltnes pusē, kolumellas pamatnes deviācija uz ne šķeltnes pusi un kolumellas inklinācija, saplacināts degungals, spārnu un nāsu asimetrija, lūpu lociṇu asimetrija (Yamada et al., 2002). 


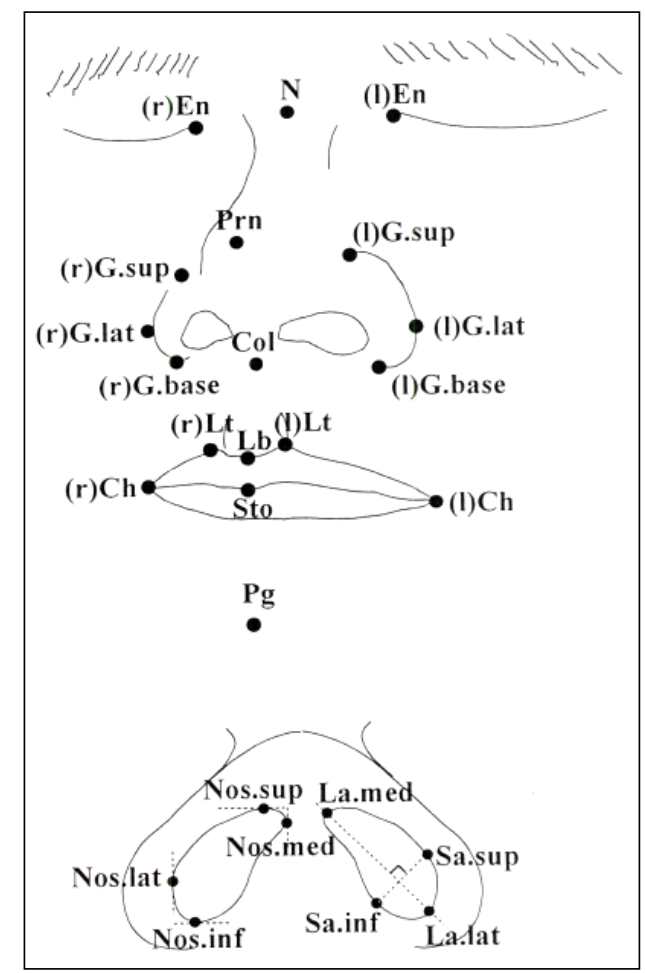

1.12. att. Sejas anatomisko punktu shematisks attēls (Yamada et al., 2002)

1.2. tabula

Sejas anatomiskie punkti (Yamada et al., 2002)

\begin{tabular}{|l|l|}
\hline \multicolumn{1}{|c|}{ Saīsinājums } & \multicolumn{1}{c|}{ Anatomiskie punkti } \\
\hline En & Endokants \\
\hline $\mathrm{N}$ & Nasion (mīkstajos audos) \\
\hline Pg & Pogonion (mīkstajos audos) \\
\hline Prn & Degungals \\
\hline G-sup & Alar rievas augšējais punkts \\
\hline G- lat & Alar rievas laterālais punkts \\
\hline G-base & Alar rievas apakšējais punkts \\
\hline Col & Kolumellas pamatne \\
\hline Lt & Cupid loka virsotne \\
\hline Lb & Cupid loka pamatne \\
\hline Sto & Stomion \\
\hline Ch & Cheilion \\
\hline Nos-sup & Nāsu augstākais punkts \\
\hline Nos-inf & Nāsu zemākais punkts \\
\hline Nos-med & Nāsu mediālais punkts \\
\hline Nos-lat & Nāsu laterālais punkts \\
\hline La-med & Nāsu garenass mediālais punkts \\
\hline La-lat & Nāsu garenass laterālais punkts \\
\hline Sa-sup & Nāsu šǩērsass augšējais punkts \\
\hline Sa-inf & Nāsu šķērsass apakšējais punkts \\
\hline
\end{tabular}


Brattström ar kolēgiem (2005) savā pētījumā izmantoja laterālās cefalogrammas attēlus, vēlāk tās digitāli tika apstrādātas. Šajā pêtījumā izmantoja ortodontijā lietotos cefalometrijas anatomiskos punktus (Brattström et al., 2005).

Savukārt Liou ar kolēgiem (2004) piecus lineārus mērījumus veica 2D fotogrāfijās. Horizontālās atskaites līnija tika konstruēta, savienojot viszemākos punktus ārējās laterālās nāsu malās šķeltnes un ne šķeltnes pusē. Antropometriskie punkti tika konstruēti piecos lineāros mērījumos. Visi mērījumi tika veikti no atskaites līnijas (skat. 1.13. att.).

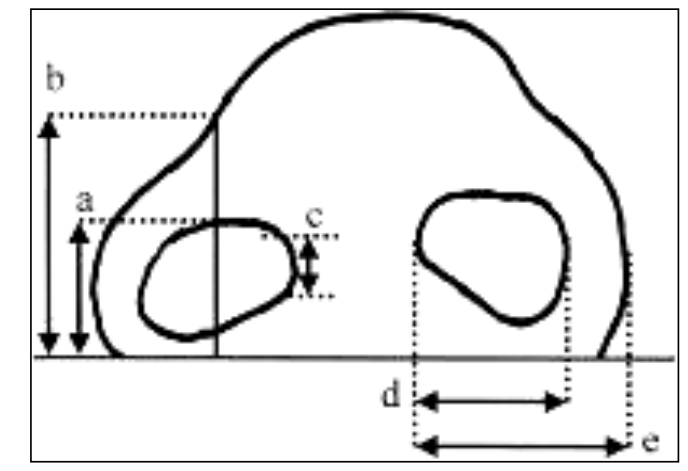

1.13. att. Shematisks antropometrisko mērījumu attēls (Liou et al., 2004)

Šie autori veica šādus vertikālos mērījumus: a - nāsu augstums: vertikāls attālums starp horizontālo līniju un starppunktu no iekšējās augšējās nāss robežas, un perpendikulāro bisektrises līniju no nāsu platuma; b - deguna kupola augstums: vertikāls attālums starp horizontālo līniju un starppunktu no ārējās augšējās nāss robežas, un perpendikulāro bisektrises līniju no nāss platuma; c - kolumellas garums: vertikāls attālums starp viszemāko mediālo un augstāko mediālo punktu nāsu atveru iekšējā mediālā virsmā. Kā arī sekojošus horizontālos mērījumus: $d$ - nāsu pamatnes platums: horizontālais attālums starp ārējo laterālo robežu un iekšējo mediālo nāsu robežu; e - nāsu platums: horizontālā platākā vieta starp iekšējo laterālo un mediālo nāsu atveres robežu (skat. 1.13. att.). Deguna simetrija tika novērtēta pēc "asimetrijas kvantitātes". Asimetrijas kvantitāte (milimetros) bija lineāra katra mērījuma starpība starp šķeltnes un ne šķeltnes pusi. Pozitīvi lielumi norādīja, ka šķeltnes puse bija garāka / platāka nekā ne šķeltnes puse un negatīvi lielumi norādīja, ka šķeltnes puse bija īsāka / šaurāka. Deguna augšana / relapss bija lineāra starpība milimetros katram vertikālam / horizontāla mērījumam (Liou et al., 2004).

Kim ar kolēgiem (2004) savā pētîjumā novērtēja nāsu simetriju, deguna kupola velves projekciju, deguna spārnu skrimšlı deformācijas korekcijas pakāpi un deguna spārnu pamatnes saplacinājumu. Kā arī degungala projekcijas garumu (sn-prn), kolumella (sn-c) un deguna platumu (al-al) (skat. 1.14. att.). Mērījumi tika veikti 6 mēnešus un 3 gadus pēc primāras 
deguna plastikas un salīdzināti ar veseliem bērniem. Lai izvairītos no kḷūdām antropometriskos mērījumus veica tikai viena persona (Kim et al., 2004).

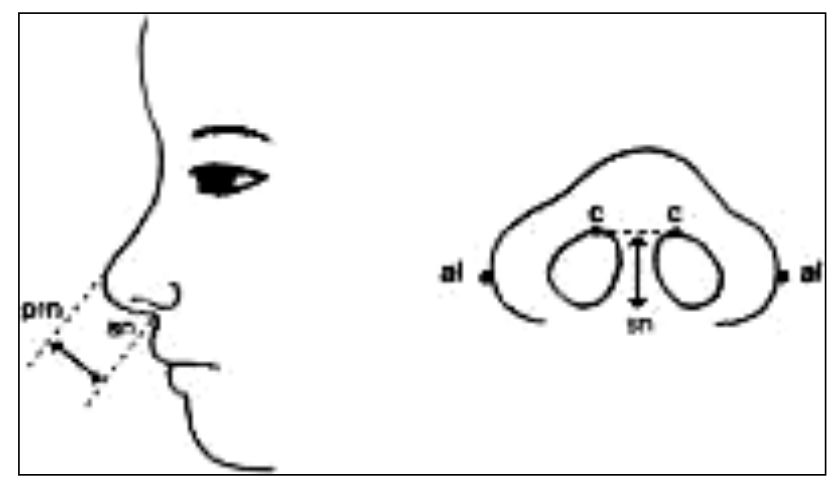

1.14. att. Shematisks antropometrisko mērījumu anatomisko punktu attēls (Kim et al., 2004) Prn - pronasale; sn - subnasale; c-kolumella; al - alae

Nagasao ar kolēǵiem (2008) savā darbā mērīja deguna profila deformācijas, īpašu uzmanību pievēršot degungalam. Šie autori uzsver, ka anatomiskais punkts pronasale, sākotnēji definēts kā visvairāk uz priekšu uzvirzīts degungala punkts, bet vēlāk kā deguna visvairāk anteriori novietots punkts, nav viens un tas pats. Tie īpaši atšķiras pie deguna deformācijas šķeltņu gadījumos (Nagasao et al., 2008).

Tā kā pastāv nevienprātība anatomisko punktu atlikšanā un to definēšanā, rakstos parādās jaunas automatizētas punktu atlikšanas programmas, šobrīd gan tās ir tikai eksperimentālā stadijā. Piemēram, Mishima ar kolēǵiem (2002) savā pētîjumā lietojuši precīzu, kvantitatīvu metodi, lai mērītu ārējo deguna formu izmantojot pusautomātisku anatomisko punktu atlikšanas programmu uz g̊ipša sejas veiduļiem. Pagaidām šī programma izmēgeināta tikai pieciem pacientiem, tomēr autori uzskata, ka šî ierīce bija ar augstu precizitāti kontakt-tipa trīsdimensionāla koordināšu mērīšana (Mishima et al., 2002). Pigott R. W. un Pigott B. B. 2010. gadā publicējuši SymNose programmu. Šīs programmas mērķis bija izmērīt deguna un lūpas asimetriju divdimensiju fotoattēlos pacientiem ar lūpas un aukslēju šķeltni. Divdimensiju fotoattēlos frontālā un bazālā projekcijā manuāli tika apvilktas anatomiskās struktūras, kurām vēlas noteikt simetriju, pēc tam programma nosaka šķeltnes puses nesakritību ar veselo pusi. Pēc autoru domām SymNose bija ātra un vienkārši lietojama objektīva metode deguna un lūpas simetrijas novērtēšanai pacientiem ar lūpas un aukslēju škseltni (Pigott R.W. \& Pigott B.B., 2010). SymNose metodes precizitāti un ticamību ir pārbaudījuši vairāki autori ar ievērojamām variācijām intra un inter novērtētāju ticamībai (McKearney et al., 2013; Freeman et al., 2013; Russell et al., 2014; Mosmuller et al., 2016a). Mosmuller ar kolẹgiem (2016a) veikuši SymNose programmas lietošanas un ticamības pārbaudi deguna un lūpas mērījumiem pacientiem ar 
vienpusēju lūpas un aukslēju šķeltni. Mērījumus veikuši četri novērtētāji. Autori atklāj, ka bija nepieciešamas daudzas video-konferences un e-pastu sarakstes ar SymNose programmas izgudrotājiem, lai pilnībā saprastu programmu. Mosmuller ar kolēǵiem (2016a) izveidojuši vienkāršotu lietošanas instrukciju un video, lai citiem autoriem būtu vieglāka SymNose programmas lietošana. Mosmuller ar kolēgiem (2016a) secinājuši, ka SymNose bija praktiska un ticama metode retrospektīviem pētījumiem divdimensiju fotoattēlos pacientiem ar šķeltnēm, tomēr arī šiem autoriem bija ne tikai augsti, bet arī vidēji intra un inter novērtêtāju rādītāji (Mosmuller et al., 2016a). Šādas automatizētas metodes pagaidām nav populāras, jo tās ir samērā sarežǵḡtas ikdienas lietošanā, jāiegādājas speciāla programmatūra un nepieciešamas papildu iemaņas, bet nākotnē varētu būt daudzsološas.

\subsubsection{Graduēto skalu mērījumi}

Graduētās skalas bija otra populārākā mērīšanas sistēma, tā aprakstīta 44 rakstos no 143 atlasītajiem rakstiem. Arī šajā novērtēšanas sistēmā bija savi trūkumi, nav vienprātības ar kādu mērīšanas skalu būtu jāstrādā. Pastāv piecu punktu, četru punktu un trīs punktu graduētas skalas, kas atkal atšķiras savā starp pētījumiem. Dažos pētījumos tika lietotas graduēto skalu kombinācijas, piemēram, Byrne ar kolēǵiem (2014) izmantoja gan 3-punktu graduētu skalu, gan 5-punktu graduētu skalu, gan specializētu 5-punktu graduētu skalu, kuru izstrādāja Asher-McDade ar kolēgiem (1991) un arī pacientu aptauju. Pārsvarā pētījumos lietotās graduētās skalas uzrādīja labus ticamības rādītājus gan savstarpēji starp vairākiem novērtētājiem (inter novērtētāja variabilitāte), gan vienam novērtētājam nosakot mērījumus atkārtoti (intra novērtētāja variabilitāte). Biežāk pētījumos bija aprakstīta piecu punktu graduēta skala, kuru izstrādāja Asher-McDade ar kolēǵiem (1991), publikācijās norādīta arī kā 5-punktu estētikas indekss. Asher-McDade ar kolēgiem 1991. gadā publicēja jaunu deguna un lūpas izskata novērtēšanas metodi pacientiem ar lūpas un aukslēju šķeltni divdimensiju fotoattēlos. Divdimensiju fotoattēli tika sagatavoti tā, lai novērtēšanai būtu redzami tikai deguns un augšlūpa. Attēlos tika novērtēta deguna forma, deguna simetrija, augšlūpas sārtās daļas robežas kontūra, deguna profils kopā ar augšlūpu. Šo komponentu novērtēšanai tika izmantota piecu punktu graduēta skala, kur 1 ir ļoti labs izskats, 2 - labs izskats, 3 - vidējs izskats, 4 - slikts izskats, 5 - l̦oti slikts izskats. Novērtēšanu veica pieci novērtētāji ar labiem intra un inter novērtētāja ticamības rezultātiem (Asher-McDade et al., 1991). Vēlāk šo deguna un lūpas novērtēšanas metodi izmantoja Eurocleft pētījumā (Asher-McDade et al., 1992), Eurocleft follow-up pētījumā (Brattström et al., 2005), Americleft pētījumā (Mercado et al., 2011; Mercado et al., 2016), kā arī citi (Nollet et al., 2007; Kuijpers-Jagtman et al., 2009; 
Fudalej et al., 2009; Paiva et al., 2014; Gassling et al., 2015; Sitzman et al., 2015; Rubin et al., 2015). Visi autori šo estētikas indeksu bija lietojuši deguna un lūpas estētikas novērtēšanai divdimensiju fotoattēlos, izṇemot Morrant un Shaw (1996) pielāgoja šo indeksu estētikas novērtēšanai video ierakstos, bet Desmedt ar kolēǵiem (2015) trīsdimensiju fotoattēlos.

Piemēram, Sugihara ar kolēgiem (1993) izmantoja cita veida graduētu skalu pēc operācijas deguna formas novērtēšanai divdimensiju fotoattēlos frontālā un pamatnes skatupunktā. Tika izšksirtas piecas kategorijas: (1) deguna spārna un spārna rievas asimetrija, (2) apakšèjā starpsienas deviācija uz mugurpusi no frontāla skatupunkta, (3) degungala deformācija, (4) laterālā spārna loka un kolumellas deformācija, (5) nāsu asimetrija no pamatnes skatupunkta. Katra kategorija tika novērtēta ar rezultātu 0, 1, 2. Kopējo rezultātu 0 līdz 2 - uzskatīja par labu, 3 līdz 4 par vidēju, 5 un vairāk par sliktu (skat. 1.3. tab.) (Sugihara et al., 1993).

1.3. tabula

Pēc operācijas rezultātu novērtēšanas graduēta skala (Sugihara et al., 1993)

\begin{tabular}{|l|l|l|}
\hline \multicolumn{2}{|c|}{ Kategorija } & Rezultāts \\
\hline Frontāls skatupunkts & 1. deguna spārna un spārna rievas asimetrija & $0,1,2$ \\
& 2. Apakšēā starpsienas deviācija uz mugurpusi & $0,1,2$ \\
\hline Pamatnes skatupunkts & 3. Degungala deformācija & $0,1,2$ \\
& 4. Laterālā deguna spārna loka un kolumellas deformācija & $0,1,2$ \\
& 5. Nāsu asimetrija & $0,1,2$ \\
\hline \multirow{2}{*}{ Kopējie rezultāti } & Labi & $0-2$ \\
& Vidēji & $3-4$ \\
& Slikti & $\geq 5$ \\
\hline
\end{tabular}

Arī RSU docente Biruta Barkāne 1968. gadā savā disertācijas darbā izmantoja graduētu skalu, kurā deguna un lūpas estētikas rezultāti tika sagrupēti trīs grupās - "labi”, "apmierinoši” un "neapmierinoši”. Labi rezultāti tika uzskatīit, ja tika sasniegta pareiza lūpas un deguna forma ar normālu funkciju. Apmierinoši rezultāti tika uzskatīti, ja pēc sekundāras korekcijas tika sasniegts ievērojams uzlabojums, bet tomēr saglabājās nelielas lūpas un deguna deformācijas. Neapmierinoši rezultāti tika uzskatīti, ja pēc sekundāras lūpas un deguna korekcijas to uzlabojums bija neliels un joprojām bija palikusi ievērojama deformācija un nepieciešama atkārtota ķirurǵiska korekcija (Баркане, 1968).

Savukārt Anastassov un Chipkov (2003) uzskata, lai objektīvi novērtētu pēc operācijas deformācijas, būtu jānovērtē arī pirms operācijas deformācijas smagums. Tā varētu diferencēt deformācijas, kuras radušās no pašas patoloğijas, no jatrogēni izraisītas deformācijas un no nepietiekošas primāras korekcijas. Savā pētījumā autori izmantoja klīnisku novērtēšanas skalu, kurā shematiski attēlotas lūpas un deguna deformācijas, atkarībā no smaguma pakāpes tika 
piešķirti punkti no 0,5 līdz 3, kuru summa veido attiecīgo rezultātu: 0-1,5 - izcili, 2-3,5 - l̦oti labi, 4-5,5 - labi, 6-8 - apmierinoši, 8,5-16 - slikti. Līdzīgi tika novērtēta arī pirms operācijas šķeltņu smaguma pakāpe (Anastassov \& Chipkov, 2003).

\subsubsection{Vizuālo analogu skalas}

Lai arī vizuālo analogu skalas (VAS) neuzrādīja labus reproduktivitātes un ticamības rezultātus (Asher-McDade et al., 1991), tās joprojām tika lietotas pētījumos vienkāršās un saprotamās lietošanas dēḷ. VAS var lietot paši pacienti vai neprofesionāļi. VAS vērtējumā rezultātu ticamību ietekmē tikai cilvēciskais faktors, jo tās pamatā ir ,patīk”, „nepatīk” princips. Tāpēc pētījumos to izmanto samērā reti un bieži kopā ar vēl kādu objektīvāku novērtēšanas metodi. Piemēram, Chaithanyaa ar kolēgiem (2011) novērtēja deguna estētiku pēc sekundāras rinoplastikas pacientiem ar lūpas un aukslēju šķeltni pēc piecu punktu skalas, antropometriskiem mērījumiem un pašu pacientu apmierinātību ar rezultātu pēc VAS (Chaithanyaa et al., 2011). Savukārt Russell ar kolēgiem (2001) izmantoja VAS nāsu morfoloǵijas novērtēšanai no ǵipša veiduliem, deguna estētikas novērtēšanai no video ierakstiem, kā arī antropometriskus mērījumus deguna formas novērtēšanai (Russell et al., 2001). Vizuālo analogu skala ir laba metode, ja jānovērtē nespeciālista viedoklis, piemēram, pašu pacientu novērtējums, kā to savā pētījumā bija veicis Sinko ar kolēǵiem (2005). Šie autori VAS izmantoja deguna estētikas un funkcijas novērtēšanai, kuru veica paši pacienti un šķeltņu komanda (ķirurgs, ortodonts, logopēds, psihologs), novērtēšana tika veikta klīniski (Sinko et al., 2005). Piemēram, Oti ar kolēgiem (2014) novērtēja apmierinātību ar bērna sejas izskatu pacientu vecāki, ķirurǵi un personas no malas. Šajā pētījumā intra un inter novērtētāja ticamība netika noteikta (Oti et al., 2014).

Tomēr ir raksti, kuros vairāki autori izmantoja VAS kā vienīgo estētikas novērtēšanas metodi ar labiem ticamības rezultātiem. Piemēram, Desmedt ar kolēgiem (2015) novērtēja deguna un lūpas simetriju trīsdimensiju fotoattēlos ar vizuālās analogu skalas palīdzību, kur 0 ir vissliktākais, bet 100 vislabākais estētiskais rezultāts. Mērījumus veica 8 rezidenti un dati tika salīdzināt ar modificētu Asher-McDade estētikas indeksu (Desmedt et al., 2015). Bongaarts ar kolēgiem (2008) izmantoja VAS lai salīdzinātu deguna estētikas novērtēšanu divdimensiju fotogrāfijās ar attēlotu tikai deguna un lūpas rajonu. Novērtēšanu veica profesionāļi un personas no malas, rezultāti uzrādīja labu intra un inter novērtētāja ticamību (Bongaarts et al., 2008). Ar pietiekoši labu intra un inter novērtētāja ticamības rezultātu Stebel ar kolēgiem (2016) izmantoja VAS, lai noteiktu deguna estētiku divdimensiju un 
trīsdimensiju fotoattēlos. Divdimensiju fotoattēlos intra un inter novērtētāja ticamība bija zemāka, nekā izmantojot VAS trīsdimensiju fotoattēlos (Stebel et al., 2016).

\subsubsection{Aptaujas}

Vairākos pētījumos tika pievērsta pastiprināta uzmanība psiholoǵiskajam stāvoklim bērniem ar iedzimtām lūpas un aukslēju šķeltnēm. Visbiežāk psiholoǵiskais stāvoklis tika novērtēts ar dažādām aptaujām un anketām, pašu pacientu, vecāku, apkārtējo cilvēku apmierinātība ar izskatu un estētiku. Izmantotie aptauju veidi atšks̄īās starp rakstiem. Piemēram, Noor un Musa (2007) izmantoja aptauju par runas, dzirdes, zobu izskatu, lūpas izskatu, deguna izskatu, elpošanu caur degunu, sejas profilu un sakodienu pēc 7 punktu skalas, kur 1 ir ļoti apmierina un 7 ļoti neapmierina. Gurley ar kolēgiem (2001) noteica pašu pacientu apmierinātību un salīdzināja to ar antropometriskiem mērījumiem divdimensiju fotoattēlos. Eksperti novērtēja pēc operāciju fotoattēlus izmantojot piecu punktu skalu un sagrupēja visus attēlus sākot no vairāk kā normāls, normāls, bez izmaiṇām, sliktāks kā normāls, l̦oti sliktāks kā normāls (Gurley et al., 2001). Pitak-Arnnop ar kolēgiem (2011) izmantoja vairākas aptaujas formas, pacienti sevi novērtēja pēc 4 punktu skalas, kur 1 - neapmierina, 2 - dal̦ēji apmierina, 3 - apmierina, 4 - ļoti apmierina, bet profesionāli novērtēja pēc 5 punktu skalas, kur 1 - uzlabojies, 2 - pasliktinājies, 3 - savādāks, bet nav uzlabojies, 4 - nav izmainījies, 5 - neskaidrs. Ar šīm aptaujām autori noteica divu ķirurğisko metožu rezultātus sekundārai rinoplastikai ar un bez kolumellas grafta (Pitak-Arnnop et al., 2011). Chetpakdeechit ar kolēgiem (2011) veica strukturētu aptauju un salīdzināja rezultātus ar profesionāļu un ne profesionāļu domām (skat. 1.15.att.). Oosterkamp ar kolēgiem (2007) izmantoja VAS, lai noteiktu pacientu apmierinātību un noteica dzīves kvalitātes rādītājus pēc Rand-36 aptaujas. Rand-36 ir ar veselību saistītas dzīves kvalitātes noteikšanas aptauja. Tā novērtē fizisko un sociālo funkcionēšanu, ierobežojumus saistībā ar fiziskiem un emocionāliem ierobežojumiem, dzīvīgumu, mentālo veselību, sāpes, dzīves uztveri un veselības izmaiņas. Katrai pozīcijai ir skala no 0-100, kur lielāks punktu skaits norāda labāku dz̄ives kvalitāti (Oosterkamp et al., 2007). Līdzīgi arī Roosenboom ar kolēgiem (2014) novērtēja šķeltņu pacientu pašvērtējumu un dzīves kvalitāti pēc sekundāras rinoplastikas. 

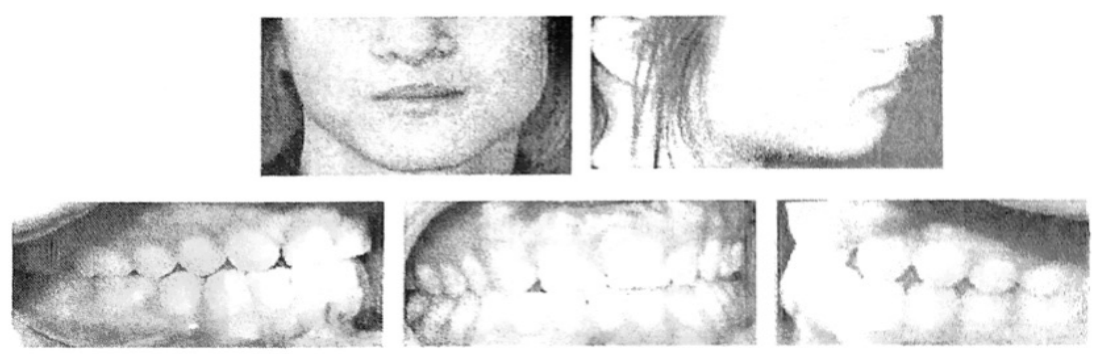

1. Kas ir pirmās trīs lietas, ko jūs pamaniet šīs personas izskatā? Uzrakstiet tās secīgi.

1)

2)

3)

2. Kā jūs novērtētu zemāk esošos punktus, lūdzu apvelciet ar aplīti.

1) sejas profils

slikti diezgan labi labi izcili

2) augšlūpas forma

3) augšējo zobu stāvoklis

4) apakšējo zobu stāvoklis

5) augšejo zobu forma

$\begin{array}{llll}0 & 0 & 0 & 0\end{array}$

6) augšējo zobu krāsa

$0 \quad 0$

$0 \quad 0$

$0 \quad 0$

$0 \quad 0$

$0 \quad 0$

7) kopējais izskats (visa seja)

0

0

$0 \quad 0$

$0 \quad 0$

$0 \quad 0$

$0 \quad 0$

$0 \quad 0$

3. Ja jums ir komentāri, lūdzu ierakstiet tos zemāk esošajā rāmītī;

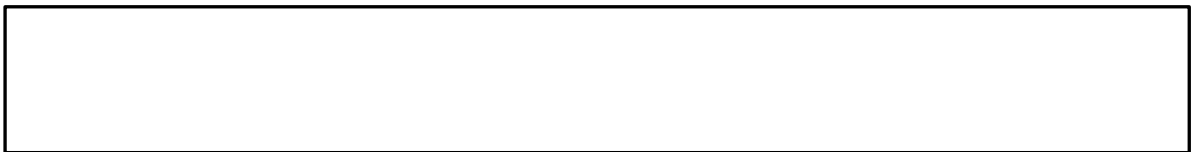

1.15. att. Strukturētas aptaujas piemērs (Chetpakdeechit et al., 2011) 


\section{MATERIĀLS UN METODES}

\subsection{Pētījuma dizains}

Pētījums tika veikts RSU SI Lūpu, aukslēju un sejas šķeltņu centrā un PSKUS 45. nodaļā Zobārstniecības un sejas ķirurǵijas centrā. Deguna estētikas novērtējums divdimensiju fotoattēlos bija retrospektīvs. Deguna elpošanas funkcijas novērtējums ar priekšēju rinomanometriju un deguna un augšlūpas simetrijas novērtējums 3D fotoattēlos bija šksērsgriezuma pētījums.

\subsection{Pētījuma ètiskie aspekti}

Pētījumam saņemta RSU Ētikas komitejas atḷauja (skat. 2. pielikums) un informētās piekrišanas aptauja no vecākiem un pilngadīgajiem pētījuma dalībniekiem (skat. 3., 4., 5. pielikums).

\subsection{Pētījuma kopa}

Mērķa populācija - bērni ar iedzimtu nesindromisku vienpusēju lūpas, alveolārā izauguma un aukslēju šķeltni.

Deguna estētikas noteikšanai 2D fotoattēlos tika veikta pacientu sistemātiskā atlase visi RSU SI Lūpu, aukslēju un sejas šķeltņu centrā reǵistrētie bērni ar vienpusēju lūpas, alveolārā izauguma un aukslēju šķeltni, kuriem veikta primāra lūpas un deguna plastika no 1995. gada 1. janvāra līdz 2008. gada 31. decembrim un kuri 2011. gadā bija sasnieguši 3 gadu vecumu. Pēc RSU SI Lūpu, aukslēju un sejas šķeltņu centra datu bāzes datiem tie bija 59 bērni.

Deguna elpošanas funkcijas un deguna un augšlūpas simetrijas novērtěšanai 3D fotoattēlos tika veikta pacientu sistemātiskā atlase - visi RSU SI Lūpu, aukslēju un sejas šķeltṇu centrā reǵistrētie un Latvijā dzimušie bērni no 1994. gada 1. janvāra līdz 2004. gada 31. decembrim (10-18 gadu vecumā) ar iedzimtu nesindromisku vienpusēju lūpas, alveolārā izauguma un aukslēju šķeltni. Pēc RSU SI Lūpu, aukslēju un sejas šķeltņu centra datu bāzes datiem tie bija 62 bērni. 
Iekḷaušanas kritēriji:

Bērni ar iedzimtu nesindromisku vienpusēju caurejošu lūpas, alveolārā izauguma un aukslēju škseltni, kuri:

1. Ir dzimuši Latvijā un reǵistrēti RSU SI Lūpu, aukslēju un sejas šķeltņu centrā.

2. Ir ārstēti ar atbilstošām ārstēšanas metodēm RSU SI Lūpu, aukslēju un sejas šķeltņu centrā.

3. Nav diagnosticēti ǵenētiski sindromi.

4. Kuriem ir pieejami 2D fotoattēli pretskata un kolumellas projekcijā 3 vai 5 gadu vecumā vai abos norādītajos vecumos (tikai deguna estētikas noteikšanai 2D fotoattēlos).

Izslēgšanas kritēriji:

1. Bērni ar iedzimtu vienpusēju nepilnu lūpas, alveolārā izauguma un aukslēju šķeltni vai ar Simonarta kroku.

2. Bērni ar vienpusēju caurejošu lūpas, alveolārā izauguma un aukslēju šķeltni, kuri ir miruši.

3. Bērni ar vienpusēju caurejošu lūpas, alveolārā izauguma un aukslēju šķeltni, kuri ir adoptēti uz ārzemēm vai emigrējuši.

4. Bērni ar vienpusēju caurejošu lūpas, alveolārā izauguma un aukslēju šķeltni, kuri ir dzimuši Latvijā, bet operēti citā valstī.

5. Bērni, kuriem nav pieejami kvalitatīvi fotoattēli ne 3 gadu vecumā, ne 5 gadu vecumā (tikai deguna estētikas noteikšanai 2D fotoattēlos).

Diagnoze tika apstiprināta ar fotoattēliem pirms primāras lūpas un deguna plastikas. Deguna estētikas noteikšanai 2D fotoattēlos pēc izslēgšanas kritērijiem pētījumā iekḷauti 27 bērni (11 meitenes un 16 zēni) ar vienpusēju caurejošu lūpas, alveolārā izauguma un aukslēju šķeltni, kuriem bija kvalitatīvi 2D fotoattēli pretskata un kolumellas projekcijā trīs gadu vecumā vai piecu gadu vecumā, vai abos norādītajos vecumos. Pētījumā iekḷautajiem bērniem šķeltne 20 gadījumos atradās kreisajā pusē, bet 7 gadījumos labajā pusē. No pētījuma izslēgti 32 bērni, no tiem 14 bērni ar vienpusēju nepilnu lūpas, alveolārā izauguma un aukslēju šķeltni, 4 bērni ar Simonarta kroku, 1 bērns, kurš bija miris nesasniedzot 3 gadu vecumu, 3 bērni, kuri bija adoptēti uz ārzemēm vai emigrējuši līdz 3 gadu vecumam, 10 bērni, kuriem nebija pieejami vai nebija kvalitatīvi 2D fotoattēli ne 3 gadu, ne 5 gadu vecumā. 
Deguna elpošanas funkcijas un deguna un augšlūpas simetrijas novērtēšanai 3D fotoattēlos pēc izslēgšanas kritērijiem pētījumā iekḷauti 35 bērni ar vienpusēju caurejošu lūpas, alveolārā izauguma un aukslēju šķeltni. No iekḷautajiem 35 bērniem uz kontroli atnāca 30 (15 meitenes un 15 zēni) deguna elpošanas funkcijas un simetrijas noteikšanai un salīdzināšanai 3D fotoattēlos (pētîjuma grupa). Šķ̧eltne 21 gadījumā atradās kreisajā pusē, bet 9 gadījumos labajā pusēe, vidējais bērna vecums bija 14 gadi, robežās no 10-18 gadiem. No pētījuma izslēgti 27 bērni, no tiem 13 bērni ar vienpusēju nepilnu lūpas, alveolārā izauguma un aukslēju škseltni, 4 bērni ar Simonarta kroku, 5 bērni, kuri bija miruši, 3 bērni, kuri bija adoptēti uz ārzemēm vai emigrējuši, 2 bērni, kuri operēti citā valstī.

Kontroles grupā iekḷauti pirmie 35 veseli bērni 10 gadu vecumā (18 zēni, 17 meitenes), kuri bija atnākuši piedalīties RSU Stomatologijas institūtā notiekošajā sejas augšanas novērtēšanas pētījumā un kuri piekrita piedalīties arī šajā pētîjumā.

\subsection{Metodes apraksts deguna estētikas noteikšanai 2D fotoattēlos}

Tika veikta pētījumā iekḷauto 27 bērnu 2D fotoattēlu analīze un sagatavošana deguna estētikas novērtēšanai. No pētījumā iekḷautajiem 27 bērniem kvalitatīvi un deguna estētikas novērtēšanai derīgi 2D fotoattēli 3 gadu vecumā bija 23 bērniem, no kuriem tika izveidoti 23 fotoattēlu pāri pretskata un kolumellas projekcijā. Savukārt 2D fotoattēli 5 gadu vecumā deguna estētikas novērtēšanai bija derīgi 20 bērniem, no kuriem tika izveidoti attiecīgi 20 fotoattēlu pāri. Fotoattēli tika sagatavoti pēc vienotas sistēmas - melnbalti, izgriezti trīsstūri, kuros redzami tikai deguns un lūpas (skat. 2.1. att.). Visos fotoattēlos šķeltne tika pozicionēta vienā lūpas pusē - sākumā kreisajā, bet pēc tam labajā pusē (skat. 2.2. att.). Fotoattēlu pāri, kuri sastāvēja no viena bērna pretskata un kolumellas projekcijas 2D fotoattēliem, anonīmi, kodēti, sajauktā secībā tika ievietoti power point prezentācijā. 


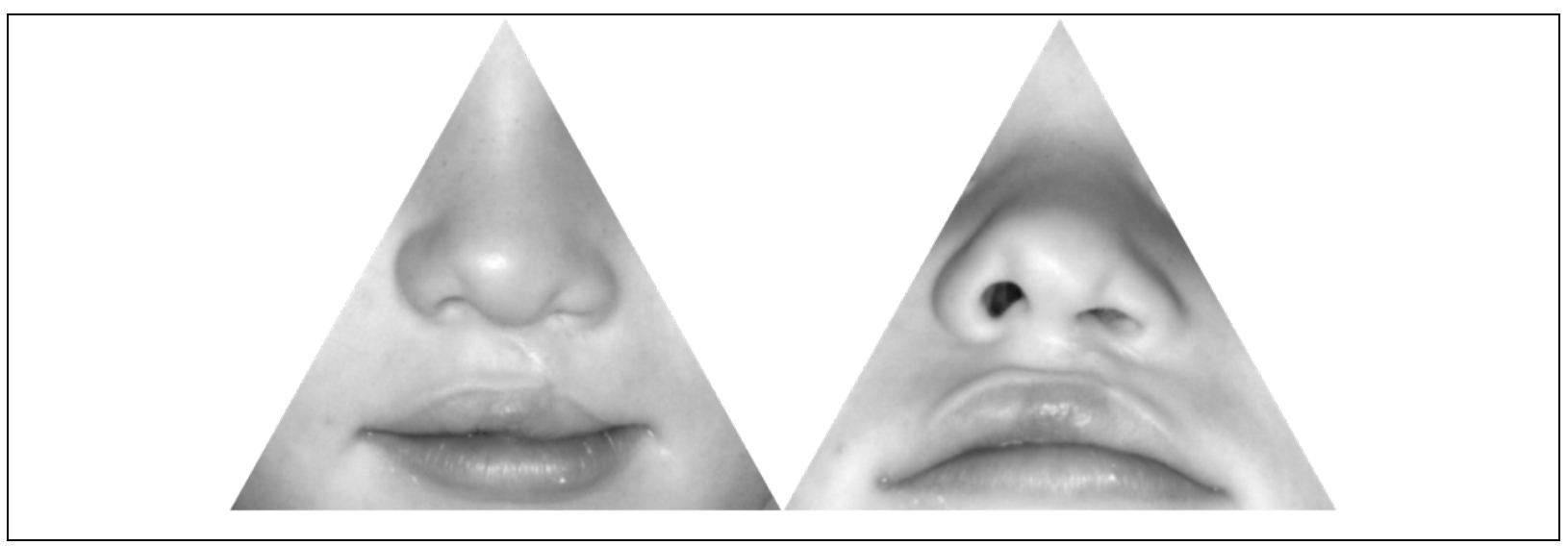

2.1. att. Deguna estētikas novērtēšanas 2D fotoattēlu pāris 3 gadu vecumā, šķeltnei atrodoties kreisajā pusē

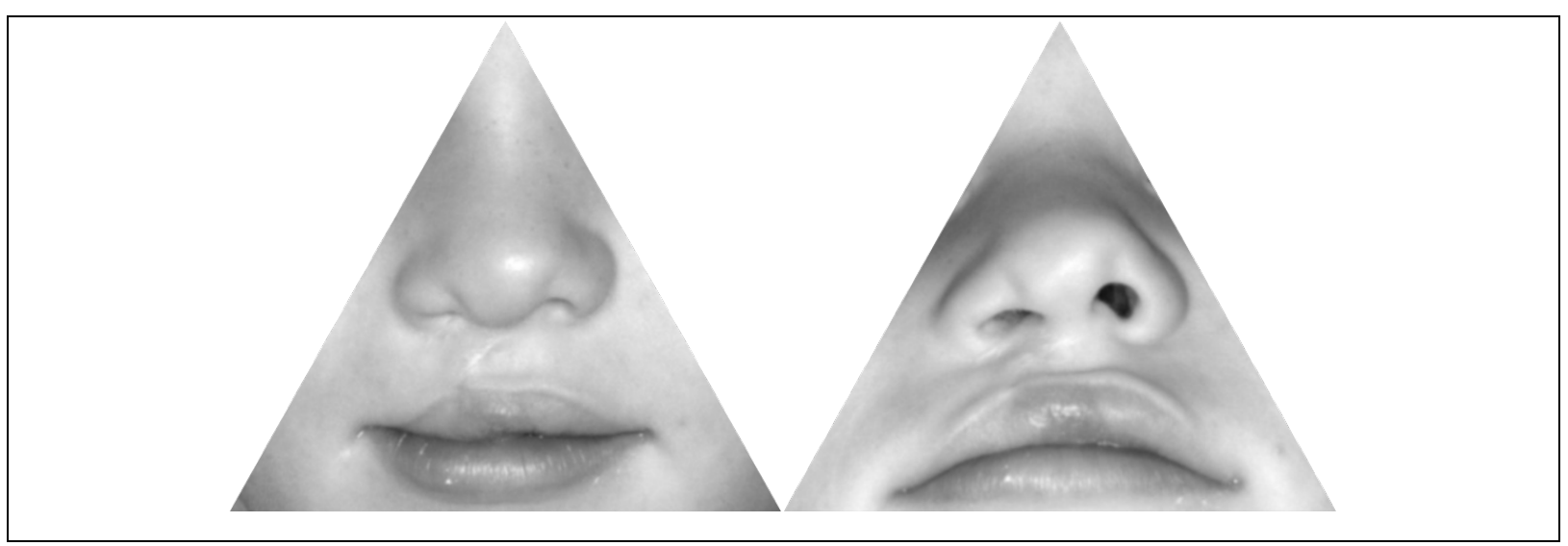

2.2. att. Deguna estētikas novērtēšanas $2 \mathrm{D}$ fotoattēlu pāris 3 gadu vecumā, šķeltnei atrodoties labajā pusēe

Deguna estētikas novērtēšanai 2D fotoattēlos tika izmantota modificēta un pielāgota Anastassov un Chipkov (2003) izstrādātā deguna estētikas vērtēšanas skala un vizuālo analogu skala (VAS). Pirms vērtēšanas eksperti tika iepazīstināti ar attēliem un sagatavoti vērtēšanai. Katrs attēlu pāris tika novērtēts vienu minūti pēc modificētas Anastassov un Chipkov (2003) izstrādātās klīniskas vērtēšanas skalas, kura īpaši pielāgota deguna deformāciju novērtēšanai 2D fotoattēlos pacientiem ar vienpusēju caurejošu lūpas, alveolārā izauguma un aukslēju šķeltni (skat. 2.1. tab.). Šì deguna estētikas novērtēšanas skala sastāv no 13 deguna deformācijas pazīmēm, kuras novērtētas ar negatīviem punktiem no 0,5-3, kas atspoguḷo deguna deformācijas smaguma pakāpes. Pēdējā pozīcija šajā skalā ir "Summa", kas ataino kopējo deguna deformācijas smaguma pakāpi, jo vairāk punkti tiek atzīmēti konkrētajā 2D fotoattēlu pārī, jo vairāk deformēts ir bērna deguns. Kopumā novērtēšanu veica četras reizes divi novērtētāji (autors un mutes, sejas un žokļu ķirurgs, kurš operē šķeltnes). Divas reizes novērtēšana veikta, kad šķeltne atradās kreisajā pusē un divas reizes labajā pusē. Katra novērtēšana veikta ar vienas nedēḷas intervālu. 
Modificēta Anastassov un Chipkov (2003) deguna estētikas novērtēšanas skala

\begin{tabular}{|c|c|c|c|}
\hline $\mathrm{Nr}$. & Pozīcija & Shematisks attēls & Punkti \\
\hline 1 & Simetrisks deguns & & 0 \\
\hline 2 & Kolumella pārāk īsa & (92) & 0,5 \\
\hline 3 & $\begin{array}{l}\text { Redzama starpsienas subluksācija vai } \\
\text { deviācija }\end{array}$ & gas & 1 \\
\hline 4 & Plata nāsu pamatne & 20 & 0,5 \\
\hline 5 & Šaura nāsu pamatne & & 0,5 \\
\hline 6 & Kolumellas pamatne pārāk plata & & 0,5 \\
\hline 7 & Kolumellas pamatne pārāk šaura & & 0,5 \\
\hline 8 & Nepietiekoša spārna ieloce & & 0,5 \\
\hline 9 & Pārāk izteikta spārna ieloce & & 0,5 \\
\hline 10 & Nāsu augšējās malas deformācija & & 0,5 \\
\hline 11 & Spārna skrimšla nepareiza pozīcija & & 1 \\
\hline 12 & Spārna augsta pozīcija & s & 0,5 \\
\hline 13 & Spārna zema pozīcija & q & 0,5 \\
\hline 14 & Saplacināts un hipoplastisks spārns & Q⿱日一) & 3 \\
\hline 15 & Summa & & \\
\hline
\end{tabular}

Deguna estētikas novērtēšanai 2D fotoattēlu komplektos ar vizuālo analogu skalu (VAS), tika izmantoti vertikāli, bez iedaļu, $100 \mathrm{~mm}$ gari stabiņi, kuros augšpusē norādīts „simetrisks deguns, bez deformācijas”, apakšā „lielāka deformācija nav iedomājama” (skat. 2.3. att.). Novērtēšanu veica power point prezentācijā ievietotajos attēlos, katru 10 sekundes. Vērtēšanā piedalījās 4 vērtētāji: A - mutes, sejas un žokḷu ķirurgs, kurš operē šķeltnes, B - autors, F - plastikas ķirurgs, kurš šķeltnes neoperē un $\mathrm{G}$ - klīnikas administratore. Mērījumi veikti vienu reizi attēlos, kur visas šķeltnes pagrieztas uz kreiso pusi un vienu reizi, kur pagrieztas uz labo pusi, abus mērījumus atkārtojot ar vienas nedēḷas intervālu. 


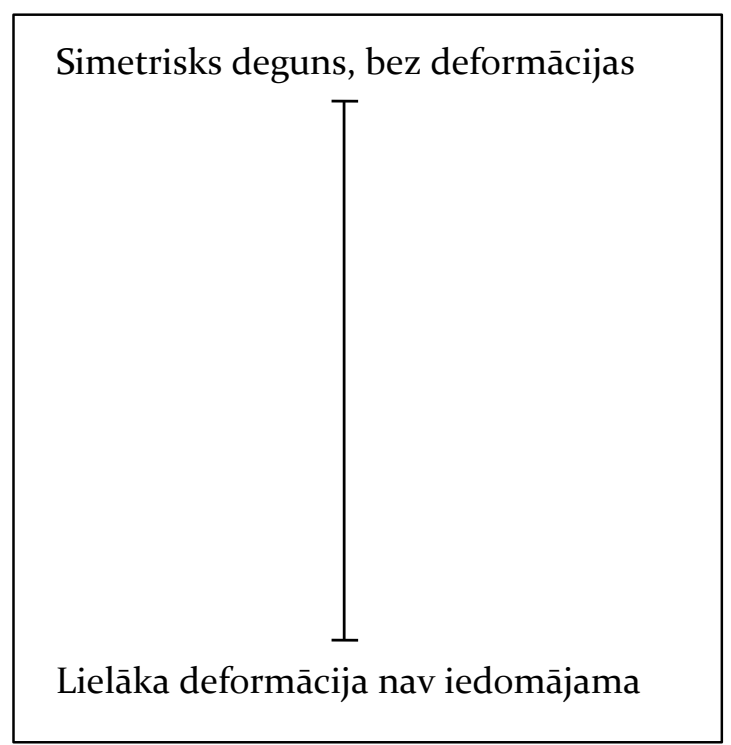

2.3. att. Vizuālā analogu skala

\subsection{Elpošanas funkcijas metodes apraksts}

Deguna elpošanas funkcijas noteikšanai pētījuma un kontroles grupām tika veikta priekšēja rinomanometrija ar Otopront kombinētu rinomanometrijas un akustiskās rinometrijas ierīci RHINO-SYS (Happersberg otopront GmbH, Vācija). Datu mērīšanas programmas RHINO-BASE un RHINO-ACOUSTIC. Bērniem ar iedzimtu vienpusēju caurejošu lūpas, alveolārā izauguma un aukslēju škeltni rinomanometrijas izmeklējums veikts ne ātrāk kā 6 mēnešus pēc pēdējās deguna korekcijas (bez un ar dekongestantu (deguna pilieni Xymelin $0,1 \%$ ) pēc vispārējiem standartiem). Elpošanas plūsmas smaguma pakāpe tika noteikta pēc Bachmann gradācijas (Bachmann, 1983) (skat. 2.2.tab.).

2.2. tabula

Deguna obstrukcijas gradācijas pakāpes vienai nāsij pēc Bachmann (1983)

\begin{tabular}{|l|l|}
\hline \multicolumn{1}{|c|}{ Deguna obstrukcijas pakāpe } & \multicolumn{1}{|c|}{ Elpošanas plūsma $[\mathrm{cm} 3 / \mathrm{s}]$ pie $150 \mathrm{~Pa}$} \\
\hline Nav obstrukcijas & $>500$ \\
\hline Viegla obstrukcija & $300-500$ \\
\hline Vidēja obstrukcija & $180-300$ \\
\hline Smaga obstrukcija & $<180$ \\
\hline
\end{tabular}




\subsection{D stereo-fotogrammetrijas metodes apraksts}

Trīsdimensiju stereo-fotometrisks izmeklējums sejas virsmas topogrāfiskas anatomijas un krāsu tekstūras iegūšanai tika veikts ar 3dMD face System (3dMD face System; $3 d M D$ LLC, Atlanta, GA). Iekārta sastāv no sešām kamerām un iestrādātu zibspuldzi, kas sinhronizēta ar attēla uzņemšanu. Pēc kalibrēšanās, kompjūters uzsāk sēriju ar attēlu uzņemšanu no abām sejas pusēm, 180 grādu sejas uzṇēmums (no auss līdz ausij). Šis process aizņem 1,5 milisekundes. Pēc ekspozīcijas tiek izveidoti 6 attēli (katrai pusei divi melnbalti un viens krāsains attēls) no kuriem tiek rekonstruēta trīsdimensiju fotogrāfija.

Veicot 3D fotoattēla uzņemšanu, persona tika apsēdināta uz krēsla $90 \mathrm{~cm}$ fiksētā attālumā no kameras dabīgā galvas pozīcijā un ieraduma sakodienā. Dalībniekiem tika lūgts atslābināt sejas muskulatūru, norīt siekalas un saglabāt pozīcijā sakostus dzerokḷus (van Loon et al., 2010). Bērniem ar vienpusēju caurejošu lūpas, alveolārā izauguma un aukslēju šķeltni 3D fotoattēli uzṇemti ne âtrāk kā 6 mēnešus pēc pēdējās deguna korekcijas.

\subsection{Antropometrija}

Antropometrisko punktu atlikšanai 3D fotoattēlos tika izmantota 3dMD Vultus software programma (3dMD Vultus Software Platform, 3dMD LLC, Atlanta, USA). Punktu atlikšana attēlā automātiski ğenerē X, Y un Z koordinātes, kas ataino sejas pazīmju telpisko orientāciju. Pirms antropometrijas veikšanas, visi 3D fotoattēli tika apstrādāti tā, lai šķeltne atrastos kreisajā pusē. Pēc tam tika atlikti 25 antropometriski punkti un izmērīti 18 lineāri attālumi galvenokārt pamatojoties no Farkas ar kolēǵiem (1993) pētījuma ar modifikācijām pēc Hood ar kolēgeiem (2004) un van Loon ar kolēǵiem (2010) (skat. 2.4. att., 2.3. tab. un 2.4. tab.). Antropometriskie punkti 3D fotoattēlos tika atlikti manuāli izmantojot 3dMD Vultus software programmu. Mīksto audu anatomisko punktu atskaites vertikālā plakne Y tika pozicionēta caur glabella un nasion, horizontālā plakne X tika pozicionēta caur labo un kreiso endokantu (Verzé et al., 2014). Lai noteiktu intra - novērtētāja ticamību, visi mērījumi tika veikti divas reizes ar vienas nedēlas intervālu. 


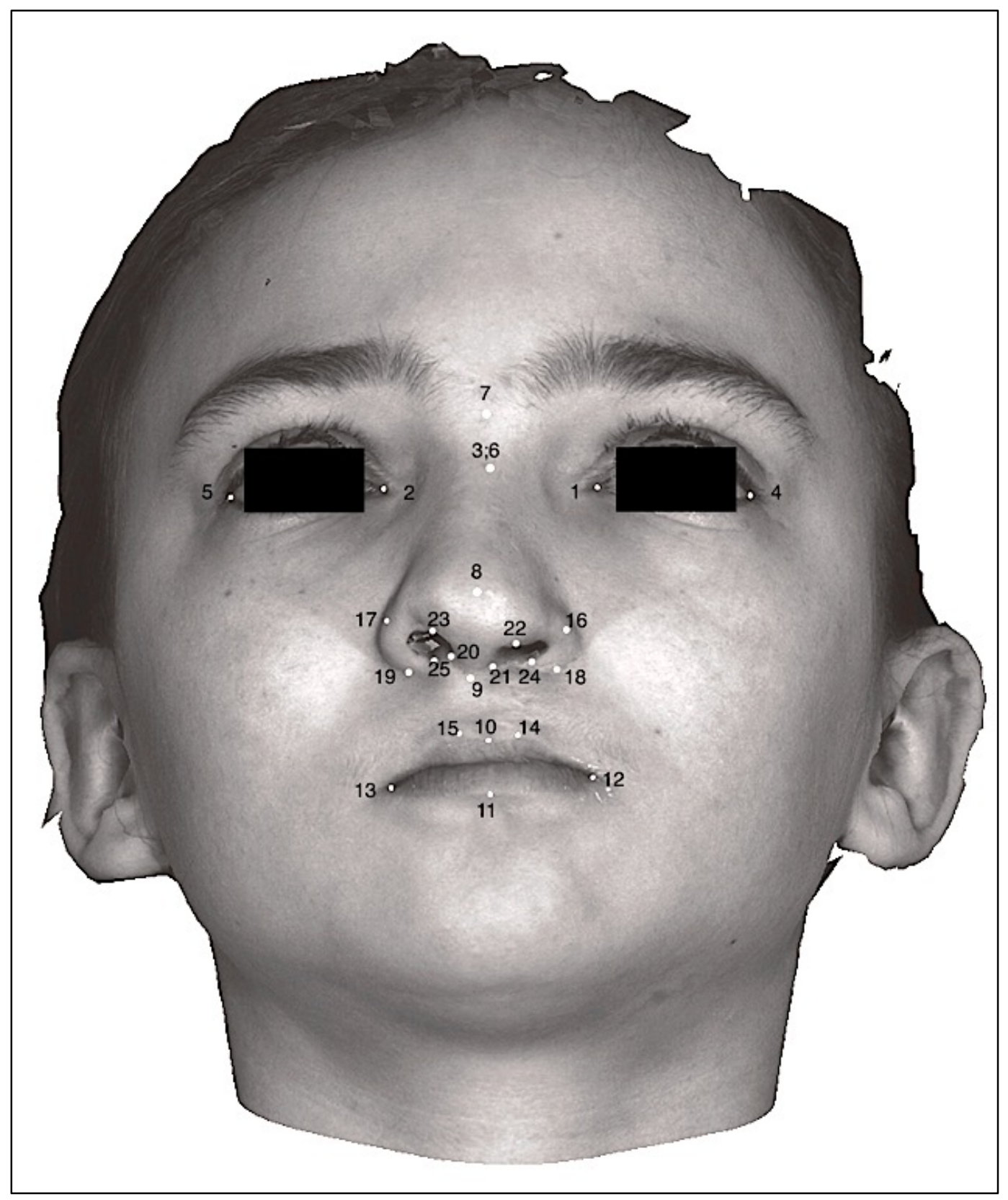

2.4. att. 3D fotoattēls ar atliktiem 25 antropometriskiem punktiem 
Antropometriskie punkti un to skaidrojums

\begin{tabular}{|c|c|c|}
\hline Nr. & Antropometriskie punkti & Saīsinājums \\
\hline 1. & Endokants (kreisais) & en $(\mathrm{L})$ \\
\hline 2. & Endokants (labais) & en(R) \\
\hline 3. & Endokants (viduspunkts) & en(M) \\
\hline 4. & Eksokants (kreisais) & $\operatorname{ex}(\mathrm{L})$ \\
\hline 5. & Eksokants (labais) & $\mathrm{ex}(\mathrm{R})$ \\
\hline 6. & Nasion & $\mathrm{N}$ \\
\hline 7. & Glabella & $\mathrm{G}$ \\
\hline 8. & Pronasale & PRN \\
\hline 9. & Subnasale & $\mathrm{Sn}$ \\
\hline 10. & Augšlūpa (viduspunkts) & $\operatorname{ch}(\mathrm{M})$ \\
\hline 11. & Apakšlūpa (viduspunkts) & ch(M)lower \\
\hline 12. & Lūpu kaktinšs (kreisais) & $\operatorname{ch}(\mathrm{L})$ \\
\hline 13. & Lūpu kaktiņš (labais) & $\operatorname{ch}(\mathrm{R})$ \\
\hline 14. & Lūpu loka augšējais punkts (kreisais) & $\mathrm{Cph}(\mathrm{L})$ \\
\hline 15. & Lūpu loka augšejais punkts (labais) & $\mathrm{Cph}(\mathrm{R})$ \\
\hline 16. & Deguna spārns (kreisais) & $\mathrm{al}(\mathrm{L})$ \\
\hline 17. & Deguna spārns (labais) & $\mathrm{al}(\mathrm{R})$ \\
\hline 18. & Deguna spārna apakšējais punkts (kreisais) & $\operatorname{Sbal}(\mathrm{L})$ \\
\hline 19. & Deguna spārna apakšejais punkts (labais) & $\operatorname{Sbal}(\mathrm{R})$ \\
\hline 20. & Kolumellas pamatne (labā puse) & $\mathrm{Sn} 0(\mathrm{R})$ \\
\hline 21. & Kolumellas pamatne (kreisā puse) & $\mathrm{Sn} 0(\mathrm{~L})$ \\
\hline 22. & Nāss augstākais punkts (kreisais) & $\operatorname{nd}(\mathrm{L})$ \\
\hline 23. & Nāss augstākais punkts (labais) & $\mathrm{nd}(\mathrm{R})$ \\
\hline 24. & Nāss zemākais punkts (kreisais) & $\mathrm{nl}(\mathrm{L})$ \\
\hline 25. & Nāss zemākais punkts (labais) & $\mathrm{nl}(\mathrm{R})$ \\
\hline
\end{tabular}

\section{Antropometriskie attālumi un to skaidrojums}

\begin{tabular}{|c|c|c|}
\hline $\mathrm{Nr}$. & Saīsinājums & Apraksts \\
\hline 1. & cphR-chM & Lūpas loka attālums līdz viduslīnijai labajā pusē \\
\hline 2. & cphL-chM & Lūpas loka attālums līdz viduslīnijai kreisajā pusē \\
\hline 3. & chR-cphR & Lūpas garums līdz lūpu lokam labajā pusē \\
\hline 4. & chL-cphL & Lūpas garums līdz lūpu lokam kreisajā pusē \\
\hline 5. & SbalR-cphR & Baltās lūpas garums labajā pusē \\
\hline 6. & SbalL-cphL & Baltās lūpas garums kreisajā pusē \\
\hline 7. & nlR-ndR & Nāss augstums labajā pusē \\
\hline 8. & nlL-ndL & Nāss augstums kreisajā pusē \\
\hline 9. & alR-Sn & Nāss platums labajā pusē \\
\hline 10. & alL-Sn & Nāss platums kreisajā pusē \\
\hline 11. & alR-N & Deguna sāna garums labajā pusē \\
\hline 12. & alL-N & Deguna sāna garums kreisajā pusē \\
\hline 13. & alR-PRN & Deguna spārna garums labajā pusē \\
\hline 14. & alL-PRN & Deguna spārna garums kreisajā pusē \\
\hline 15. & alR-alL & Deguna platums \\
\hline 16. & SbalR-SbalL & Deguna pamatnes platums \\
\hline 17. & PRN-N & Deguna muguriņas garums \\
\hline 18. & PRN-Sn & Deguna augstums \\
\hline
\end{tabular}




\subsection{Simetrijas indekss}

Deguna un augšlūpas mērījumiem 3D fotoattēlos tika pielāgots Amaratunga (1988) izmantotais šķeltņu lūpas komponenta simetrijas indekss (CLCSI - cleft lip component symmetry index), turpmāk tekstā - simetrijas indekss. Simetrijas indekss tika aprēķināts pēc formulas - attālums šķeltnes pusē pret attālumu veselajā pusē reizinot ar 100. Perfektu simetriju raksturotu vērtība 100, bet vērtība mazāka, vai lielāka par 100 raksturotu asimetrijas pakāpi. Pēc $L i$ ar kolēgiem (2010) ķirurg̣ijas rezultāts bija izdevies, ja estētikas indekss degunam un augšlūpai bija robežās no 90-110\% (Li et al., 2010).

\subsection{Datu statistiskā analīze}

Mērījumiem divdimensiju fotoattēlos ar modificēto un pielāgoto Anastassov un Chipkov (2003) izstrādāto deguna estētikas vērtēšanas skalu tika noteikta metodes ticamības analīze, nosakot Kappa koeficientu un vienprātības procentuālo sakritību. Ja Kappa 0,8-1,0 ticamība ļoti laba, 0,6-0,8 laba, 0,4-0,6 vidēja, 0,2-0,4 slikta, < 0,2 ļoti slikta (Landis \& Koch, 1977). Vizuālās analogu skalas rezultāti salīdzināti ar ANOVA testu, kur statistiskās ticamības robeža bija $\mathrm{p}<0,05$.

Deguna elpošanas funkcijas datu statistiskai apstrādei izmantotas aprakstošās statistikas metodes. Lai pētījuma grupā noteiktu atšķirību elpošanas plūsmai starp šķeltnes un veselo pusi un kontroles grupā starp labo un kreiso pusi, tika izmantots paired $t$ tests ar statistiskās ticamības robežu $p<0,05$. Lai noteiktu atšķirību elpošanas plūsmai starp pētījuma grupu un kontroles grupu tika izmantots unpaired $t$ tests ar statistiskās ticamības robežu $\mathrm{p}<0,05$.

Mērījumiem trīsdimensiju fotoattēlos, lai noteiktu mērījuma kḷūdu tika izmantota Dahlberg formula (Dahlberg, 1940), kur mērījuma kḷūda tika uzskatīta par pieņemamu, ja tā nepārsniedza 3\% no kopējās dispersijas. Tika lietota aprakstošā statistika, kā mērījumu vidējo rādītāju un standartnovirzes aprēķināšana. Lai noteiktu izmērīto attālumu atšķirību starp šķeltnes un ne šķeltnes pusi, tika izmantots Wilcoxon signed rank tests, bet Mann-Whitney tests, lai salīdzinātu pêtījuma grupu ar kontroles grupu, kur statistiskās ticamības robeža $\mathrm{p}<0,05$. Paired $t$ tests tika izmantots indeksu salīdzināšanai ar vērtību 100, lai noteiktu statistiski ticamu asimetrijas pakāpi starp šķeltnes un veselo pusi pētījuma grupā un labo un kreiso pusi kontroles grupā. Unpaired $t$ tests tika izmantots, lai noteiktu statistiski ticamu atšķirīibu starp pētījuma grupu un kontroles grupu ar statistiskās ticamības robežu $p<0,05$. Lai noteiktu saistību starp elpošanas funkciju un deguna simetriju, tika izmantots ANOVA tests 
ar Bonferroni korekciju. Bonferroni korekcija tika izmantota, lai kontrolētu otrā tipa kḷūdu katrā salīdzinājuma grupā. Statistiskās ticamības robeža šajā testā tika noteikta $p<0,05$.

\subsection{0. Ķirurğiskā ārstēšana}

Visus pētījumā iekḷautos bērnus ar vienpusēju caurejošu lūpas, alveolārā izauguma un aukslēju šķeltni bija operējuši divi mutes, sejas un žokḷu ķirurgi. Primāra lūpas plastika tika veikta, lietojot Millard rotācijas metodi (Millard Jr, 1976). Caur šĩ dizaina griezienu tika veikta vienlaicīga primāra deguna korekcija, kuras laikā pilnībā tika mobilizēta deguna spārna pamatne šķeltnes pusē. Lai atbrīvotu lūpas laterālo malu un muskulatūru šķeltnes pusē, tika veikta supraperiostāla preparēšana līdz infraorbitālā nerva līmenim. Deguna starpsienas skrimšl̦ainās daļas repozīcija, bez papildu fiksācijas tika uzsākta kopš 2001. gada 1. janvāra visiem bērniem ar iedzimtu vienpusēju caurejošu lūpas, alveolārā izauguma un aukslēju šķeltni primāras lūpas un deguna plastikas laikā. Sekundāra deguna korekcija tika veikta ar vaļēju pieeju un ietvēra starpsienas un apakšējā laterālā skrimšla repozīciju un fiksāciju.

Pētījuma daḷā, kurā noteikta deguna estētika 2D fotoattēlos, lūpas plastika tika veikta vidēji 6,3 mēnešu vecumā (diapazonā no 2-24 mēnešiem). Primāra starpsienas skrimšlainās daḷas repozīicija, bez papildu fiksācijas tika veikta 15 bērniem. No pētîjumā iekḷautajiem bērniem trīs un piecu gadu vecumā, nevienam netika veikta sekundāra deguna korekcija pirms deguna estētikas novērtēšanas $2 \mathrm{D}$ fotoattēlos.

Pētījuma daḷā, kurā noteikta deguna elpošanas funkcija un deguna un augšlūpas simetrija 3D fotoattēlos, lūpas plastika tika veikta vidēji 6,6 mēnešu vecumā (diapazonā no 3-24 mēnešiem). Sekundāra deguna korekcija pirmsskolas vai agrīnas skolas vecumā tika veikta 26 bērniem. Vidējais vecums sekundārai deguna korekcijai bija 7,8 gadi (robežās 6-10 gadi). Sekundāras deguna korekcijas laikā pirmsskolas vecuma bērniem, piecos gadījumos veikta ar̄̄ augšlūpas korekcija. Četrpadsmit gadījumos tika veiktas vairākas deguna korekcijas, līdz rezultāts tika uzskatīts par apmierinošu gan no pacientu, gan apkārtējo viedokḷa. Četriem pētījuma pacientiem tika veikta tikai primāra lūpas un deguna plastika, bez sekundāras deguna korekcijas, no kuriem 2 pacientiem pie primāras plastikas tika veikta arī starpsienas repozīcija. Vienam bērnam sekundāra deguna korekcija netika veikta, jo bērns ilgstoši nebija ieradies uz atkārtotām kontrolēm Lūpu, aukslēju un sejas škseltņu centrā. Otram bērnam sekundāra deguna korekcija tika atlikta vispārēju saslimšanu dēḷ, bet pārējiem diviem bērniem tika uzskatīts, ka elpošanas funkcija un estētika bija apmierinoša pēc primāras lūpas un deguna plastikas ar starpsienas repozīciju. 


\section{REZULTĀTI}

\subsection{Deguna estētikas novērtēšana 2D fotoattēlos ar modificēto Anastassov un Chipkov (2003) skalu}

Novērtējot deguna estētiku ar pielāgoto un modificēto Anastassov un Chipkov (2003) novērtēšanas skalu, rezultātu summa svārstījās no 0 līdz 3 punktiem. Tādas deformācijas kā “šaura nāsu pamatne", "kolumellas pamatne pārāk šaura", "saplacināts un hipoplastisks spārns" nevienam pacientam netika atzīmēts. Visbiežāk tika atzīmētas "nāsu augšējās malas deformācija" un "plata nāsu pamatne”, bet novērtētāju domas šajās pozīcijās visvairāk atškīirās (novērtētāju variabilitāte bija visaugstākā) (skat. 3.1. tab. un 3.2. tab.). Tā kā pētījumā iekḷautā grupa bija salīdzinoši maza, tad dažos gadījumos Kappa koeficientu nebija iespējams aprēķināt, jo skaitl̦i bija pārāk mazi, tad jāṇem vērā tikai vienprātības procentuālā sakritība. Tika noteikta intra novērtētāja variabilitāte A un B novērtētājam mērījumiem škseltnei atrodoties kreisajā pusē un labajā pusē (skat. 3.1. tab.). Vietām Kappa ir zem 0,4, kas norāda par zemu vienprātību, bet ir pozīcijas, kur Kappa ir 1, kas norāda par l̦oti labu ticamību, piemēram, "simetrisks deguns", "šaura nāsu pamatne", "kolumellas pamatne pārāk plata vai šaura", "saplacināts un hipoplastisks spārns". Abās mērījumu reizēs, abi novērtētāji šīs pozīcijas atzīmēja vienādi, šķeltnei atrodoties gan kreisajā pusē, gan labajā pusē. Novērtējot attēlus, kur šķeltne atradās kreisajā pusē, intra novērtētāja Kappa koeficients A novērtētājam svārstījās no 0,2-1,0, bet B novērtētājam no 0,1-1,0. Šķeltnei atrodoties labajā pusē, A novērtētāja Kappa svārstījās no $0,1-1,0$, bet B novērtētājam no $0,4-1,0$. Novērtētāju A un B intra variabilitāte bija līdzịga. Vairākumā novērtējuma pozīciju, Kappa atradās robežās no 0,5-1,0, kas norāda par vidēju līdz ļoti labu ticamību (skat. 3.1. tab.). Ir tādas modificētās Anastassov un Chipkov (2003) novērtēšanas skalas pozīcijas, kuru noteikšana atšķīrās katrā no mērījumiem (Kappa ar l̦oti sliktu līdz vidēju ticamību no 0,1-0,6), piemēram, "nāsu augšējās malas deformācija" un "spārna skrimšlı nepareiza pozīcija”. 
Intra novērtētāja variabilitāte A un B novērtētājam mērījumiem škseltnei atrodoties kreisajā (sin) pusē un labajā (dx) pusē

\begin{tabular}{|c|c|c|c|c|c|c|c|c|c|}
\hline \multirow[b]{2}{*}{$\mathrm{Nr}$. } & \multirow{2}{*}{$\begin{array}{c}\text { Modificētas Anastassov } \\
\text { un Chipkov (2003) } \\
\text { novērtēšanas skalas } \\
\text { pozīcija }\end{array}$} & \multicolumn{2}{|c|}{$A \sin$} & \multicolumn{2}{|c|}{$\mathrm{B} \sin$} & \multicolumn{2}{|c|}{$\mathrm{Adx}$} & \multicolumn{2}{|c|}{$\mathrm{Bdx}$} \\
\hline & & $\%$ & Kappa & $\%$ & Kappa & $\%$ & Kappa & $\%$ & Kappa \\
\hline 1. & Simetrisks deguns & 100 & 1,0 & 100 & 1,0 & 100 & 1,0 & 100 & 1,0 \\
\hline 2. & Kolumella pārāk îsa & 90,7 & 0,8 & 90,7 & 0,8 & 74,4 & 0,2 & 86,1 & 0,7 \\
\hline 3. & $\begin{array}{l}\text { Redzama starpsienas } \\
\text { subluksācija vai } \\
\text { deviācija }\end{array}$ & 97,7 & 0,9 & 86,1 & 0,6 & 97,7 & 0,9 & 95,4 & 0,8 \\
\hline 4. & Plata nāsu pamatne & 74,4 & 0,5 & 79,1 & 0,6 & 60,5 & 0,1 & 83,7 & 0,6 \\
\hline 5. & Šaura nāsu pamatne & 100 & 1,0 & 100 & 1,0 & 100 & 1,0 & 100 & 1,0 \\
\hline 6. & $\begin{array}{l}\text { Kolumellas pamatne } \\
\text { pārāk plata }\end{array}$ & 100 & 1,0 & 93,0 & 1,0 & 100 & 1,0 & 100 & 1,0 \\
\hline 7. & $\begin{array}{l}\text { Kolumellas pamatne } \\
\text { pārāk šaura }\end{array}$ & 100 & 1,0 & 100 & 1,0 & 100 & 1,0 & 100 & 1,0 \\
\hline 8. & $\begin{array}{l}\text { Nepietiekoša spārna } \\
\text { ieloce }\end{array}$ & 90,7 & 0,8 & 88,4 & 0,8 & 100 & 1,0 & 88,4 & 0,7 \\
\hline 9. & $\begin{array}{l}\text { Pārāk izteikta spārna } \\
\text { ieloce }\end{array}$ & 97,7 & 0,9 & 76,7 & 0,5 & 93,0 & NA* & 95,4 & 0,6 \\
\hline 10. & $\begin{array}{l}\text { Nāsu augšējās malas } \\
\text { deformācija }\end{array}$ & 93,0 & 0,5 & 88,4 & 0,7 & 57,1 & 0,1 & 85,7 & 0,7 \\
\hline 11. & $\begin{array}{l}\text { Spārna skrimšla } \\
\text { nepareiza poz̄icija }\end{array}$ & 72,1 & 0,4 & 83,7 & 0,5 & 81,4 & 0,4 & 93,0 & 0,8 \\
\hline 12. & Spārna augsta pozīcija & 100 & 1,0 & 93,0 & 0,6 & 88,4 & 0,4 & 95,4 & 0,6 \\
\hline 13. & Spārna zema pozīcija & 86,1 & 0,2 & 97,7 & 0,8 & 95,4 & 0,6 & 95,4 & 0,6 \\
\hline 14. & $\begin{array}{l}\text { Saplacināts un } \\
\text { hipoplastisks spārns }\end{array}$ & 100 & 1,0 & 100 & 1,0 & 100 & 1,0 & 100 & 1,0 \\
\hline 15. & Summa & 46,5 & 0,3 & 30,2 & 0,1 & 53,5 & 0,4 & 58,1 & 0,4 \\
\hline
\end{tabular}

*NA - Kappa nav aprēķināms. Ja Kappa 0,8-1,0 ticamība ļoti laba, 0,6-0,8 laba, 0,4-0,6 vidēja, 0,2-0,4 slikta, $<0,2$ loti slikta

Lai noteiktu metodes ticamību starp vairākiem novērtētājiem, tika noteikts Kappa koeficients starp A un B novērtētāju pēc atkārtotiem mērījumiem šķeltnei atrodoties kreisajā pusē un labajā pusē (skat. 3.2. tab.). Mērījumi tika veikti divas reizes ar vienas nedēḷas intervālu. Līdzīgi kā intra novērtētāju Kappa rādītāji, arī šajos mērījumos Kappa ar ļoti labu ticamību ir pozīcijās "simetrisks deguns", "šaura nāsu pamatne", "kolumellas pamatne pārāk plata vai šaura", "saplacināts un hipoplastisks spārns". Savukārt pozīcijas, kuru aprakstîtās deguna deformācijas pazīmes tika konstatētas un atzīmētas visbiežāk, kā "nāsu augšējās malas deformācija" un "plata nāsu pamatne", Kappa rādītāji ir viszemākie, kas norāda par vienprātības trūkumu starp novērtētājiem. 
3.2. tabula

Inter novērtētāja variabilitāte A un B novērtētājam pēc atkārtotiem mērījumiem šķeltnei atrodoties kreisajā (sin) pusē un labajā (dx) pusē

\begin{tabular}{|c|c|c|c|c|c|c|c|c|c|}
\hline \multirow[b]{2}{*}{ Nr. } & \multirow{2}{*}{$\begin{array}{c}\text { Modificētas } \\
\text { Anastassov un } \\
\text { Chipkov (2003) } \\
\text { novērtēšanas skalas } \\
\text { pozīcija }\end{array}$} & \multicolumn{2}{|c|}{$\sin 1$} & \multicolumn{2}{|c|}{$\sin 2$} & \multicolumn{2}{|c|}{$\mathrm{dx} 1$} & \multicolumn{2}{|c|}{$\mathrm{dx} 2$} \\
\hline & & $\%$ & Kappa & $\%$ & Kappa & $\%$ & Kappa & $\%$ & Kappa \\
\hline 1. & Simetrisks deguns & 100 & 1,0 & 100 & 1,0 & 100 & 1,0 & 100 & 1,0 \\
\hline 2. & Kolumella pārāk īsa & 74,4 & 0,2 & 79,1 & NA* & 65,1 & NA & 72,1 & 0,3 \\
\hline 3. & $\begin{array}{l}\text { Redzama starpsienas } \\
\text { subluksācija vai } \\
\text { deviācija }\end{array}$ & 74,4 & 0,2 & 81,4 & 0,4 & 76,7 & NA & 74,4 & NA \\
\hline 4. & Plata nāsu pamatne & 76,7 & 0,5 & 86,1 & 0,7 & 69,8 & 0,3 & 65,1 & NA \\
\hline 5. & Šaura nāsu pamatne & 100 & 1,0 & 100 & 1,0 & 100 & 1,0 & 100 & 1,0 \\
\hline 6. & $\begin{array}{l}\text { Kolumellas pamatne } \\
\text { pārāk plata }\end{array}$ & 93,0 & NA & 100 & 1,0 & 100 & 1,0 & 100 & 1,0 \\
\hline 7. & $\begin{array}{l}\text { Kolumellas pamatne } \\
\text { pārāk šaura }\end{array}$ & 100 & 1,0 & 100 & 1,0 & 100 & 1,0 & 100 & 1,0 \\
\hline 8. & $\begin{array}{l}\text { Nepietiekoša spārna } \\
\text { ieloce }\end{array}$ & 65,1 & 0,2 & 67,4 & NA & 67,4 & NA & 69,8 & NA \\
\hline 9. & $\begin{array}{l}\text { Pārāk izteikta spārna } \\
\text { ieloce }\end{array}$ & 74,4 & 0,1 & 83,7 & 0,1 & 90,7 & 0,1 & 88,4 & 0,1 \\
\hline 10. & $\begin{array}{l}\text { Nāsu augšējās malas } \\
\text { deformācija }\end{array}$ & 69,8 & 0,4 & 65,1 & 0,3 & 64,3 & 0,3 & 64,3 & 0,3 \\
\hline 11. & $\begin{array}{l}\text { Spārna skrimšl̦a } \\
\text { nepareiza pozīcija }\end{array}$ & 79,1 & 0,4 & 74,4 & 0,3 & 79,1 & 0,5 & 81,4 & 0,5 \\
\hline 12. & $\begin{array}{l}\text { Spārna augsta } \\
\text { pozīcija }\end{array}$ & 86,1 & NA & 93,0 & NA & 95,4 & 0,6 & 88,4 & NA \\
\hline 13. & Spārna zema pozīcija & 90,7 & 0,6 & 97,7 & 0,7 & 95,4 & 0,6 & 95,3 & NA \\
\hline 14. & $\begin{array}{l}\text { Saplacināts un } \\
\text { hipoplastisks spārns }\end{array}$ & 100 & 1,0 & 100 & 1,0 & 100 & 1,0 & 100 & 1,0 \\
\hline 15. & Summa & 32,6 & 0,2 & 41,9 & 0,2 & 30,2 & 0,1 & 34,9 & 0,2 \\
\hline
\end{tabular}

*NA - Kappa nav aprēḳināms. Ja Kappa 0,8-1,0 ticamība ḷoti laba, 0,6-0,8 laba, 0,4-0,6 vidēja, 0,2-0,4 slikta, $<0,2$ loti slikta

Vienpusējas caurejošas lūpas, alveolārā izauguma un aukslēju šķeltnes biežāk ir sastopamas kreisajā pusē, šķeltne 20 gadījumos atradās kreisajā pusē, bet 7 gadījumos labajā pusē. Lai noteiktu vai metode ir ticama deguna estētikas noteikšanai neatkarīgi no tā, kurā pusē bērnam ir iedzimta vienpusēja lūpas, alveolārā izauguma un aukslēju šķeltne, tika salīdzināta novērtētāju vienprātība novērtējot viena un tā paša bērna fotoattēlu pāri, kur škseltne atradās kreisajā pusē un pēc tam, spoguḷattēlā, kur škseltne atradās labajā pusē. Kappa koeficienta rezultāti bija līdzīgi kā iepriekš noteiktajās intra un inter novērtētāja variabilitātēs (skat. 3.3. tab.). 
3.3. tabula

Intra novērtētāja variabilitāte A un B novērtētājam pēc atkārtotiem mērījumiem šķeltnei atrodoties kreisajā (sin) pusē un labajā (dx) pusē

\begin{tabular}{|c|c|c|c|c|c|c|c|c|c|}
\hline \multirow[b]{2}{*}{$\mathrm{Nr}$. } & \multirow{2}{*}{$\begin{array}{c}\text { Modificētas } \\
\text { Anastassov un } \\
\text { Chipkov (2003) } \\
\text { novērtēšanas skalas } \\
\text { pozīcija }\end{array}$} & \multicolumn{2}{|c|}{$\mathrm{A} \sin / \mathrm{dx} 1$} & \multicolumn{2}{|c|}{$\mathrm{A} \sin / \mathrm{dx} 2$} & \multicolumn{2}{|c|}{$\mathrm{B} \sin / \mathrm{dx} 1$} & \multicolumn{2}{|c|}{$\mathrm{B} \sin / \mathrm{dx} 2$} \\
\hline & & $\%$ & Kappa & $\%$ & Kappa & $\%$ & Kappa & $\%$ & Kappa \\
\hline 1. & Simetrisks deguns & 100 & 1,0 & 100 & 1,0 & 100 & 1,0 & 100 & 1,0 \\
\hline 2. & Kolumella pārāk īsa & 79,1 & 0,1 & 76,7 & NA* & 83,7 & 0,6 & 93,0 & 0,8 \\
\hline 3. & $\begin{array}{l}\text { Redzama starpsienas } \\
\text { subluksācija vai } \\
\text { deviācija }\end{array}$ & 93,0 & 0,7 & 97,7 & 0,9 & 81,4 & 0,4 & 81,4 & 0,5 \\
\hline 4. & Plata nāsu pamatne & 65,1 & 0,3 & 69,8 & 0,2 & 86,1 & 0,7 & 81,4 & 0,6 \\
\hline 5. & Šaura nāsu pamatne & 100 & 1,0 & 100 & 1,0 & 100 & 1,0 & 100 & 1,0 \\
\hline 6. & $\begin{array}{l}\text { Kolumellas pamatne } \\
\text { pārāk plata }\end{array}$ & 93,0 & NA & 100 & 1,0 & 100 & 1,0 & 100 & 1,0 \\
\hline 7. & $\begin{array}{l}\text { Kolumellas pamatne } \\
\text { pārāk šaura }\end{array}$ & 100 & 1,0 & 100 & 1,0 & 100 & 1,0 & 100 & 1,0 \\
\hline 8. & $\begin{array}{l}\text { Nepietiekoša spārna } \\
\text { ieloce }\end{array}$ & 90,7 & NA & 100 & 1,0 & 83,7 & 0,7 & 93,0 & 0,8 \\
\hline 9. & $\begin{array}{l}\text { Pārāk izteikta spārna } \\
\text { ieloce }\end{array}$ & 90,7 & 0,5 & 90,7 & 0,3 & 93,0 & 0,5 & 95,4 & 0,6 \\
\hline 10. & $\begin{array}{l}\text { Nāsu augšējās malas } \\
\text { deformācija }\end{array}$ & 73,8 & 0,4 & 61,9 & 0,2 & 78,6 & 0,6 & 78,6 & 0,6 \\
\hline 11. & $\begin{array}{l}\text { Spārna skrimšl̦a } \\
\text { nepareiza pozīcija }\end{array}$ & 79,1 & 0,4 & 81,4 & 0,4 & 83,7 & 0,6 & 88,4 & 0,7 \\
\hline 12. & Spārna augsta pozīcija & 90,7 & NA & 88,4 & NA & 90,7 & 0,5 & 93,0 & NA \\
\hline 13. & Spārna zema pozīcija & 88,4 & 0,4 & 97,7 & $\mathrm{NA}$ & 97,7 & 0,8 & 100 & 1,0 \\
\hline 14. & $\begin{array}{l}\text { Saplacināts un } \\
\text { hipoplastisks spārns }\end{array}$ & 100 & 1,0 & 100 & 1,0 & 100 & 1,0 & 100 & 1,0 \\
\hline 15. & Summa & 46,5 & 0,3 & 46,5 & 0,3 & 44,2 & 0,3 & 51,2 & 0,3 \\
\hline
\end{tabular}

*NA - Kappa nav aprēķināms. Ja Kappa 0,8-1,0 ticamība l̦oti laba, 0,6-0,8 laba, 0,4-0,6 vidēja, 0,2-0,4 slikta, $<0,2$ loti slikta

\subsection{Deguna estētikas novērtēšana 2D fotoattēlos ar vizuālo analogu skalu}

Novērtēšana ar VAS izrādījās subjektīva un variabla, gan novērtējot vienam vērtētājam labo un kreiso pusi, gan savstarpēji starp vērtētājiem. Mutes, sejas un žokḷu ķirurgs, kurš operē šķeltnes vidēji bija viszemāk novērtējis deguna estētiku, bet visaugstāk autors. VAS intra novērtētāja atšķirīibas $p$ vērtība visos gadījumos bija $<0,05$, tas nozīmē, ka katru reizi viens un tas pats novērtētājs deguna estētiku bija novērtējis atšksirīgi (skat. 3.1. att.). A un G vērtētājs degunus, kur šķeltne pagriezta uz kreiso pusi novērtēja sliktāk, bet B un F vērtētāji degunus, kur škseltne pagriezta uz labo pusi novērtēja sliktāk. 


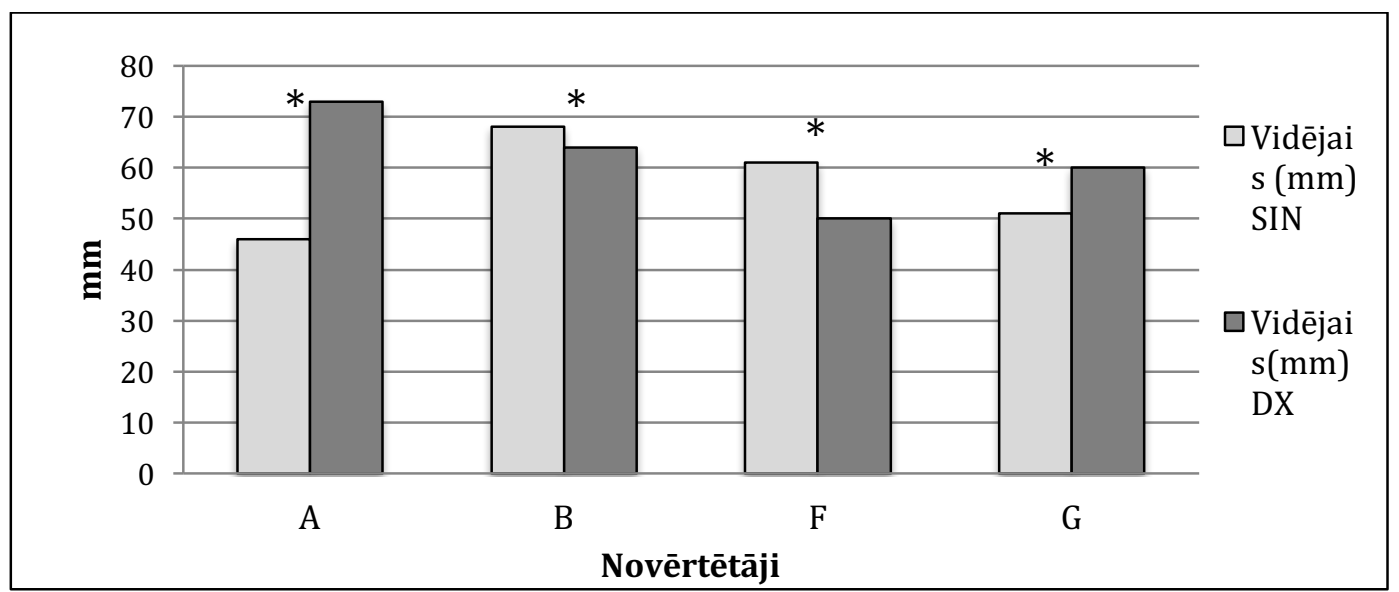

3.1. att. Intra novērtētāju variabilitāte novērtējumam ar VAS šķeltnei atrodoties labajā (dx) un kreisajā (sin) pusē

* statistiski ticama atšķirība, $\mathrm{p}<0,05$

Atšksirība starp novērtētājiem (inter novērtētāja variabilitāte) vērtējot gan kreiso, gan labo pusi bija statistiski ticama $\mathrm{p}<0,05$. Novērtējot deguna estētiku, kur šķeltne atradās kreisajā pusē inter novērtētāju variabilitātei statistiski ticama atšķirība bija starp A un B, A un F, B un G novērtētāja domām par deguna estētiku, bet A un G, B un F, F un G novērtētāju domas bija līdzīgas (skat. 3.4. tab.). Starp visām grupām kopumā, novērtējot deguna estētiku šķeltnei atrodoties kreisajā pusē, inter novērtētāja variabilitāte bija statistiski ticama. Līdzīgi arī šķeltnei atrodoties labajā pusē, inter novērtētāju variabilitāte starp dažiem novērtētājiem statistiski ticami atšks̄īās, bet dažiem domas bija līdzīgas (skat. 3.5. tab.). Starp visām grupām kopumā, novērtējot deguna estētiku šķeltnei atrodoties labajā pusē, inter novērtētāja variabilitāte bija statistiski ticama.

3.4. tabula

Inter novērtētāju variabilitāte šķ̧eltnei atrodoties kreisajā pusē novērtējumam ar VAS

\begin{tabular}{|l|l|l|l|}
\hline Novērtētāji & A & B & F \\
\hline B & $p<0,05$ & & \\
\hline$F$ & $p<0,05$ & $p=0,56$ & \\
\hline$G$ & $p=1,00$ & $p<0,05$ & $p=0,07$ \\
\hline
\end{tabular}

3.5. tabula

Inter novērtētāju variabilitāte šķeltnei atrodoties labajā pusē novērtējumam ar VAS

\begin{tabular}{|l|l|l|l|}
\hline Novērtētāji & A & B & F \\
\hline B & $p=0,06$ & & \\
\hline$F$ & $p<0,05$ & $p<0,05$ & \\
\hline$G$ & $p<0,05$ & $p=1,00$ & $p<0,05$ \\
\hline
\end{tabular}




\subsection{Deguna elpošanas funkcija}

Pētījuma grupas elpošanas plūsmas rādītāju atšķirība pirms un pēc dekongestantu lietošanas nebija statistiski ticama, tāpēc salīdzinājumam tika izmantotas vērtības tikai pēc dekongestācijas. Vidējā deguna elpošanas plūsma bērniem ar vienpusēju caurejošu lūpas, alveolārā izauguma un aukslēju škseltni pēc dekongestanta lietošanas caur veselo nāsi bija $330,6 \mathrm{~cm}^{3} / \mathrm{s}$, caur šķeltnes pusi $169,1 \mathrm{~cm}^{3} / \mathrm{s}$ pie $150 \mathrm{~Pa}$, atšķirība starp veselo nāsi un šķeltnes pusi bija statistiski ticama, $\mathrm{p}<0,05$. Deviņos gadījumos šķ̧eltne bija lokalizēta labajā pusē, bet 21 gadījumā kreisajā pusē. Bērniem, kuriem škseltne bija lokalizēta labajā pusē, bija nedaudz sliktāki elpošanas plūsmas vidējie rādītāji caur šķeltnes pusi, nekā bērniem ar šķeltnes lokalizāciju kreisajā pusē, š̄i atšķirība nebija statistiski ticama. Pētījuma pacientu elpošanas plūsma diapazonā bez obstrukcijas un viegla obstrukcija pēc Bachmann (1983) caur veselo nāsi bija 18 gadījumos, bet caur šķeltnes nāsi 7 gadījumos (skat. 3.2. att.). Vidēja obstrukcija pēc Bachmann tika novērota 6 gadījumos caur veselo nāsi un 9 gadījumos caur šķeltnes nāsi. Smaga obstrukcija tika novērota 6 gadījumos caur veselo nāsi un 14 gadījumos caur šķeltnes nāsi (skat. 3.2.att.). Pacientiem, kuriem primāras lūpas plastikas laikā netika veikta starpsienas repozīija un netika veikta sekundāra deguna korekcija, elpošanas plūsma bija atšķirīga. Pacientam, kurš nebija nācis uz kontrolēm elpošanas plūsma caur šķeltnes pusi bija ar smagu obstrukciju, bet caur veselo pusi bez obstrukcijas, savukārt pacientam, kuram sekundāra deguna korekcija tika atlikta vispārēja veselības stāvokḷa dēḷ, elpošanas plūsma caur šķeltnes pusi bija ar vidēju obstrukcijas pakāpi, bet caur veselo pusi bez obstrukcijas. Pirmais pacients, kuram tika veikta lūpas plastika ar primāru starpsienas repozīciju un bez sekundāras deguna korekcijas, deguna elpošanas plūsma caur šķeltnes pusi bija ar smagu obstrukcijas pakāpi, bet caur veselo pusi ar vieglu obstrukcijas pakāpi, savukārt otrajam pacientam, kuram veikta primāra starpsienas repozīcija elpošanas plūsma caur šķeltnes pusi bija ar vidēju obstrukciju, bet caur veselo pusi ar vieglu obstrukcijas pakāpi.

Četros gadījumos elpošanas plūsma bija sliktāka caur veselo pusi, bet 18 gadījumos sliktāka caur šķeltnes pusi, 8 gadījumos elpošanas plūsma caur abām nāsīm bija vienādā līmenī, no kuriem četros gadījumos elpošanas plūsma caur abām nāsīm bija ar smagu obstrukciju, trīs gadījumos ar vieglu un vienā ar vidēju obstrukcijas pakāpi. Elpošanas plūsmas smaguma pakāpe nebija saistīta ar deguna sekundāras korekcijas laiku vai papildus deguna korekcijām un to skaitu, gan vienā gan otrā gadījumā elpošanas plūsmas smaguma pakāpe bija diapazonā bez obstrukcijas līdz smagai obstrukcijai pēc Bachmann (skat. 3.2. att.). 


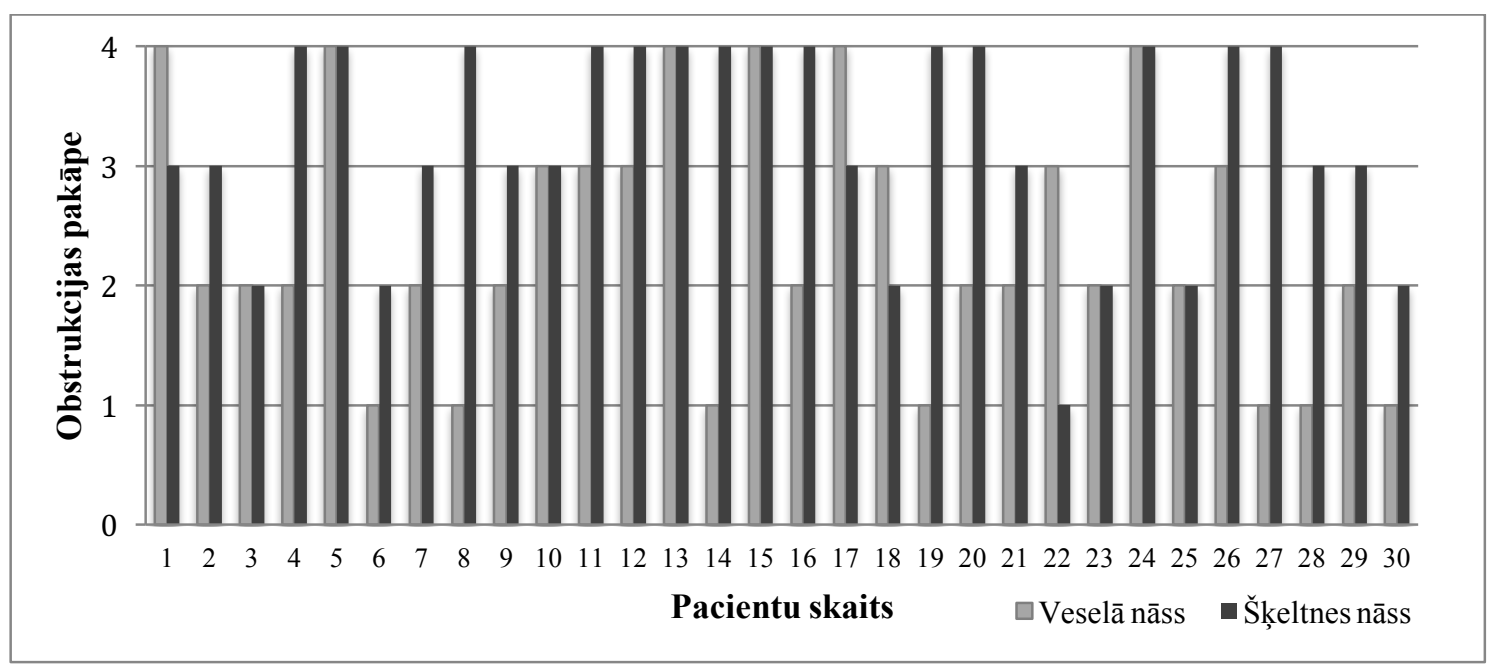

3.2. att. Elpošanas plūsmas obstrukcijas pakāpes pēc Bachmann (1983)

1 - nav obstrukcijas, 2 - viegla obstrukcija, 3 - vidēja obstrukcija, 4 - smaga obstrukcija

Kontroles grupā caur labo pusi elpošana bija $308,4 \mathrm{~cm}^{3} / \mathrm{s}$, caur kreiso pusi $330,4 \mathrm{~cm}^{3} / \mathrm{s}$ pie $150 \mathrm{~Pa}$ pēc dekongestanta lietošanas, š̄ atšķirība nebija statistiski ticama, $\mathrm{p}>0,05$. Kontroles grupā elpošanas plūsmas rādītāju atšksirība pirms un pēc dekongestantu lietošanas bija statistiski ticama gan labajai nāsij, gan kreisajai, $\mathrm{p}<0,05$.

Atšķirība starp deguna elpošanu caur šķeltnes pusi pacientiem ar vienpusēju caurejošu lūpas, alveolārā izauguma un aukslēju škseltni un starp kontroles grupas labo vai kreiso pusi bija statistiski ticama $\mathrm{p}<0,05$ pēc dekongestanta lietošanas (skat. 3.3. att.). Bet salīdzinot elpošanas plūsmu caur veselo nāsi pētîjuma grupā un kontroles grupas labo vai kreiso nāsi, statistiski ticamas atšķirības nebija. Akustiskās rinomanometrijas dati uzrāda statistiski ticamas atšķirības starp šķeltnes pusi un veselo pusi, kā arī salīdzinājumā ar kontroles grupu.

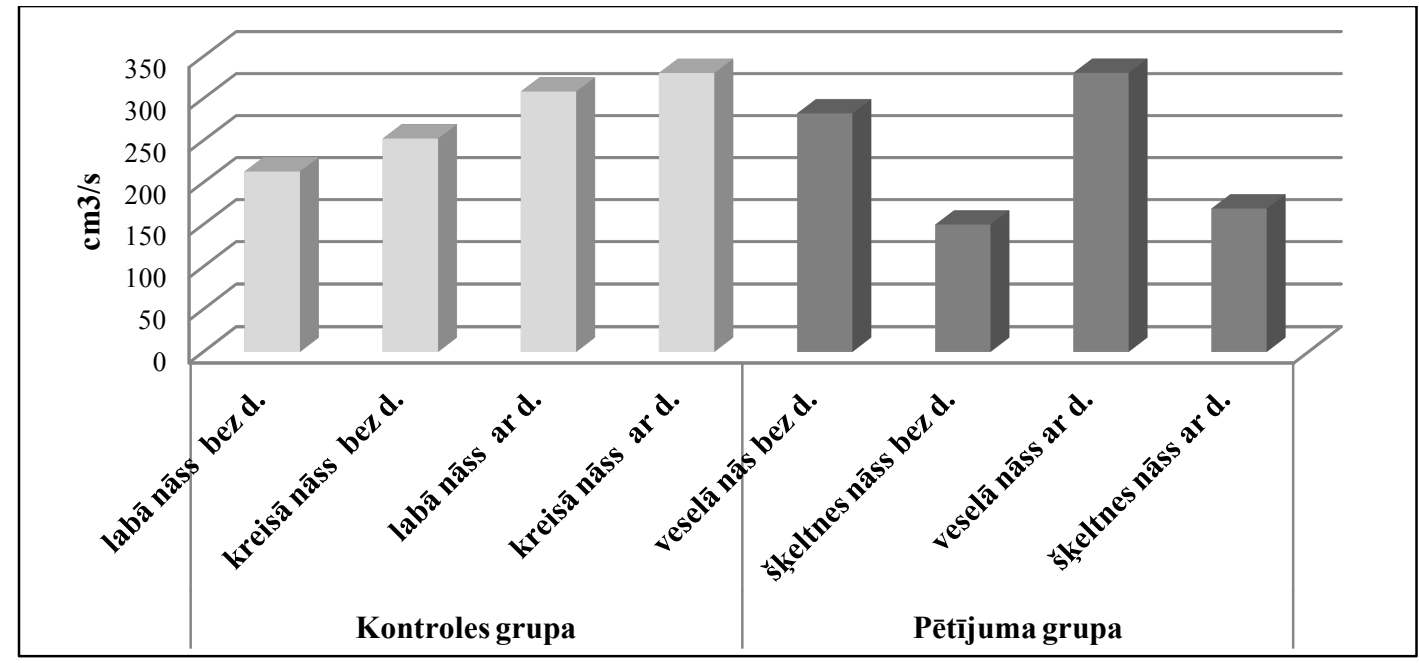

3.3. att. Vidējie elpošanas plūsmas rādītāji pētījuma un kontroles grupā pie 150 Pa d. - dekongestants (Xymelin 0,1\%) 


\subsection{Deguna un augšlūpas simetrija 3D fotoattēlos}

Mērījumu kḷūda starp pirmo un otro mērījumu reizi 3D fotoattēlos nepārsniedza 3\% no kopējās dispersijas. Tā kā statistiski ticama atšķirība netika pierādīta starp pirmo un otro mērījumu reizi (intra novērtētāja variabilitāte) ne pētījuma grupā, ne kontroles grupā, tad tālākai mērījumu salīdzināšanai tika izmantota pirmā un otrā mērījuma vidējā vērtība. Pētījuma grupā vienīgais mērījums ar statistiski ticamu atšķirību starp šķeltnes un ne šķeltnes pusi bija deguna spārna garums (al-PRN), kurš bija īsāks un vairāk saplacināts šķeltnes pusē $(p<0,05)$ (skat. 3.4. att.).

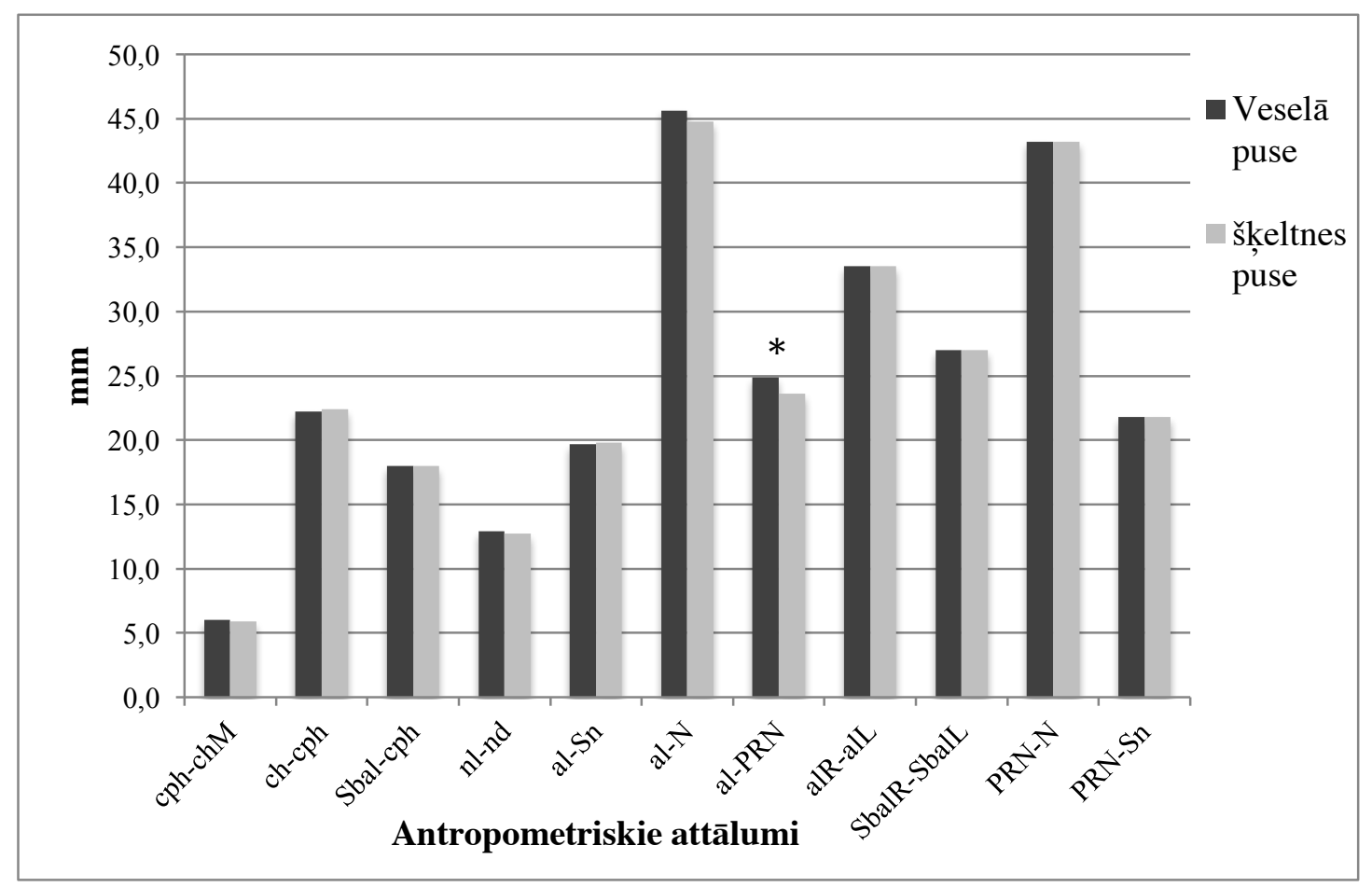

\section{4. att. Antropometriskie attālumi pētījuma grupā \\ * Statistiski ticama atšķirība, $\mathrm{p}<0,05$}

Atšķirības kontroles grupā starp labo un kreiso deguna pusi nebija statistiski ticamas. Atšķirības starp pētījuma un kontroles grupu bija statistiski ticamas visos mērījumu parametros izṇemot lūpas garums līdz lūpas lociņam abās pusēs (chR-cphR, chL-cphL) (skat. 3.5. att.). Apmierinoša deguna un lūpas simetrija tika sasniegta visiem pacientiem. 


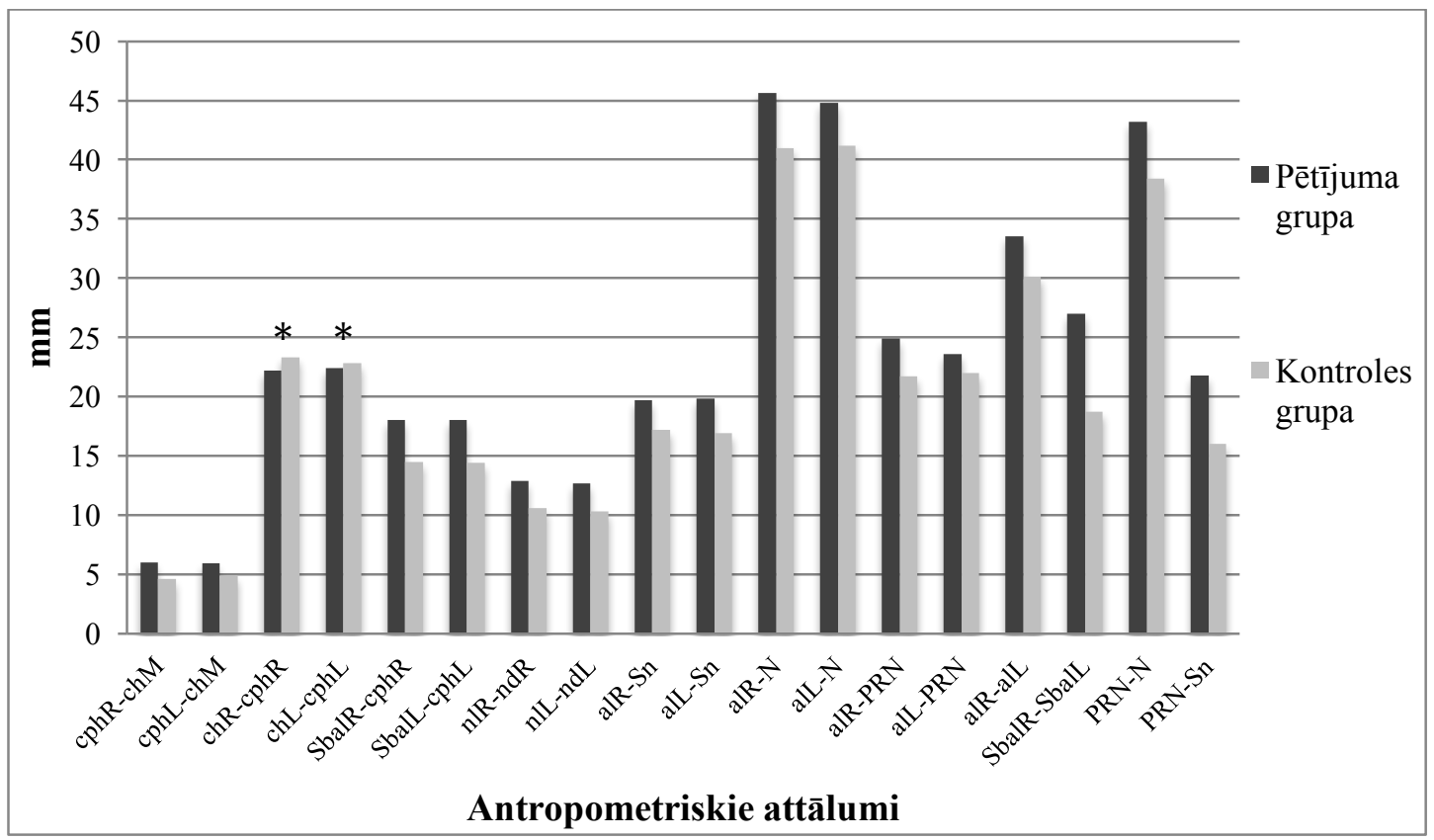

3.5. att. Antropometriskie attālumi milimetros starp pacientiem ar vienpusēju caurejošu lūpas, alveolārā izauguma un aukslēju šķeltni (pētījuma grupa) un kontroles grupu

* Nav statistiski ticama atšksirība, p >0,05

Pētījuma grupā simetrijas indeksa atšķirība starp šķeltnes un veselo pusi attiecībā pret 100 (ideāla simetrija) statistiski ticama atšksirība bija starp lūpas loka attālumiem līdz viduslīnijai (cph-cM), deguna garumu sānu pusē (al-N) un deguna spārna garumu (al-PRN) šķeltnes un veselajā pusē. Starp pārējiem mērījumiem statistiski ticamas atšķirības nebija (skat. 3.6. tab.).

3.6. tabula

Pētījuma grupā simetrijas indeksa atšķirība starp šķeltnes un veselo pusi

\begin{tabular}{|l|l|l|c|c|}
\hline Nr. & \multicolumn{1}{|c|}{ Simetrijas indekss } & \multicolumn{1}{|c|}{ Apraksts } & $\begin{array}{c}\text { Simetrijas indeksa } \\
\text { vidējā vêrtība (SD) }\end{array}$ & $\begin{array}{c}\text { Paired } \text { tests } \\
(\mathrm{p}<0,05)\end{array}$ \\
\hline 1 & $\frac{\mathrm{cphL}-\mathrm{chM}}{\mathrm{cphR}-\mathrm{chM}} \times 100$ & $\begin{array}{l}\text { Lūpas loka attālums līidz } \\
\text { viduslīnijai }\end{array}$ & $110(25,9)$ & $\mathrm{p}=0,04$ \\
\hline 2 & $\frac{\mathrm{chL}-\mathrm{cphL}}{\mathrm{chR}-\mathrm{cphR}} \times 100$ & $\begin{array}{l}\text { Lūpas garums līdz lūpu } \\
\text { lokam }\end{array}$ & $100(10,5)$ & $\mathrm{p}=0,92$ \\
\hline 3 & $\frac{\mathrm{SbalL}-\mathrm{cphL}}{\mathrm{SbalR}-\mathrm{cphR}} \times 100$ & Baltās lūpas garums & $97(13,5)$ & $\mathrm{p}=0,23$ \\
\hline 4 & $\frac{\mathrm{nlL}-\mathrm{ndL}}{\mathrm{nlR}-\mathrm{ndR}} \times 100$ & Nāsu augstums & $98(12,5)$ & $\mathrm{p}=0,28$ \\
\hline 5 & $\frac{\mathrm{alL}-\mathrm{Sn}}{\mathrm{alR}-\mathrm{Sn}} \times 100$ & Nāsu platums pie pamatnes & $100(10,0)$ & $\mathrm{p}=0,88$ \\
\hline 6 & $\frac{\mathrm{alL}-\mathrm{N}}{\mathrm{alR}-\mathrm{N}} \times 100$ & Deguna sāna garums & $98(3,8)$ & $\mathrm{p}=0,01$ \\
\hline 7 & $\frac{\mathrm{alL}-\mathrm{PRN}}{\mathrm{alR}-\mathrm{PRN}} \times 100$ & Deguna spārna garums & $95(11,4)$ & $\mathrm{p}=0,02$ \\
\hline
\end{tabular}


Kontroles grupā simetrijas indeksa statistiski ticama atšķirība starp labo un kreiso pusi attiecībā pret 100 bija nāsu augstumam (nl-nd) (skat. 3.7. tab.).

3.7. tabula

Kontroles grupā simetrijas indeksa atšķirība starp kreiso un labo pusi

\begin{tabular}{|l|l|l|c|c|}
\hline Nr. & \multicolumn{1}{|c|}{ Simetrijas indekss } & \multicolumn{1}{|c|}{ Apraksts } & $\begin{array}{c}\text { Simetrijas indeksa } \\
\text { vidējā vērtība (SD) }\end{array}$ & $\begin{array}{c}\text { Paired } \mathrm{t} \text { tests } \\
(\mathrm{p}<0,05)\end{array}$ \\
\hline 1 & $\frac{\mathrm{cphL}-\mathrm{chM}}{\mathrm{cphR}-\mathrm{chM}} \times 100$ & $\begin{array}{l}\text { Lūpas loka attālums līdz } \\
\text { viduslīnijai }\end{array}$ & $103(29,2)$ & $\mathrm{p}=0,54$ \\
\hline 2 & $\frac{\mathrm{chL}-\mathrm{cphL}}{\mathrm{chR}-\mathrm{cphR}} \times 100$ & $\begin{array}{l}\text { Lūpas garums līdz lūpu } \\
\text { lokam }\end{array}$ & $98(7,5)$ & $\mathrm{p}=0,14$ \\
\hline 3 & $\frac{\mathrm{SbalL}-\mathrm{cphL}}{\mathrm{SbalR}-\mathrm{cphR}} \times 100$ & Baltās lūpas garums & $102(8,1)$ & $\mathrm{p}=0,13$ \\
\hline 4 & $\frac{\mathrm{nlL}-\mathrm{ndL}}{\mathrm{nlR}-\mathrm{ndR}} \times 100$ & Nāsu augstums & $96(10,2)$ & $\mathrm{p}=0,03$ \\
\hline 5 & $\frac{\mathrm{alL}-\mathrm{Sn}}{\mathrm{alR}-\mathrm{Sn}} \times 100$ & Nāsu platums pie pamatnes & $100(12,8)$ & $\mathrm{p}=0,85$ \\
\hline 6 & $\frac{\mathrm{alL}-\mathrm{N}}{\mathrm{alR}-\mathrm{N}} \times 100$ & Deguna sāna garums & $101(3,2)$ & $\mathrm{p}=0,34$ \\
\hline 7 & $\frac{\mathrm{alL}-\mathrm{PRN}}{\mathrm{alR}-\mathrm{PRN}} \times 100$ & Deguna spārna garums & $102(6,8)$ & $\mathrm{p}=0,19$ \\
\hline
\end{tabular}

Salīdzinot simetrijas indeksus starp pētîjuma grupu un kontroles grupu, statistiski ticama atšķirība tika novērota starp baltās lūpas garumu (Sbal-cph), deguna garumu sānu pusē (al-N) un deguna spārna garumu (al-PRN) (skat. 3.8. tab.).

3.8. tabula

Pētījuma un kontroles grupas simetrijas indeksa atšķirības

\begin{tabular}{|c|c|c|c|}
\hline Nr. & Simetrijas indekss & Apraksts & Unpaired $\mathrm{t}$ tests $(\mathrm{p}<0,05)$ \\
\hline 1 & $\frac{\operatorname{cphL}-\operatorname{chM}}{\operatorname{cphR}-\operatorname{chM}} \times 100$ & $\begin{array}{l}\text { Lūpas loka attālums līdz } \\
\text { viduslīnijai }\end{array}$ & $\mathrm{p}=0,15$ \\
\hline 2 & $\frac{\operatorname{chL}-\operatorname{cphL}}{\operatorname{chR}-\operatorname{cphR}} \times 100$ & $\begin{array}{l}\text { Lūpas garums līdz lūpu } \\
\text { lokam }\end{array}$ & $\mathrm{p}=0,22$ \\
\hline 3 & $\frac{\text { SbalL }-\mathrm{cphL}}{\text { SbalR }-\mathrm{cphR}} \times 100$ & Baltās lūpas garums & $\mathrm{p}=0,03$ \\
\hline 4 & $\frac{\mathrm{nlL}-\mathrm{ndL}}{\mathrm{nlR}-\mathrm{ndR}} \times 100$ & Nāsu augstums & $\mathrm{p}=0,29$ \\
\hline 5 & $\frac{\mathrm{al} L-\mathrm{Sn}}{\mathrm{alR}-\mathrm{Sn}} \times 100$ & Nāsu platums pie pamatnes & $\mathrm{p}=0,48$ \\
\hline 6 & $\frac{\operatorname{all}-N}{\operatorname{alR}-N} \times 100$ & Deguna sāna garums & $\mathrm{p}=0,003$ \\
\hline 7 & $\frac{\mathrm{al} L-\mathrm{PRN}}{\mathrm{alR}-\mathrm{PRN}} \times 100$ & Deguna spārna garums & $\mathrm{p}=0,002$ \\
\hline
\end{tabular}


Novērtējot ķirurğijas rezultātu pēc $L i$ ar kolēgiem (2010), pētījumā iesaistītajiem pacientiem ar vienpusēju caurejošu lūpas, alveolārā izauguma un aukslēju šķeltni tika sasniegts labs pēc operācijas rezultāts, jo vidējais simetrijas indekss bija robežās no 95-110\%. Ja estētikas indekss degunam un lūpai ir robežās no 90-110\%, tad tiek uzskatīts, ka ķirurǵijas rezultāts ir izdevies (Li et al., 2010).

Tika noteikta saistība starp elpošanas funkciju un deguna estētiku pacientu grupā ar vienpusēju caurejošu lūpas, alveolārā izauguma un aukslēju šķeltni, statistiski ticama saistība netika pieradīta. Bet elpošanas funkcija caur veselo nāsi bija atkarīga no kopējā deguna platuma (alR-alL) $(\mathrm{p}=0,04)$, jo platāks bija deguns, jo sliktāka bija elpošana, bet elpošanas funkciju caur šķeltnes pusi deguna platums neietekmēja. Savukārt elpošanas plūsmai caur šķeltnes pusi bija statistiski ticama saistība ar deguna muguriņas garumu $(P R N-N)(p=0,04)$. Jo garāka bija deguna muguriņa, jo elpošana bija labāka caur šķeltnes pusi, bet elpošanas plūsmu caur veselo nāsi tas neietekmēja. 


\section{DISKUSIJA}

\subsection{Pētījuma kopa}

Lūpu un aukslēju šķeltnes ir biežākā iedzimtā patologiija sejas un žokḷu rajonā. Iedzimti sejas šķeltņu veidi un smaguma pakāpes ir ļoti variablas. Šķeltnes var būt gan vienpusējas, gan divpusējas, tās var būt daļējas vai caurejošas. Tāpat arī to platums un deformācijas smaguma pakāpe ir ļoti individuāla. Pacientus ar vienpusēju caurejošu lūpas, alveolārā izauguma un aukslēju šķeltni visplašāk izmanto pētījumos, jo pareizas diagnozes gadījumā ir apmēram vienāda deformācija, protams, šķeltnes platums var būt atšķirīgs. Tāpēc, lai varētu novērtēt ķirurgískās ārstēšanas rezultātus pēc iespējas objektīvāk, tika nolemts abās pētījuma daḷās iekḷaut tikai vienpusējas caurejošas lūpas, alveolārā izauguma un aukslēju šķeltnes, pie kurām vienmēr novēro tipisku deguna deformāciju. Šo šķeltņu ķirurǵgiskā ārstēšana ir sarežğīta un grūti panākt gan labu estētisku gan funkcionālu rezultātu. Tā kā šķeltne ir vienpusēja, novēro izteiktu deguna un augšlūpas asimetriju.

Pirmajā pētījuma daḷā, deguna estētikas novērtēšanai divdimensiju fotoattēlos tika iekḷauti 27 bērni, tomēr vairāku bērnu 2D fotoattēli 3 vai 5 gadu vecumā bija sliktā kvalitātē vai neprecīzā projekcijā un deguna estētikas novērtēšanai nebija derīgi. Statistiski apstrādājot datus, saskarāmies ar grūtībām tos interpretēt mazo grupu dēḷ. Sākotnēji pētījuma pirmās daļas mērķis, bija salīdzināt deguna estētikas rezultātus bērniem, kuriem veikta tikai primāra lūpas un deguna korekcija ar bērniem, kuriem papildus veikta deguna starpsienas skrimšḷainās daļas repozīcija primāras lūpas un deguna korekcijas laikā. Tā kā deguna estētikas novērtēšanas metode 2D fotoattēlos uzrādīja variablus ticamības rezultātus, tad salīdzināt grupas nebija iespējams, jo rezultāti nebūtu ticami. N̦emot vērā arī to, ka sadalot pētījuma grupu divās dạ̦ās, pacientu skaits katrā grupā būtu vēl mazāks. Tā kā šì pētījuma sadaḷa bija retrospektīva, tad pacientu skaitu nebija iespējams palielināt, jo pētījumā tika iekḷauti visi pacienti ar vienpusēju caurejošu lūpas, alveolārā izauguma un aukslēju šķeltni, kuri ārstējušies RSU SI Lūpu, aukslēju un sejas šķeltņu centrā šajā laika posmā un kuriem bija pieejami kvalitatīvi 2D fotoattēli. Pirms 1995. gada operētiem bērniem divdimensiju fotoattēli nebija pieejami, nebija atbilstošajā vecumā, bija neprecīzā projekcijā vai sliktā kvalitātē.

Otrajā pētîjuma daļā tika iekḷauti 35 bērni ar iedzimtu nesindromisku vienpusēju caurejošu lūpas, alveolārā izauguma un aukslēju šķeltni vecumā no 10 līdz 18 gadiem, no kuriem 30 (86\% atsaucība) atnāca uz kontroli un tika izmeklēti pēc pētījuma protokola. Visu škseltņu veidu dzimstības biežums Latvijā ir aptuveni 1,2-1,4 uz 1000 dzīvi dzimušiem bērniem katru gadu, no kuriem tikai 36\% ir lūpu un aukslēju šķeltnes (Akota u.c., 2001). Savukārt 
vienpusējas caurejošas lūpas, alveolārā izauguma un aukslēju šķeltnes biežums ir vēl mazāks, tāpēc, lai varētu nodrošināt pietiekoši lielu pētījuma grupu, tika izvēlēts pacientu vecuma diapazons no 10-18 gadiem. Bell ar kolēǵiem (2014) norāda, ka desmit gadi ir labs robežvecums, kad ir jānovērtē bērna sejas asimetrijas apjoms, kas var ietekmēt tālāko ārstēšanas plānu. Ar desmit gadus veciem bērniem ir iespējama laba komunikācija un sadarbība dažādiem izmeklējumiem, kā 3D stereo-fotogrammetrija un aktīva priekšēja rinomanometrija. Tas ir svarīgi, lai izmeklējumi būtu kvalitatīivi un kvantitatīvi. Savā darbā nesaskarāmies ar grūtībām bērniem veikt kvalitatīvus priekšējas rinomanometrijas vai 3D foto izmeklējumus. Augšèjā vecuma robeža 18 gadi tika izvēlēta divu iemeslu dēḷ, pirmkārt, līdz 18 gadiem bērniem tiek pabeigtas šķelţ̦u deformāciju korekcijas ar ikgadēju kontroli RSU SI Lūpu, aukslēju un sejas šķelţ̦u centrā. Otrs iemesls, lai būtu iespējams nodrošināt pietiekoši lielu pētījuma grupu un dati varētu tikt statistiski apstrādāti ar ticamiem rezultātiem. Divdimensiju fotoattēlu novērtēšanas sadạ̦ā iekḷautie bērni lielākā daļa bija tie paši, kuri iekḷauti novērtēšanai 3D fotoattēlos. Tā kā dzimušie bērni pēc 2004. gada nebija sasnieguši 10 gadu vecumu, tad tos nevarēja iekḷaut 3D pētījumā, bet, lai palielinātu grupu, tika iekḷauti 1994. gadā dzimušie bērni. Kā redzams pētījumā, desmit gadu laikā no 1994.-2004. gadam Latvijā piedzimuši tikai 35 bērni ar vienpusēju caurejošu lūpas, alveolārā izauguma un aukslēju šķeltni no kuriem 10 bērni dzimuši 1994. gadā, savukārt tikai pa vienam bērnam ar vienpusēju caurejošu lūpas, alveolārā izauguma un aukslēju šķeltni bija piedzimuši 2002. un 2004. gadā. Mercado ar kolēgiem (2011) norāda, ka optimāls pacientu skaits multicentru pētîjumam būtu nepieciešams vismaz 30-40 dalībnieku no katra centra. Savukārt Bugaighis ar kolēǵiem (2014) norāda, ka pat Lielbritānijā veiktajā pētījumā bija nepieciešams paplašināt iekḷauto pacientu vecuma diapazonu līdz pieciem gadiem, lai varētu nodrošināt pietiekoši lielu pētījuma grupu, kas ir ierasta parādība pētījumos pacientiem ar dažādām iedzimtām šķeltnēm (Bugaighis et al., 2014a; Bugaighis et al., 2014b).

Kontroles grupā iekļauti 35 bērni 10 gadu vecumā. Desmit gadu vecums tika izraudzīts, jo tā ir apakšējā robeža bērnu vecumam pētījuma grupā, kā arī 2014. gadā RSU Stomatoloǵijas Institūtā tika uzsākts starptautisks sejas augšanas novērtēšanas pētījums, kuram tika nejauši atlasīti veseli bērni 10 gadu vecumā. Bija iespējams no šī pētījuma iesaistīt pirmos 35 bērnus kā kontroles grupu. Kontroles grupas atlases lielums tika pielīdzināts pētîjuma grupas atlases lielumam - 35 bērni, lai abas grupas būtu viendabīgas. Kontroles grupu ar veseliem bērniem ir sarežḡīti atrast gan no sociālā, gan no ètiskā viedokḷa, bet īpaši, ja jāveic kādi izmeklējumi, kuriem nepieciešama aktīva bērna līdzdalība, piemēram, aktīva priekšēja rinomanometrija. Literatūras izpētē par deguna estētikas novērtēšanas metodēm, no 143 atlasītajiem rakstiem, tikai 23 rakstos kā kontroles grupa tika izmantoti veseli bērni dažādos vecumos. Piemēram, 
Miyamoto un Nakajima (2010) kontroles grupai izmantoja 15 veselus bērnus vecumā no 5-8 gadiem, kuriem bija pieejami $C T$ dati pēc sejas traumām, kurās nebija iesaistīts deguns. Trotman ar kolēǵiem (2007) kontroles grupā izmantoja 37 veselus indivīdus vecumā no 5-21 gadam, kuriem tika veikta video ierakstǐšana. Rakstos, kuros kontroles grupai tika izmantoti bērni, pārsvarā tika veikti 2D foto (McComb \& Coghlan, 1996; Kyrkanides et al., 1996; Kim et al., 2004; Daelemans et al., 2006; Russell et al., 2009; Meazzini et al., 2010; Fudalej et al., 2012; Russell et al., 2014) vai 3D foto (Duffy et al., 2000; Hood et al., 2003; Hood et al., 2004; Ayoub et al., 2011; Zreaqat et al., 2012; Bell et al., 2014; Bugaighis et al., 2014a; Bugaighis et al., 2014b; Dadáková et al., 2016; Wu et al., 2016a,b), vienā gadījumā tika veikts video ieraksts (Trotman et al., 2007), vienā gadījumā sejas gipša veiduḷi (Russell et al., 2000), vienā gadījumā klīniska izmeklēšana (Oosterkamp et al., 2007) un divos gadījumos jau esoši CT dati pēc sejas traumām (Miyamoto \& Nakajima, 2010; Miyamoto et al., 2012).

Šajā pētījumā izmantotā kontroles grupa bija unikāla ar to, ka bērniem tika veikti ne tikai 3D foto, bet arī deguna funkcijas novērtējums ar priekšēju rinomanometriju.

\section{2. Ķirurğiskāāārstēšana}

Pēdējo divu gadu desmitu laikā, ievērojamu uzmanību ir saņēmusi primāra deguna korekcija primāras lūpas plastikas laikā. Torre ar kolẹgiem (2000) uzskata, ka agrīna deguna korekcija nodrošina simetriskāku deguna skrimšļu augšanu (Torre et al., 2000). Arī Byrd un Salomon (2000) uzskata, ka primāra deguna korekcija pacientiem ar šķeltnes izraisītu deguna deformāciju rada simetriskāku degunu un labāku vispārējo izskatu agrīnā dzīves periodā, kas ievērojami samazina psiholoǵisko traumu agrīnos skolas gados. Kā arī, kad būs nepieciešama galīgā deguna korekcija pēc augšanas perioda beigām, deguna deformācija būs mazāk smaga un iespējams sasniegt labāku beigu rezultātu (Byrd \& Salomon, 2000). Guyuron (2008) uzsver, kaut arī agrīna ķirurğija samazina psiholoǵiskās problēmas, tā neizslēdz iespējamu deguna deformāciju nākotnē un nepieciešamību pēc papildus deguna korekcijām (Guyuron, 2008). McComb pirmais publicēja primāras deguna rekonstrukcijas tehniku 1975. gadā ar sekojošu ilgtermiṇa pētījumu, kuru publicēja 1996. gadā ar līdzautoru (McComb \& Coghlan, 1996). Tika sasniegti ilgtermiņā stabili rezultāti, bez atgriezeniskas nāsu loka noslīdēšanas un deguna augšana nebija traucēta (Chowchuen et al., 2010a). Šobrīd liela daļa deguna deformācijas tiek korig̣ētas primāras lūpas plastikas laikā. Arī RSU SI Lūpu, aukslēju un sejas šķeltņu centrā, pēdējo desmitu gadu laikā liela uzmanība tikusi pievērsta deguna starpsienas skrimšļainās daļas korekcijai primāras lūpas un deguna plastikas laikā. Mēs esam ievērojuši, ka pēc starpsienas novietošanas pareizā pozīcijā lūpas plastikas laikā, deguns aug simetriskāks un nav bijusi 
nepieciešama sekundāra deguna korekcija pirmsskolas vecumā. Kā redzams pētījuma rezultātos, pagaidām tie ir tikai divi gadījumi, kuri ir sasnieguši desmit gadu vecumu un kuriem nav bijusi sekundāra deguna korekcija pirmsskolas vecumā. Nepieciešami daudzi gadi un lielāks pacientu skaits, lai pierādītu, ka agrīna starpsienas repozīcija izraisa simetriskāku deguna augšanu un iespējams mazāku operāciju skaitu atbilstoša rezultāta sasniegšanai.

Mūsdienu sabiedrībā arvien lielāka uzman̄̄ba tiek pievērsta cilvēka izskatam un estētikai. Ievērojama deguna deformācija var izraisīt psiholoǵiskas problēmas jau agrā bērnībā. Skola daudziem bērniem ir pirmā iestāde, kur satiekas ar citiem bērniem un sākas socializēšanās process. Izsmiešana un ķircināšana ir ierasta parādība īpaši bērniem ar iedzimtām sejas škseltnēm (Lorot-Marchand et al., 2015). Gosain un Fathi (2009) uzskata, ka sekundāra deguna korekcija pie vienpusējas caurejošas lūpas, alveolārā izauguma un aukslēju šķeltnes bieži ir indicēta bērniem pirmsskolas vecumā (6-8 gadi). Šajā vecumā ievērojami pieaug pacientu sociālā saskarsme un viņi sāk sajust ievērojamu spiedienu no vienaudžiem, kas veido šo bērnu pašapziņu. Kaut arī galējā rinoplastika joprojām būs nepieciešama pēc deguna augšanas beigām, autori uzskata, ka sekundāra deguna korekcija pirmsskolas vai agrīnā skolas vecumā iespējams garantē optimālu bērna attīstības pašapziņu (Gosain \& Fathi, 2009). RSU SI Lūpu, aukslēju un sejas šķeltņu centrā pacientiem ar vienpusēju caurejošu lūpas, alveolārā izauguma un aukslēju šķeltni pie ievērojamas deguna deformācijas tiek veikta sekundāra deguna korekcija jau pirmsskolas vai agrīnā skolas vecumā (6-10 gadi).

\subsection{Deguna estētikas un funkcijas novērtēšanas metodes}

Estētika nav vienkārši novērtējama ar objektīviem mērījumiem (Russell et al., 2009). Sejas formas novērtēšanas metodes varētu iedalīt divās grupās - objektīvās metodes, kur tiek lietoti mērījumi un subjektīvās novērtēšanas metodes, kur tiek lietotas vērtēšanas sistēmas, kas pamatojas no sejas apskates secinājumiem un dažiem papildus punktiem (Yamada et al., 1999). Tā kā deguna estētikas novērtēšana 2D fotoattēlos joprojām rakstos ir visbiežāk aprakstītā metode, ir plaši pieejama, ekonomiski izdevīga un ar lielu datubāzi, tā tika izmantota arī šajā darbā. Kopš Eurocleft 1996-2000 publicētā projekta, 2D fotografěšana ir noteikta kā standartprocedūra datu uzkrāšanai, lai vēlāk būtu iespējama datu salīdzināšana starp Eiropas šķeltņu centriem (Shaw et al., 2001). Tika nolemts veikt retrospektīvu deguna estētikas noteikšanu 2D fotoattēlos. Deguna estētikas novērtēšana 2D fotoattēlos izrādījās laikietilpīga, jo bija nepieciešama iepriekšēja materiāla sagatavošana un novērtētāju sagatavošana, lai nodrošinātu maksimāli standartizētus apstākḷus vairākas nedēḷas pēc kārtas. Līdz ar to pētījuma laikā bija nepieciešams piesaistīt vairākus pêtījuma dalībniekus, kuri piedalījās fotoattēlu 
anonīmā sajaukšanā un novērtěšanā, lai būtu iespējama inter novērtētāja variabilitātes noteikšana. Deguna estētikas novērtējums pie škseltnēm ir komplicēts, tāpēc 2D fotoattēlos tika iekl̦autas divas novērtēšanas metodes - ar pielāgoto un modificēto Anastassov un Chipkov (2003) izstrādāto detalizēto vērtēšanas skalu un ar vizuālo analogu skalu (VAS). Anastassov un Chipkov (2003) izstrādātā klīniska vērtēšanas skala pielāgota deguna estētikas novērtēšanai 2D fotoattēlos. Šāda pielāgota Anastassov un Chipkov (2003) shēma tika izmantota arī Baltic Cleft Network multicentru pētījumā, kur papildus tika novērtēta arī lūpas estētika un lūpas muskuļu funkcija. Baltic Cleft Network multicentru pētījuma rezultāti vēl nav zināmi. Pētījuma pirmajā daļā saskarāmies ar nekvalitatīvām 2D fotogrāfijām, kuras bija neprecīzā projekcijā, izplūdušas, vai nebija pieejamas. Arī Mercado ar kolēgiem (2011) veicot multicentru pētījumu, konstatēja, ka nevienā centrā veicot divdimensiju fotografěšanu nelieto galvas stabilizētāju, lai standartizētu galvas pozīciju fotoattēla uzņemšanas laikā. Līdz ar to nevar objektīvi salīdzināt ķirurgíijas rezultātus starp vairākiem centriem. Daudzos centros netiek veiktas fotogrāfijas kolumellas projekcijā, kas ir ļoti svarīga deguna estētikas novērtēšanai (Mercado et al., 2011).

Diskusijas par deguna estētikas novērtēšanas metodēm pacientiem ar lūpu un aukslēju šķeltnēm joprojām ir aktuālas. Literatūrā atrodamas daudz un dažādas novērtēšanas metodes, kas norāda, ka neviena nav nevainojama. Vairākos pētījumos deguna estētiskajai novērtēšanai tika lietotas vairākas mērījumu sistēmas un metodes vienlaicīgi. Literatūras analīzē, ko veica Al-Omari ar kolēǵiem (2005) tika secināts, ka nav atrasta neviena nevainojama metode ar kuru varētu novērtēt deguna estētiku. Tomēr kā viena no daudzsološākajām metodēm deguna estētikas novērtēšanai tika atzīti trīsdimensiju fotoattēli (Al-Omari et al., 2005). Pēdējo gadu tendences deguna estētikas novērtēšanā ir sejas lāzerskenēšana ar trīsdimensionālu datorizētu anatomisko punktu un leņķu novērtēšanu, kas ir objektīvāka un pieḷauj izmantot mazāku pētījuma grupu. Trīsdimensionāla simetrijas analīze tika izmantota gan uz 28 pacientu deguna gipša veiduļiem, kuri tika ieskenēti ar elektromagnētisku skenēšanas ierīci un pēc tam datorizēti apstrādāti un veikti mērījumi (Russell et al., 2011). Gan uz 3D fotoattēliem, kuri tika fotografēti ar 3D vision capture tehniku un salīdzināta 21 cilvēka ar vienpusēju caurejošu lūpas, alveolārā izauguma un aukslēju šķeltni grupa ar 96 veselu cilvēku kontroles grupu (Ayoub et al., 2011). Daudzi autori norādīja, ka tālāka 3D analīze ar vairāk pacientiem ļaus veikt plašāku un sistemātiskāku analīzi, novērtējot ķirurğiskās tehnikas rezultātus, lai varētu uzlabot sejas simetriju (Stauber et al., 2008). Savukārt Mori ar kolēgiem (2005) izmantoja bezkontakta semikonduktora lāzera 3D mērījumu sistēmu. Savā darbā autori norādīja, ka šī metode bija daudz ticamāka, lai novērtētu deguna ķirurğiskos rezultātus pacientiem ar škseltnēm (Mori et al., 2005). Arī Devlin ar kolēg̣iem (2007) norādīja, ka 3D stereo-fotogrammetrija bija neinvazīva, precīza un labi arhivējama metode, lai novērtētu sejas formu un ķirurǵiskās 
pārmaiņas. Deguna simetriju varēja kvantitatīvi un precīzi izmērīt ar šo ierīci (Devlin et al., 2007). Tomēr jāatzīmē, ka šīs metodes izmantošana ir tehnologiiski dārgāka un atsevišksos reǵionos nav pieejama (Russell et al., 2011). N̦emot vērā jaunās tehnoloǵijas plusus, pieejamību un pieredzi deguna estētikas novērtēšanā $2 \mathrm{D}$ fotoattēlos, pêtījuma otrajā dạ̧ā tika nolemts izmantot 3D stereo-fotometrisku izmeklējumu sejas virsmas topogrāfiskas anatomijas un krāsu tekstūras iegūšanai, lai novērtētu deguna un augšlūpas simetriju bērniem ar vienpusēju caurejošu lūpas, alveolārā izauguma un aukslēju šķeltni. Šĩ iekārta ir vienkārša, ērti lietojama, pacientiem draudzīga, ne invazìva, ātra un var tikt lietota bērniem.

Literatūrā nav arī vienprātības par mērāmajiem parametriem, lai aprakstītu sejas un deguna morfoloǵiju. Par spīti daudz un dažādiem mērījumiem un antropometriskiem punktiem, kuri tika lietoti sejas estētiskai novērtēšanai pacientiem ar lūpu un aukslēju šķeltnēm (Bagante \& Akota, 2015), tomēr daži mērījumi un punkti tika lietoti gandrīz visos pētījumos, piemēram, degungala punkts, deguna spārnu punkti, nāsu augstums (Farkas et al., 1993; Duffy et al., 2000; Yamada et al., 2002; Ferrario et al., 2003; Hood et al., 2004; Devlin et al., 2007; Weinberg et al., 2009; van Loon et al., 2010; Ayoub et al., 2011; Zreaqat et al., 2012). Šie biežāk lietotie antropometriskie punkti arī tika izvēlēti šajā pētījumā galvenokārt pamatojoties no Farkas ar kolēgiem (1993) pētījuma ar modifikācijām pēc Hood ar kolēǵiem (2004) un van Loon ar kolēgiem (2010). Visi 3D fotoattēli tika apstrādāti, lai šķeltne atrastos kreisajā pusē, pēc tam tika atlikti 25 antropometriski punkti un izmērīti 18 lineāri attālumi divas reizes ar vienas nedēḷas intervālu. Tā kā antropometrisko punktu atlikšana 3D fotoattēlos ir samērā laikietilpīgs process, tika izvēlēts pēc iespējas mazāks antropometrisko punktu skaits, bet lai tas būtu pietiekošs deguna un augšlūpas simetrijas noteikšanai un izmantojams klīnikā rutīnā. Līdzīgi kā van Loon ar kolẹgiem (2010), arī mēs sastapāmies ar grūtībām precīzi atlikt punktus subnazālā rajonā, jo nāsis bieži bija kḷūdu rajons, sarežǵîtās anatomijas dēl un kameras nespējas dēl uzṇemt tumšas ejas perfekti. Trīsdimensiju fotoattēlu rekonstrukcija šajā rajonā bija nedaudz neprecīza un anatomiskos punktus bija grūti atlikt. Lai varētu standartizēt punktu atlikšanu, automatizēts punktu atlikšanas rādītājs būtu noderīgs. Tik tiešām šādas automatizētas punktu atlikšanas metodes ir atrodamas rakstos, bet to pielietošana praksē joprojām nav populāra. Piemēram, Mishima ar kolēǵiem (2002) izmantoja precīzu kvantitatīvu metodi, lai mērītu deguna formu uz ğipša veiduḷiem, anatomiskos punktus atliekot pusautomātiski. Šo, pēc autoru domām, īpaši precīzo kontakt tipa 3D koordināšu mērīšanas aparātu izmantoja pieciem pacientiem (Mishima et al., 2002). Pigott R. W. un Pigott B. B. (2010) izveidoja SymNose programmu, lai efektīvi novērtētu deguna simetriju 2D fotoattēlos. Abas šīs metodes varētu būt daudzsološas, bet pagaidām ir eksperimentālā stadijā. Antropometrisko punktu atlikšanas mērījumu kḷūda nepārsniedza $3 \%$ no kopējās variācijas un sakrita ar iepriekš ziņotiem 
rezultātiem kā van Loon ar kolẹgiem (2010), kas secinājuši, ka neliela mērījumu kḷūda atliekot antropometriskos punktus neizraisa statistiski nozīmīgu mērījumu atšķirību.

Pētījumā tika pielāgots Amaratunga (1988) izmantotais šķelțu lūpas komponenta simetrijas indekss (CLCSI - cleft lip component symmetry index). Amaratunga (1988) savā darbā noteica nāsu simetriju, vermilion simetriju, lūpu loka simetriju, lūpas augstumu, mērot attālumus milimetros ar smalku kaliperu klīniski uz pacientiem. Pēc tam šos attālumus izmantoja, lai aprēksinātu dažādo lūpas un deguna komponentu simetrijas indeksu. Simetrijas indekss tika aprēķināts pēc formulas: attālums šķeltnes pusē pret attālumu veselajā pusē reizinot ar 100. Perfektu simetriju raksturotu vērtība 100, bet vērtība mazāka, vai lielāka par 100 raksturotu asimetrijas pakāpi. Asimetrijas pakāpi Amaratunga (1988) bija noteicis statistiski aprēķinot novirzi no ideālās vērtības, ja p > 0,05, tad nozīmīga atšķirība nebija. Pētījumā tika izmantots simetrijas indekss visiem deguna un augšlūpas mērījumiem 3D fotoattēlos pēc iepriekš aprakstītās formulas.

Protams, bez estētikas ļoti svarīga ir arī elpošanas funkcija, kuru vislabāk būtu novērtēt kopā, kā Huempfner-Hierl ar kolēǵiem (2009) pētījumā, kur tika novērtēta gan elpošanas funkcija ar aktīvu priekšeju rinomanometriju, rinorezistometriju un akustisko rinometriju, gan deguna estētika, nosakot 57 antropometriskos leņ̧̧us un līnijas izejot no 54 antropometriskiem punktiem 2D fotogrāfijās 3 pozīcijās (Huempfner-Hierl et al., 2009). Šajā pētījumā iekḷāvām gan elpošanas funkcijas noteikšanu, gan deguna simetrijas mērījumus 3D fotoattēlos. Atškirībā no Huempfner-Hierl ar kolēgiem (2009) pētîjuma, mūsu pētījumā tika noteikta deguna simetrija 3D fotoattēlos un tika izmantota kontroles grupa elpošanas funkcijas un deguna simetrijas salīdzināšanai. Cohen ar kolēgiem (2003) norāda, ka pārsteidzoši maza uzmanība tiek pievērsta deguna deformācijas funkcionālajiem aspektiem un funkcionālajam iznākumam pēc rekonstruktīvajām operācijām, kaut arī ir labi zināms, ka ievērojams pacientu skaits ar vienpusēju caurejošu lūpas, alveolārā izauguma un aukslēju šķeltni cieš no deguna elpceļu obstrukcijas, kam var būt nozīmīga ietekme deguna fizioloğijai un pacientu dz̄̄ves kvalitātei (Cohen et al., 2003). Rinomanometrija ir biežāk lietotā tehnika, kuru lieto, lai noteiktu deguna kvantitatīvo funkciju, aţ̦aujot mērīt deguna rezistenci un minimālo deguna šķērsgriezuma laukumu (Fukushiro \& Trindade, 2005). Savukārt Andre ar kolēgiem (2009), analizējot uz pierādījumiem balstītus rakstus, secināja, ka joprojām nav pierādīta korelācija starp rinomanometriju un indivīda subjektīvo elpošanas traucējumu sajūtu (Andre et al., 2009). Biežākā deguna elpceḷu obstrukcija ir starpsienas deviācija. Tā kā starpsienas deviācija ir bieža anatomiska variācija arī veseliem indivīdiem, bieži tiek diskutēts cik lielā mērā starpsienas deviācija ir klīniski nozīmīga, kas izraisa deguna elpceḷu obstrukciju. Tas nozīmē, ka daudziem cilvēkiem ar starpsienas novirzi nav apgrūtināta elpošana caur degunu (Kim et al., 2014). 
Lai gan šajā jomā nav vienotas nostājas, tomēr vairāki autori rinomanometriju veica pacientiem pirms un pēc, vai tikai pēc deguna korekcijas, secinot, ka rinomanometrija ir samērā objektīva metode, lai kvantitatīvi noteiktu deguna elpošanas funkciju (Trindade et al., 2009; HuempfnerHierl et al., 2009). Sandham un Murray (1993) veica rinomanometriju un tiešu starpsienas vizuālu priekšēju rinoskopiju. Dusková ar kolēgiem (2002) noteica deguna elpošanas funkciju pacientiem ar šķeltnēm pirms sekundāras deguna korekcijas un salīdzināja tos ar Bachmann (1983) noteiktajiem standartiem (Dusková et al., 2002). Mani ar kolēǵiem (2010) uzsver, ka svarīgi ir ne tikai objektīvie mērījumi, bet arī indivīda subjektīvās sūdzības (Mani et al., 2010). To novērojām arī savā pētījumā, jo daudziem pacientiem ar vienpusēju caurejošu lūpas, alveolārā izauguma un aukslēju šķeltni nebija izteiktu sūdzību par elpošanas funkcijas traucējumiem, lai gan rinomanometrijas dati uzrādīja obstrukcijas pazīmes. Savukārt Kunkel ar kolēgiem (1997) uzsver, ka pacientiem ar šķeltnēm, kuriem ir jāveic daudzi nekomfortabli izmeklējumi ilgstošas multidisciplināras ārstēšanas laikā īpaši svarīgi ir lietot neinvazīvas izmeklēšanas metodes, kā rinomanometrija. Savā darbā nesaskarāmies ar grūtībām veikt rinomanometrijas izmeklējumus bērniem ar vienpusēju caurejošu lūpas, alveolārā izauguma un aukslēju šķeltni un kontroles grupas bērniem. Bērni viegli saprata un izpildīja uzdevumu.

\subsection{Pētījuma rezultātu interpretācija}

Deguna estētikas novērtēšanai 2D fotoattēlos tika iekļautas divas novērtēšanas metodes - ar detalizēto vērtēšanas skalu un ar vizuālo analogu skalu. Pētījuma rezultātos darbā ar pielāgoto Anastassov un Chipkov (2003) izstrādāto shēmu, rezultātu summa svārstījās no 0 līdz 3 punktiem. Tādas deformācijas kā "šaura nāsu pamatne", "kolumellas pamatne pārāk šaura", "saplacināts un hipoplastisks spārns" nevienam pacientam netika atzīmēts. Visbiežāk tika atzīmētas "nāsu augšējās malas deformācija" un "plata nāsu pamatne", bet to variabilitāte bija visaugstākā. Viena novērtētāja atšķirība starp divām novērtēšanas reizēm (intra novērtētāja variabilitāte) bija samērā zema, tātad ar labiem ticamības rādītājiem, bet atšķirīiba starp vairākiem novērtētājiem bija ar lielāku inter novērtētāja variabilitāti, kas norāda par metodes subjektīvo dabu. Domājams, ka pētījuma pirmās daļas iekḷauto pacientu skaits un iespējamās 2D fotoattēlu nepilnības (fotoattēlos detalizētās deformācijas varētu nebūt tik skaidri saskatāmas) ietekmējušas statistisko ticamību. Lai gan novērtētāji pirms novērtēšanas tika sagatavoti un iepazīstināti ar pielāgoto Anastassov un Chipkov (2003) izstrādāto deguna estētikas novērtēšanas skalu, tomēr atsevišksas pozīcijas varētu tikt interpretētas atškirīgi, piemēram, neliela nāsu augšējās malas deformācija vienā novērtēšanas reizē atzīmēta kā esoša, bet otrā reizē novērtētājam šķitis, kas augšējās malas deformācijas nebija. Pētījumos, kuros bija 
lielāks pacientu skaits, deguna estētikas novērtējums 2D fotoattēlos ar dažādām metodēm uzrādīja labus ticamības rādītājus, piemēram, Pitak-Arnnop ar kolēǵiem (2011) apsekoja 50 pacientus. Savukārt Anastassov un Chipkov (2003) deguna un lūpas estētiku novērtēja klīniski uz pacientiem, kas izslēdza iespējamo fotoattēlu kḷūdu. Kā arī Anastassovs mērījumus veica viens pats, vienu reizi, izslēdzot inter un intra novērtētāja variabilitāti.

Novērtēšana ar VAS izrādījās l̦oti subjektīva un variabla, gan novērtējot vienam vērtētājam labo un kreiso pusi, gan savstarpēji starp vērtētājiem. Mutes, sejas un žokḷu ķirurgs, kurš operē šķeltnes vidēji bija viszemāk novērtējis deguna estētiku, bet visaugstāk autors. VAS vērtējumā rezultātu ticamību ietekmē tikai cilvēciskais faktors, jo tā balstās pēc ,patīk”, „nepatīk” principa. Tāpēc pētījumos to izmanto samērā reti un bieži kopā ar vēl kādu estētiskās novērtēšanas metodi. Šì metode ir laba, ja jānovērtē nespeciālista viedoklis, piemēram, pašu pacientu novērtējums, kā to savā pētījumā ir veicis Sinko ar kolēgiem (2005), kur VAS izmantota, lai salīdzinātu pacientu pašnovērtējumu ar ķirurgu novērtējumu (Sinko et al., 2005). Arī Oosterkamp ar kolēgiem (2007) izmantoja VAS, lai pacienti paši novērtētu savu izskatu un funkciju. Oti ar kolēgiem (2014) izmantoja VAS, lai novērtētu deguna estētiku pacientu vecāki, personas no malas un ķirurgi. Ir pētījumi, kuros VAS ir uzrādījis labus statistiski ticamus rezultātus. Piemēram, Bongaarts ar kolēǵiem (2008) VAS izmantoja, lai noteiktu deguna estētiku divdimensiju fotoattēlos, profesionāḷ un personas no malas, ar labiem ticamības rezultātiem. Stebel ar kolēǵiem (2016) izmantoja VAS, lai salīdzinātu deguna estētiku nosakot 2D un 3D fotoattēlos, VAS uzrādīja labus ticamības rezultātus īpaši mērījumos 3D fotoattēlos. Arī Desmedt ar kolẹgiem (2015) izmantoja VAS, lai noteiktu deguna un lūpas estētiku 3D fotoattēlos ar labiem ticamības rezultātiem. Domājams, ka vizuālo analogu skala varētu tikt izmantota nosakot pašu pacientu un vecāku apmierinātību ar pēc operācijas rezultātiem, jo tās lietošana ir ērta, lēta un viegli saprotama.

Pētījuma rinomanometrijas rezultāti saskanēja ar literatūrā aprakstītajiem pētījumiem, kuros salīdzināta šķeltņu pacientu elpošana ar kontroles grupu. Elpošanas plūsma pacientiem ar vienpusēju caurejošu lūpas, alveolārā izauguma un aukslēju šķeltni bija vājāka, nekā veseliem bērniem (Kunkel et al., 1997; Fukushiro \& Trindade, 2005; Mani et al., 2010). Rinomanometrijas pētījumi uzrāda palielinātu gaisa plūsmas rezistenci šķeltnes pusē dēḷ starpsienas deviācijas un samazinātu gaisa plūsmas rezistenci veselajā pusē. Tomēr četros gadījumos bērniem ar vienpusēju caurejošu lūpas, alveolārā izauguma un aukslēju šķeltni elpošanas plūsma caur šķeltnes pusi bija labāka nekā caur ne šķeltnes pusi, par spīti starpsienas novirzei, šo terminu sauc par paradoksālu deguna obstrukciju. To izskaidro kā samazinātu gaisa plūsmu kontralaterālajā pusē, ko izraisa obstrukcija no kompensatoras apakšējās konhas hipertrofijas (Ridgway et al., 2011). Kā arī traucēta elpošanas plūsma varētu būt saistīta ne tikai 
ar starpsienas stāvokli, bet arī ar citām otorinolaringoloǵiskām orgānu patoloǵijām. Reiser ar kolēǵiem (2011) norāda, ka pacientiem ar šķeltnēm deguna elpošanas funkcijas traucējumus izraisa vairāki iemesli kā starpsienas deviācija, hipertrofētas gliemežnīcas, deguna polipi, mugurējās konhas deficīts, adenoīdu audi, mandeles, šauras un/ vai samazinātas nāsis vai intranazālas striktūras. Pēc rinomanometrijas rezultātiem, bērniem ar elpošanas traucējumiem iespējams būtu jāparedz papildus deguna elpošanu koriǵējošas operācijas, bet nav zināms cik lielā mērā tās spētu uzlabot deguna elpošanu. Cohen ar kolēǵiem (2003) secinājuši, ka labāki elpošanas funkcijas un estētiskie rezultāti tika sasniegti tiem pacientiem, kuriem bija mazāks operāciju skaits. Pacientiem ar vairākām koriǵējošām operācijām, ievērojamu rētošanās procesu un audu deficītu, tika novēroti sliktāki estētiskie rezultāti un ar sliktiem vai niecīgiem deguna elpošanas funkcijas uzlabojumiem. To izskaidro ar audu kontraktūru un rētaudu relatīvi mazu audu elasticitāti elpošanas laikā (Cohen et al., 2003). Tāpat arī Cohen ar kolēgiem (2003) norāda, ka pacientiem ar vienpusēju caurejošu lūpas, alveolārā izauguma un aukslēju šķeltni pie deguna korekcijas ir nepieciešams ņemt vērā iepriekšējās operācijas, rētošanās procesu, kas var radīt jatrogēnas deformācijas. Mūsu pētījumā netika pierādīta tieša saistība starp deguna elpošanas plūsmu un operāciju skaitu.

Pētījuma rezultāti antropometriskajos mērījumos 3D fotoattēlos parādīja, ka atšķirība bērniem ar vienpusēju caurejošu lūpas, alveolārā izauguma un aukslēju šķeltni starp šķeltnes un veselo pusi nebija statistiski ticama, izṇemot deguna spārna garumam (al-PRN), kas norāda, ka tika sasniegta apmierinoša deguna simetrija pēc sekundārām deguna korekcijām pirmsskolas vecumā un arī tiem bērniem, kuriem sekundāra deguna korekcija tika uzskatīta, ka nav nepieciešama. Kontroles grupā atšķirība starp labo un kreiso deguna pusi nebija statistiski ticama, tātad varētu uzskatît, ka deguns bija simetrisks. Atšķirība starp pētījuma grupu un kontroles grupu bija statistiski ticama visās antropometriskajās distancēs izņemot lūpas garumam līdz lūpu lociņam abās pusēs (chR-cphR, chL-cphL). Iemesls šādai atšķirībai varētu būt vecuma, auguma un dzimuma atšķirīibas. Pētījuma grupas pacientu vidējais vecums bija 14 gadi, robežās no 10-18 gadiem, savukārt kontroles grupai vidējais vecums bija 10 gadi. Pacientu sadalījums pēc dzimuma bija samērā līdzvērtīgs gan pētījuma grupā (15 zēni un 15 meitenes), gan kontroles grupā (18 zēni un 17 meitenes). Mūsu rezultāti sakrīt arī ar citu autoru publicētiem pētîjumiem (Duffy et al., 2000; Yamada et al., 2002; Ferrario et al., 2003; Hood et al., 2004; Ayoub et al., 2011; Okawachi et al., 2011; Zreaqat et al., 2012). Duffy ar kolēgiem (2000) savā pētījumā konstatēja ievērojamu atšķkirību deguna pamatnes platumā starp kontroles grupu un škseltņu grupu. Ferrario ar kolēǵiem (2003) secināja, ka šķeltņu grupa atšķīrās no kontroles grupas un, ka konkrētās ķirurğijas metodes nespēja nodrošināt pilnībā harmonisku sejas izskatu. Hood ar kolēgiem (2004) arī konstatēja saplacinātu deguna spārnu 
šķeltnes pusē. Ayoub ar kolēgiem (2011) arī konstatēja līdzīgas atšķirības starp šķeltnes un kontroles grupu, kā mūsu pētījumā un arī Yamada ar kolēǵiem (2002) atrada atš̌sirības starp šķeltnes un veselo pusi šķeltņu grupā. Savukārt Zreaqat ar kolēǵiem (2012) savā pētījumā pierādīja, ka ievērojamas atšksirības deguna un lūpas rajonā starp šķeltņu un kontroles grupu ir atrodamas arī, ja grupas ir atlasītas līdzvērtīgi gan pēc pacientu auguma, svara un vecuma. Arī Ferrario ar kolēgiem (2003) secināja, ka sejas mīksto audu struktūras pieaugušajiem ar vienpusēju caurejošu lūpas, alveolārā izauguma un aukslēju šķeltni atšķīrās no kontroles grupas viena vecuma, dzimuma un etniskās grupas ietvaros (Ferrario et al., 2003).

Lai arī statistiski ticama atškşirỉba pētījuma grupā starp šķeltnes un veselo pusi bija tikai starp deguna spārna garumu, tomēr simetrijas indekss uzrādīja statistiski ticamu asimetrijas pakāpi gan deguna spārna garumam (al-PRN), gan arī deguna sānu garumam (al-N) un lūpas loka attālumam līdz viduslīnijai (cph-cM). Tāpat arī kontroles grupā tika novērota simetrijas indeksa statistiski ticama asimetrija nāsu augstumam (nl-nd), kas netika uzrādīta analizējot deguna nāsu augstuma attālumus absolūtos skaițos. Interesanti, ka pētījuma grupā, bija panākta labāka nāsu augstuma simetrija nekā kontroles grupā bērniem bez iedzimtas lūpas un aukslēju šķeltnes. Tas varētu norādīt, ka simetrijas indekss precīzāk nosaka simetriju, tas ir matemātisks mākslīgi izveidots indekss. Tomēr kā raksta Bell ar kolēǵiem (2014) tas, ka seja nav pilnībā simetriska jau ir vispār pieņemts fakts. Kā arī piln̄̄bā simetriska seja nav estētiska, tā secinājuši Peck H. un Peck S. (1970) savā darbā novērtējot sejas simetriju sava laika skaistuma karalienēm, profesionālām modelēm un citām skaistām sievietēm. Autori seju pa viduslīniju pārdalīja uz pusēm un savienoja abas labās puses kopā izveidojot seju un abas kreisās puses kopā. Novērtējot visas trīs sejas - oriǵinālo un abas mākslīgās, secināja, ka tieši neliela sejas asimetrija raksturo estētiski pievilcīgu seju (Peck H. \& Peck S., 1970). Kā raksta Russell ar kolēgiem (2001) līdzsvars, simetrija un proporcijas ir sejas estētikas komponenti, kas dokumentēti jau 5000 gadu atpakal Ēg̣iptiešu kultūrā. Šie estētikas aspekti ir saglabājušies caur grieķu un romiešu kultūrām līdz mūsdienu sejas estētiskas un skaistuma standartiem (Russell et al., 2001). Tomēr simetrijas indekss labi noder, lai salīdzinātu pētījuma un kontroles grupas deguna un lūpas simetriju, jo pastāv gan vecuma, gan auguma variācijas, kas nepiel̦auj tiešu antropometrisko attālumu salīdzināšanu. Kā arī simetrijas indeksa vidējā vērtība parāda raksturīgākās operāciju rezultātu pazīmes antropometriskajiem attālumiem. Piemēram, lūpas loka attālums līdz viduslīnijai (cph-chM) vidēji pētījuma grupā bija garāks šķeltņu pusē, nekā veselajā pusē, lūpas garums līdz lūpu lociņa augstākajam punktam (ch-cph) vidēji bija vienāds starp šķ̧eltnes un veselo pusi, baltās lūpas garums (Sbal-cph) vidēji šķeltnes pusē bija īsāks, arī nāsu augstums (nl-nd) škseltnes pusē bija īsāks, kas ir raksturīga pazīme pacientiem ar vienpusēju caurejošu lūpas, alveolārā izauguma un aukslēju šķeltni, ka ir nedaudz saplacināta 
nāss šķeltnes pusē. Nāsu platums pie deguna pamatnes (al-Sn) vidēji bija vienāds starp šķeltnes un veselo pusi, bet deguna garums sānu pusē (al-N) un deguna spārna garums (al-PRN) vidēji bija īsāki škseltnes pusē nekā veselajā pusē. Simetrijas indekss palīdz noteikt tipiskākās operāciju rezultātu novirzes pacientiem ar šķeltnēm un varētu palīdzēt novērtēt ķirurǵisko operāciju rezultātus. Līdzịgi kā mūsu pētījumā, $L i$ ar kolēgiem (2010) bija noteikuši sejas izmērīto attālumu attiecības, izrēķinot indeksu. Kreisās puses attālums pret labās puses attālumu. $L i$ ar kolēgiem (2010) veiktajā literatūras analīzē konstatējuši, ka vairāki autori veikuši pētījumus ar veseliem cilvēkiem un secinājuši, ka neliela sejas asimetrija ir iedzimts fenomens un absolūta simetrija nav raksturīga. Viņi arī secinājuši, ka veseliem cilvēkiem vinu lietotais estētikas indekss ir robežās no 90-110\% un šis diapazons tika uzskatîts par simetrisku seju. Ja pacientiem ar šķeltnēm šis estētikas indekss degunam un lūpai bija robežās no 90-110\%, tad tika uzskatīts, ka ķirurgijijas rezultāts ir izdevies (Li et al., 2010). Ja ņem vērā $L i$ ar kolēgiem (2010) piedāvāto simetrijas indeksa interpretāciju, tad mūsu pētījumā iesaistītajiem pacientiem ar vienpusēju caurejošu lūpas, alveolārā izauguma un aukslēju šķeltni bija izdevies ķirurğijas rezultāts, jo vidējais simetrijas indekss bija robežās no 95-110\%. Kontroles grupas vidējais simetrijas indekss bija robežās no 96-103\%.

Russell ar kolēgiem (2009) norāda, ka nav skaidrs vai mainīgo lielumu statistiski nozīmīga atšķirīiba ir arī ar klīniski svarīgu nozīmību. Viena no klīniski nozīmīgajām vadlīnijām varētu tikt uzskatīta pamatojoties no $L u$ (1965) ziņojuma, ka asimetrijas lielākas par 3\% ir klīniski pamanāmas (Russell et al., 2009). Savukārt Othman ar kolẹgiem (2014) savā darbā pirmie piedāvā, ka klīniski nozīmīga asimetrija, kas izteikta milimetros ir lielāka vai vienāda par $5 \mathrm{~mm}$. Tas nozīmēe, ka klīniski var noteikt asimetriju pacientiem ar vienpusēju caurejošu lūpas, alveolārā izauguma un aukslēju šķeltni, ja tā ir lielāka vai vienāda par $5 \mathrm{~mm}$ salīdzinot ar veseliem indivīdiem (Othman et al., 2014).

Estētika varētu būt vairāku sejas pazīmju akumulācijas interpretācija un, iespējams, ka joprojām estētika nav izmērāma ar specifiskiem objektīviem mērījumiem pacientiem ar vienpusēju caurejošu lūpas, alveolārā izauguma un aukslēju šķeltni (Russell et al., 2009). Deguna elpceḷu obstrukcijas pakāpes ir dažādas un tām nav tiešas korelācijas ar deguna deformācijas smaguma pakāpi (Cohen et al., 2003). To novērojām arī šajā pētījumā, kad netika pierādīta pārliecinoša saistība starp deguna simetriju 3D fotoattēlos un elpošanas funkciju. 


\section{SECINĀJUMI}

1. Deguna estētikas novērtējums ar modificēto Anastassov un Chipkov (2003) vērtēšanas skalu bija ar augstu gan intra, gan inter novērtētāju variabilitāti. Šīs vērtēšanas skalas lietošana divdimensiju fotoattēlos izvēlētajai pacientu grupai bija subjektīva un nebija lietojama grupu salīdzināšanai.

2. Deguna estētikas novērtēšana divdimensiju fotoattēlos ar vizuālo analogu skalu izvēlētajai pacientu grupai bija subjektīva metode.

3. Pacientiem ar vienpusēju caurejošu lūpas, alveolārā izauguma un aukslēju šķeltni pēc rinoplastikas elpošanas plūsma caur veselo pusi vidēji bija ar vieglu obstrukciju, bet caur šķeltnes pusi ar smagu obstrukciju. Kontroles grupā elpošanas plūsma vidēji caur labo un kreiso nāsi bija ar vieglu obstrukciju. Rinomanometrija bija ērta un objektīva metode deguna funkcijas noteikšanai bērniem no 10 gadu vecuma.

4. Vērtējot 3D fotoattēlus, deguna un augšlūpas simetrija tika atjaunota bērniem ar vienpusēju caurejošu lūpas, alveolārā izauguma un aukslēju škseltni pēc deguna korekcijām pirmsskolas vecumā, kaut arī simetrija starp pētījuma un kontroles grupu atšķ̄îās. Simetrijas indekss palīdzēja salīdzināt pētîjuma un kontroles grupas deguna un augšlūpas asimetriju.

5. Deguna un augšlūpas novērtēšana trīsdimensiju fotoattēlos ar piedāvāto antropometrisko punktu apjomu bija ērta un precīza metode, lai novērtētu pēc operācijas rezultātus izvēlētajai pacientu grupai, bet deguna estētikas novērtējums divdimensiju fotoattēlos ar izvēlētajām novērtēšanas metodēm uzrādīja subjektīvus rezultātus. Turpmāk deguna simetrijas noteikšanai būtu nepieciešams izmantot 3D fotoattēlus. 


\section{PRAKTISKĀS REKOMENDĀCIJAS}

1. Bērniem ar vienpusēju caurejošu lūpas, alveolārā izauguma un aukslēju šķeltni pēc operācijas rezultātu novērtēšanai rekomendējams veikt 3D fotografěšanu rutīnā no 10 gadu vecuma.

2. Pētījumā lietotie antropometriskie punkti un attālumi rekomendējami lietot ikdienas darbā klīnikā, lai novērtētu deguna un augšlūpas simetriju.

3. Bērniem ar vienpusēju caurejošu lūpas, alveolārā izauguma un aukslēju šķeltni rekomendējams veikt deguna elpošanas funkcijas noteikšanu ar priekšēju rinomanometriju rutīnā no 10 gadu vecuma. 


\section{IZMANTOTĀ LITERATŪRA}

1. Akota, I., Barkāne, B. un Grasmane, N. 2001. Iedzimto sejas šķeltņu biežuma rādītāji Latvijā no 1960. līdz 1997. gadam. ZRaksti/LMA. 166-170.

2. Barkāne, B. 1997. Lūpu un aukslēju šķelț̣u izplatība un to radītie traucējumi. Zobārstniecības raksti. 15(2), 16-18.

3. Jākobsone, G. 2003. Dentofaciālā morfoloǵija un oklūzija bērniem ar deguna elpošanas patologiju. Promocijas darbs, RSU, Rīga. 3-33.

4. Abbott, M. M. and Meara, J. G. 2012. Nasoalveolar Molding in Cleft Care. Plastic and Reconstructive Surgery. 130(3), 659-666.

5. Ahuja, R. B. 2001. Radical correction of secondary nasal deformity in unilateral cleft lip patients presenting late. Plastic and Reconstructive Surgery. 108(5), 1127-1135.

6. Ahuja, R. B. 2002. Primary definitive nasal correction in patients presenting for late unilateral cleft lip repair. Plastic and Reconstructive Surgery. 110, 17-24.

7. Ayoub, A., Garrahy, A., Millett, D., Bowman, A., Siebert, J. P., Miller, J. and Ray, A. 2011. Three-dimensional assessment of early surgical outcome in repaired unilateral cleft lip and palate: part 1. Nasal changes. The Cleft Palate-Craniofacial Journal. 48, 571-577.

8. Al-Omari, I., Millett, D. T., Ayoub, A. F., Bock, M., Ray, A., Dunaway, D. and Crampin, L. 2003. An appraisal of three methods of rating facial deformity in patients with repaired complete unilateral cleft lip and palate. The Cleft Palate-Craniofacial Journal. 40(5), 530-537.

9. Al-Omari, I., Millett, D. T. and Ayoub, A. F. 2005. Methods of assessment of cleft-related facial deformity: a review. The Cleft Palate-Craniofacial Journal. 42(2), 145-156.

10. Alonso, N., Risso, G. H., Denadai, R. and Raposo-Amaral, C. E. 2014. Effect of maxillary alveolar reconstruction on nasal symmetry of cleft lip and palate patients: a study comparing iliac crest bone graft and recombinant human bone morphogenetic protein-2. Journal of Plastic, Reconstructive \& Aesthetic Surgery. 67(9), 1201-1208.

11. Amaratunga, N. A. de S. 1988. A comparison of Millard's and LeMesurier's methods of repair of the complete unilateral cleft lip using a new symmetry index. Journal of Oral and Maxillofacial Surgery. 46(5), 353-356.

12. Anastassov, G. E., Joos, U. and Zöllner, B. 1998. Evaluation of the results of delayed rhinoplasty in cleft lip and palate patients. Functional and aesthetic implications and factors that affect successful nasal repair. The British Journal of Oral \& Maxillofacial Surgery. 36, 416-424.

13. Anastassov, Y. and Chipkov, C. 2003. Analysis of nasal and labial deformities in cleft lip, alveolus and palate patients by a new rating scale: preliminary report. Journal of Cranio-MaxilloFacial Surgery. 31(5), 299-303.

14. Anderl, H., Hussl, H. and Ninkovic, M. 2008. Primary simultaneous lip and nose repair in the unilateral cleft lip and palate. Plastic and Reconstructive Surgery. 121(3), 959-970.

15. Andre, R. F., Vuyk, H. D., Ahmed, A., Graamans, K. and Nolst Trenite, G. J. 2009. Correlation between subjective and objective evaluation of the nasal airway. A systematic review of the highest level of evidence. Clinical Otolaryngology. 34, 518-525.

16. Asher-McDade, C., Brattstrom, V., Dahl, E., McWilliam, J., Molsted, K., Plint, D. A., PrahlAndersen, B., Semb, G., Shaw, W. C. and The, R. P. 1992. A Six-Center International Study of Treatment Outcome in Patients with Clefts of the Lip and Palate: Part 4. Assessment of Nasolabial Appearance. The Cleft Palate-Craniofacial Journal. 29(5), 409-412.

17. Asher-McDade, C., Roberts, C., Shaw, W. C. and Gallager, C. 1991. Development of a method for rating nasolabial appearance in patients with clefts of the lip and palate. Cleft PalateCraniofacial Journal. 28(4), 385-390.

18. Bachmann, W. 1983. Clinical functional diagnosis of obstructed nasal respiration. HNO. 31(9), 320-326.

19. Bagante, I. and Akota, I. 2015. Cleft-related nose deformation evaluation and measurement methods. Literature review. Stomatologija. 17(3), 75-83.

20. Balaji, S. M. 2003. One-stage correction of severe nasal deformity associated with a unilateral cleft lip. Scandinavian Journal of Plastic and Reconstructive Surgery and Hand Surgery. 37(6), 332-338. 
21. Barillas, I., Dec, W., Warren, S. M., Cutting, C. B. and Grayson, B. H. 2009. Nasoalveolar molding improves long-term nasal symmetry in complete unilateral cleft lip-cleft palate patients. Plastic and Reconstructive Surgery. 123, 1002-1006.

22. Bearn, D. R., Sandy, J. R. and Shaw, W. C. 2002a. Cephalometric soft tissue profile in unilateral cleft lip and palate patients. European Journal of Orthodontics. 24(3), 277-284.

23. Bearn, D. R., Sandy, J. R. and Shaw, W. C. 2002b. Photogrammetric assessment of the soft tissue profile in unilateral cleft lip and palate. The Cleft Palate-Craniofacial Journal. 39(6), 597-603.

24. Becker, M., Svensson, H. and Jacobsson, S. 1998. Clinical examination compared with morphometry of digital photographs for evaluation of repaired cleft lips. Scandinavian Journal of Plastic and Reconstructive Surgery and Hand Surgery. 32(3), 301-306.

25. Bell, A., Lo, T. W. R., Brown, D., Bowman, A. W., Siebert, J. P., Simmons, D. R., Millett, D. T. and Ayoub, A. F. 2014. Three-dimensional assessment of facial appearance following surgical repair of unilateral cleft lip and palate. The Cleft Palate-Craniofacial Journal. 51(4), 462-471.

26. Bilwatsch, S., Kramer, M., Haeusler, G., Schuster, M., Wurm, J., Vairaktaris, E., Neukam, F. W. and Nkenke, E. 2006. Nasolabial symmetry following Tennison-Randall lip repair: a threedimensional approach in 10-year-old patients with unilateral clefts of lip, alveolus and palate. Journal of Cranio-Maxillo-Facial Surgery. 34(5), 253-262.

27. Byrd, H. S., El-Musa, K. A. and Yazdani, A. 2007. Definitive repair of the unilateral cleft lip nasal deformity. Plastic and Reconstructive Surgery. 120(5), 1348-1356.

28. Byrd, H. S. and Salomon, J. 2000. Primary correction of the unilateral cleft nasal deformity. Plastic and Reconstructive Surgery. 106(6), 1276-1286.

29. Byrne, M., Chan, J. C. Y. and O’Broin, E. 2014. Perceptions and satisfaction of aesthetic outcome following secondary cleft rhinoplasty: evaluation by patients versus health professionals. Journal of Cranio-Maxillo-Facial Surgery. 42(7), 1062-1070.

30. Bongaarts, C. A. M., Prahl-Andersen, B., Bronkhorst, E. M., Spauwen, P. H. M., Mulder, J. W., Vaandrager, J. M. and Kuijpers-Jagtman, A. M. 2008. Effect of infant orthopedics on facial appearance of toddlers with complete unilateral cleft lip and palate (Dutchcleft). The Cleft PalateCraniofacial Journal. 45(4), 407-413.

31. Brattström, V., Mølsted, K., Prahl-Andersen, B., Semb, G. and Shaw, W. C. 2005. The Eurocleft study: intercenter study of treatment outcome in patients with complete cleft lip and palate. Part 2: craniofacial form and nasolabial appearance. The Cleft Palate-Craniofacial Journal. 42(1), 69-77.

32. Brussé, C. A., Van der Werff, J. F., Stevens, H. P., Vermeij-Keers, C., Prahl-Andersen, B., Van der Meulen, J. C. and Vaandrager, J. M. 1999. Symmetry and morbidity assessment of unilateral complete cleft lip nose corrected with or without primary nasal correction. The Cleft PalateCraniofacial Journal. 36(4), 361-366.

33. Bugaighis, I., Mattick, C. R., Tiddeman, B. and Hobson, R. 2014a. 3D asymmetry of operated children with oral clefts. Orthodontics \& Craniofacial Research. 17(1), 27-37.

34. Bugaighis, I., Mattick, C. R., Tiddeman, B. and Hobson, R. 2014b. 3D facial morphometry in children with oral clefts. The Cleft Palate-Craniofacial Journal. 51(4), 452-461.

35. Bugaighis, I., Tiddeman, B., Mattick, C. R. and Hobson, R. 2014c. 3D comparison of average faces in subjects with oral clefts. European Journal of Orthodontics. 36(4), 365-372.

36. Carstens, M. H. 1999. Correction of unilateral cleft lip nasal deformity using the sliding sulcus procedure. The Journal of Craniofacial Surgery. 10(4), 346-364.

37. Chaithanyaa, N., Rai, K. K., Shivakumar, H. R. and Upasi, A. 2011. Evaluation of the outcome of secondary rhinoplasty in cleft lip and palate patients. Journal of Plastic, Reconstructive \& Aesthetic Surgery. 64(1), 27-33.

38. Chang, C. S., Liao, Y. F., Wallace, C. G., Chan, F. C., Liou, E. J. W., Chen, P. K. T. and Noordhoff, M. S. 2014. Long-term comparison of the results of four techniques used for bilateral cleft nose repair: a single surgeon's experience. Plastic and Reconstructive Surgery. 134(6), 926-936.

39. Chang, C. S., Por, Y. C., Liou, E. J. W., Chang, C. J., Chen, P. K. T. and Noordhoff, M. S. 2010. Long-term comparison of four techniques for obtaining nasal symmetry in unilateral complete cleft lip patients: a single surgeon's experience. Plastic and Reconstructive Surgery. 126(4), 1276-1284. 
40. Cheon, Y. W. and Park, B. Y. 2010. Long-term evaluation of elongating columella using conchal composite graft in bilateral secondary cleft lip and nose deformity. Plastic and Reconstructive Surgery. 126(2), 543-553.

41. Chetpakdeechit, W., Wahss, J., Woo, T., Hugander, M., Mohlin, B. and Hagberg, C. 2011. Esthetic views on facial and dental appearance in young adults with treated bilateral cleft lip and palate (BCLP). A comparison between professional and non-professional evaluators. Swedish Dental Journal. 35, 151-157.

42. Cho, B. C. 2006. Unilateral Complete Cleft Lip and Palate Repair Using Lip Adhesion Combined with a Passive Intraoral Alveolar Molding Appliance: Surgical Results and the Effect on the Maxillary Alveolar Arch. Plastic and Reconstructive Surgery. 117(5), 1510-1529.

43. Cho, B. C. and Baik, B. S. 2001. Correction of cleft lip nasal deformity in Orientals using a refined reverse-U incision and V-Y plasty. British Journal of Plastic Surgery. 54(7), 588-596.

44. Chowchuen, B., Keinprasit, C. and Pradubwong, S. 2010a. Primary unilateral cleft lip-nose repair: the Tawanchai cleft center's integrated and functional reconstruction. Journal of the Medical Association of Thailand. 93(4) 34-45.

45. Chowchuen, B., Viwattanatipa, N., Wangsrimongkol, T. and Pradubwong, S. 2010b. Primary bilateral cleft lip-nose repair: the Tawanchai Cleft Center's integrated and functional reconstruction. Journal of the Medical Association of Thailand. 93(4) 46-57.

46. Clark, S. L., Teichgraeber, J. F., Fleshman, R. G., Shaw, J. D., Chavarria, C., Kau, C. H., Gateno, J. and Xia, J. J. 2011. Long-Term Treatment Outcome of Presurgical Nasoalveolar Molding in Patients With Unilateral Cleft Lip and Palate. Journal of Craniofacial Surgery. 22(1), 333-336.

47. Cohen, M., Smith, B. E. and Daw, J. L. 2003. Secondary unilateral cleft lip nasal deformity: functional and esthetic reconstruction. The Journal of Craniofacial Surgery. 14(4), 584-593.

48. Dadáková, M., Cagáňová, V., Dupej, J., Hoffmannová, E., Borský, J. and Velemínská, J. 2016. Three-dimensional evaluation of facial morphology in pre-school cleft patients following neonatal cheiloplasty. Journal of Cranio-Maxillo-Facial Surgery. 44(9), 1109-1116.

49. Daelemans, A., Leloup, T., Decaesteker, C. and De Mey, A. 2006. New digital method for quantitative assessment of nasal morphology. Scandinavian Journal of Plastic and Reconstructive Surgery and Hand Surgery. 40(6), 335-344.

50. Dahlberg, G. 1940. Statistical Methods for Medical and Biological Students. London: George Allen \& Unwin Ltd. 122-132.

51. Desmedt, D. J., Maal, T. J., Kuijpers, M. A., Bronkhorst, E. M., Kuijpers-Jagtman, A. M. and Fudalej, P. S. 2015. Nasolabial symmetry and esthetics in cleft lip and palate: analysis of 3D facial images. Clinical Oral Investigations. 19(8), 1833-1842.

52. Devlin, M. F., Ray, A., Raine, P., Bowman, A. and Ayoub, A. F. 2007. Facial symmetry in unilateral cleft lip and palate following alar base augmentation with bone graft: a threedimensional assessment. The Cleft Palate-Craniofacial Journal. 44(4), 391-395.

53. Dissaux, C., Bodin, F., Grollemund, B., Picard, A., Vazquez, M. P., Morand, B., James, I., Kauffmann, I. and Bruant-Rodier, C. 2015. Evaluation of 5-year-old children with complete cleft lip and palate: Multicenter study. Part 1: Lip and nose aesthetic results. Journal of CranioMaxillo-Facial Surgery. 43(10), 2085-2092.

54. Duffy, S., Noar, J. H., Evans, R. D. and Sanders, R. 2000. Three-dimensional analysis of the child cleft face. The Cleft Palate-Craniofacial Journal. 37(2), 137-144.

55. Dusková, M., Kristen, M., Hronková, K. and Rákosník, P. 2002. Rhinomanometry in patients with a cleft deformity of the nose. Acta Chirurgiae Plasticae. 44, 124-128.

56. Dusková, M., Kristen, M. and Smahel, Z. 2006. The anthropometric verification of corrective surgery outcome in cleft secondary deformities. The Journal of Craniofacial Surgery. 17(3), 447-453.

57. Dutton, J. M. and Bumsted, R. M. 2001. Management of the cleft lip nasal deformity. Facial Plastic Surgery Clinics of North America. 9(1), 51-58.

58. Ezzat, C. F., Chavarria, C., Teichgraeber, J. F., Chen, J. W., Stratmann, R. G., Gateno, J. and Xia, J. J. 2007. Presurgical Nasoalveolar Molding Therapy for the Treatment of Unilateral Cleft Lip and Palate: A Preliminary Study. The Cleft Palate-Craniofacial Journal. 44(1), 8-12.

59. Farkas, L. G., Hajnis, K. and Posnick, J. C. 1993. Anthropometric and anthroposcopic findings of the nasal and facial region in cleft patients before and after primary lip and palate repair. The Cleft Palate-Craniofacial Journal. 30(1), 1-12. 
60. Ferrari Júnior, F. M., Ayub, P. V., Capelozza Filho, L., Pereira Lauris, J. R. and Garib, D. G. 2015. Esthetic evaluation of the facial profile in rehabilitated adults with complete bilateral cleft lip and palate. Journal of Oral and Maxillofacial Surgery. 73(1), 169.e1-6.

61. Ferrario, V. F., Mian, F., Peretta, R., Rosati, R. and Sforza, C. 2007. Three-dimensional computerized anthropometry of the nose: landmark representation compared to surface analysis. The Cleft Palate-Craniofacial Journal. 44(3), 278-285.

62. Ferrario, V. F., Sforza, C., Dellavia, C., Tartaglia, G. M., Sozzi, D. and Carù, A. 2003. A quantitative three-dimensional assessment of abnormal variations in facial soft tissues of adult patients with cleft lip and palate. The Cleft Palate-Craniofacial Journal. 40(5), 544-549.

63. Fisher, D. M., Lo, L. J., Chen, Y. R. and Noordhoff, M. S. 1999. Three-dimensional computed tomographic analysis of the primary nasal deformity in 3-month-old infants with complete unilateral cleft lip and palate. Plastic and Reconstructive Surgery. 103(7), 1826-1834.

64. Fisher, D. M., Tse, R. and Marcus, J. R. 2008. Objective measurements for grading the primary unilateral cleft lip nasal deformity. Plastic and Reconstructive Surgery. 122(3), 874-880.

65. Flores, R. L., Sailon, A. M. and Cutting, C. B. 2009. A novel cleft rhinoplasty procedure combining an open rhinoplasty with the Dibbell and Tajima techniques: a 10-year review. Plastic and Reconstructive Surgery. 124(6), 2041-2047.

66. Foda, H. M. and Bassyouni, K. 2000. Rhinoplasty in unilateral cleft lip nasal deformity. The Journal of Laryngology and Otology. 114(3), 189-193.

67. Freeman, A. K., Mercer, N. S. G. and Roberts, L. M. 2013. Nasal asymmetry in unilateral cleft lip and palate. Journal of Plastic, Reconstructive \& Aesthetic Surgery. 66(4), 506-512.

68. Fudalej, P., Katsaros, C., Bongaarts, C., Dudkiewicz, Z. and Kuijpers-Jagtman, A. M. 2009. Nasolabial esthetics in children with complete unilateral cleft lip and palate after 1-versus 3-stage treatment protocols. Journal of Oral and Maxillofacial Surgery. 67(8), 1661-1666.

69. Fudalej, P., Katsaros, C., Hozyasz, K., Borstlap, W. A. and Kuijpers-Jagtman, A. M. 2012. Nasolabial symmetry and aesthetics in children with complete unilateral cleft lip and palate. The British Journal of Oral \& Maxillofacial Surgery. 50(7), 621-625.

70. Fukushiro, A. P. and Trindade, I. E. K. 2005. Nasal airway dimensions of adults with cleft lip and palate: differences among cleft types. The Cleft Palate-Craniofacial Journal. 42, 396-402.

71. Gassling, V., Koos, B., Birkenfeld, F., Wiltfang, J. and Zimmermann, C. E. 2015. Secondary cleft nose rhinoplasty: Subjective and objective outcome evaluation. Journal of Cranio-Maxillofacial Surgery. 43(9), 1855-1862.

72. Gosain, A. K. and Fathi, A. H. 2009. Assessment of secondary cleft rhinoplasty using resorbable plates at the age of primary school. The Journal of Craniofacial Surgery. 20(2), 1801-1805.

73. Grayson, B. H. and Cutting, C. B. 2001. Presurgical Nasoalveolar Orthopedic Molding in Primary Correction of the Nose, Lip, and Alveolus of Infants Born With Unilateral and Bilateral Clefts. The Cleft Palate-Craniofacial Journal. 38(3), 193-198.

74. Grayson, B. H., Santiago, P. E., Brecht, L. E. and Cutting, C. B. 1999. Presurgical Nasoalveolar Molding in Infants with Cleft Lip and Palate. The Cleft Palate-Craniofacial Journal. 36(6), 486-498.

75. Gubisch, W. 1995. Functional and aesthetic nasal reconstruction in unilateral CLP-deformity. Facial Plastic Surgery: FPS. 11, 159-168.

76. Guyuron, B. 2008. MOC-PS(SM) CME article: late cleft lip nasal deformity. Plastic and Reconstructive Surgery. 121, 1-11.

77. Gurley, J. M., Pilgram, T., Perlyn, C. A. and Marsh, J. L. 2001. Long-term outcome of autogenous rib graft nasal reconstruction. Plastic and Reconstructive Surgery. 108, 1895-1907.

78. Hafezi, F., Naghibzadeh, B., Ashtiani, A. K., Mousavi, S. J., Nouhi, A. H. and Naghibzadeh, G. 2013. Correction of cleft lip nose deformity with rib cartilage. Aesthetic Surgery Journal / the American Society for Aesthetic Plastic Surgery. 33(5), 662-673.

79. He, X., Li, H., Shao, Y. and Shi, B. 2015. Objective measurements for grading the nasal esthetics on Basal view in individuals with secondary cleft nasal deformity. The Cleft Palate-Craniofacial Journal. 52(1), 66-69.

80. He, X., Shi, B., Kamdar, M., Zheng, Q., Li, S. and Wang, Y. 2009a. Development of a method for rating nasal appearance after cleft lip repair. Journal of Plastic, Reconstructive \& Aesthetic Surgery. 62(11), 1437-1441. 
81. He, Z. J., Jian, X., Wu, X., Gao, X., Zhou, S. and Zhong, X. 2009b. Anthropometric measurement and analysis of the external nasal soft tissue in 119 young Han Chinese adults. The Journal of Craniofacial Surgery. 20, 1347-1351.

82. van der Heijden, P., Dijkstra, P. U., Stellingsma, C., van der Laan, B. F., Korsten-Meijer, A. G. W. and Goorhuis-Brouwer, S. M. 2013. Limited Evidence for the Effect of Presurgical Nasoalveolar Molding in Unilateral Cleft on Nasal Symmetry. Plastic and Reconstructive Surgery. 131(1), 62-71.

83. Hood, C. A., Bock, M., Hosey, M. T., Bowman, A. and Ayoub, A. F. 2003. Facial asymmetry-3D assessment of infants with cleft lip \& palate. International Journal of Paediatric Dentistry. $13,404-410$.

84. Hood, C. A., Hosey, M. T., Bock, M., White, J., Ray, A. and Ayoub, A. F. 2004. Facial characterization of infants with cleft lip and palate using a three-dimensional capture technique.

The Cleft Palate-Craniofacial Journal. 41(1), 27-35.

85. Huempfner-Hierl, H., Hemprich, A. and Hierl, T. 2009. Results of a prospective anthropometric and functional study about aesthetics and nasal respiration after secondary rhinoplasty in cleft lip and palate patients. The Journal of Craniofacial Surgery. 20(2), 1863-1875.

86. Hurwitz, D. J., Ashby, E. R., Llull, R., Pasqual, J., Tabor, C., Garrison, L., Gillen, J. and Weyant, R. 1999. Computer-assisted anthropometry for outcome assessment of cleft lip. Plastic and Reconstructive Surgery. 103(6), 1608-1623.

87. Iliopoulos, C., Mitsimponas, K., Lazaridou, D., Neukam, F. W. and Stelzle, F. 2014. A retrospective evaluation of the aesthetics of the nasolabial complex after unilateral cleft lip repair using the Tennison-Randall technique: a study of 44 cases treated in a single cleft center. Journal of Cranio-Maxillo-Facial Surgery. 42(8), 1679-1683.

88. Isogawa, N., Ochiai, S., Mito, T., Kindaichi, J., Ishibashi, N., Takagi, Y. and Ishikawa, M. 2010. Three-Dimensional Comparison in Palatal Forms Between Modified Presurgical Nasoalveolar Molding Plate and Hotz's Plate Applied to the Infants With Unilateral Cleft Lip and Palate. Singapore Dental Journal. 31(1), 36-42.

89. Jones, L. R. and Tatum, S. A. 2008. Pearls for aesthetic reconstruction of cleft lip and nose defects. Facial Plastic Surgery. 24(1), 146-151.

90. Kaiser, G. L., Jost, A., Scheurer, T. and Thüer, U. 1996. Lip repair according to the principles of Delaire. What is its significance? European Journal of Pediatric Surgery. 6(1), 3-6.

91. Kane, A. A., Pilgram, T. K., Moshiri, M. and Marsh, J. L. 2000. Long-term outcome of cleft lip nasal reconstruction in childhood. Plastic and Reconstructive Surgery. 105(5), 1600-1608.

92. Karube, R., Sasaki, H., Togashi, S., Yanagawa, T., Nakane, S., Ishibashi, N., Yamagata, K., Onizawa, K., Adachi, K., Tabuchi, K., Sekido, M. and Bukawa, H. 2012. A novel method for evaluating postsurgical results of unilateral cleft lip and palate with the use of Hausdorff distance: presurgical orthopedic treatment improves nasal symmetry after primary cheiloplasty. Oral Surgery, Oral Medicine, Oral Pathology and Oral Radiology. 114(6), 704-711.

93. Keijser, K., Nowinski, D. and Mani, M. 2016. Photographic Measurements Partially Correlate to Nasal Function and Appearance among Adult Cleft Patients. Plastic and Reconstructive Surgery. 4(5), 720.

94. Kim, J. B., Strike, P. and Cadier, M. C. 2011. A simple assessment method for auditing multicentre unilateral cleft lip repairs. Journal of Plastic, Reconstructive and Aesthetic Surgery. 64, 195-200.

95. Kim, S. K., Cha, B. H., Lee, K. C. and Park, J. M. 2004. Primary correction of unilateral cleft lip nasal deformity in Asian patients: anthropometric evaluation. Plastic and Reconstructive Surgery. 114(6), 1373-1381.

96. Kim, S. C., Nam, K. C., Rah, D. K., Cha, E. J. and Kim, D. W. 2009. Assessment of the cleft nasal deformity using a regression equation. The Cleft Palate-Craniofacial Journal. 46(2), $197-$ 203.

97. Kim, S. K., Heo, G. E., Seo, A., Na, Y. and Chung, S. K. 2014. Correlation between nasal airflow characteristics and clinical relevance of nasal septal deviation to nasal airway obstruction. Respiratory Physiology \& Neurobiology. 192, 95-101. 
98. Kyrkanides, S., Bellohusen, R. and Subtelny, J. D. 1996. Asymmetries of the upper lip and nose in noncleft and postsurgical unilateral cleft lip and palate individuals. The Cleft PalateCraniofacial Journal. 33(4), 306-311.

99. Koh, K. S. and Kim, E. K. 2006. Management of unilateral cleft lip nose deformity, with retracted ala of the noncleft side. Plastic and Reconstructive Surgery. 118(3), 723-729.

100. Krasone, K., Lace, B., Akota, I., Care, R., Deeley, K., Küchler, E. C. and Vieira, A. R. 2014. IRF6 AP-2a binding site promoter polymorphism is associated with oral clefts in Latvia. Stomatologija. 16(4), 132-136.

101. Kuijpers-Jagtman, A. M., Nollet, P. J. P. M., Semb, G., Bronkhorst, E. M., Shaw, W. C. and Katsaros, C. 2009. Reference photographs for nasolabial appearance rating in unilateral cleft lip and palate. The Journal of Craniofacial Surgery. 20(2), 1683-1686.

102. Kunkel, M., Wahlmann, U. and Wagner, W. 1997. Nasal airway in cleft-palate patients: acoustic rhinometric data. Journal of Cranio-Maxillo-Facial Surgery. 25(5), 270-274.

103. Landis, J. R. and Koch, G. G. 1977. An application of hierarchical kappa-type statistics in the assessment of majority agreement among multiple observers. Biometrics. 33(2), 363-374.

104. Li, C., Shi, B., He, X. and Meng, T. 2010. Evaluation of facial growth in non-cleft patients using the analysis method for patients after a cleft lip and/or palate repair. Journal of Plastic, Reconstructive \& Aesthetic Surgery. 63(2), 277-281.

105. Li, J., Shi, B., Liu, K. and Zheng, Q. 2012. A preliminary study on the hard-soft tissue relationships among unoperated secondary unilateral cleft nose deformities. Oral Surgery, Oral Medicine, Oral Pathology and Oral Radiology. 113(3), 300-307.

106. Li, J., Shi, B., Liu, K., Zheng, Q., Wang, Y. and Li, S. 2011. A photogrammetric study of the effects of alveolar bone graft on nose symmetry among unilateral cleft patients. Journal of Plastic, Reconstructive \& Aesthetic Surgery. 64(11), 1436-1443.

107. Liou, E. J. W., Subramanian, M., Chen, P. K. T. and Huang, C. S. 2004. The progressive changes of nasal symmetry and growth after nasoalveolar molding: a three-year follow-up study. Plastic and Reconstructive Surgery. 114(4), 858-864.

108. Lo, L. J., Wong, F. H., Mardini, S., Chen, Y. R. and Noordhoff, M. S. 2002. Assessment of bilateral cleft lip nose deformity: a comparison of results as judged by cleft surgeons and laypersons. Plastic and Reconstructive Surgery. 110, 733-741.

109. Lonic, D., Morris, D. E. and Lo, L. J. 2016. Primary Overcorrection of the Unilateral Cleft Nasal Deformity: Quantifying the Results. Annals of Plastic Surgery. 77(1) 25-29.

110. van Loon, B., Maal, T. J., Plooij, J. M., Ingels, K. J., Borstlap, W. A., Kuijpers-Jagtman, A. M., Spauwen, P. H. and Bergé, S. J. 2010. 3D Stereophotogrammetric assessment of pre- and postoperative volumetric changes in the cleft lip and palate nose. International Journal of Oral and Maxillofacial Surgery. 39(6), 534-540.

111. Lorot-Marchand, A., Guerreschi, P., Pellerin, P., Martinot, V., Gbaguidi, C. C., Neiva, C., Devauchelle, B., Frochisse, C., Poli-Merol, M. L. and Francois-Fiquet, C. 2015. Frequency and socio-psychological impact of taunting in school-age patients with cleft lip-palate surgical repair. International Journal of Pediatric Otorhinolaryngology. 79(7), 1041-1048.

112. Lu, K. H. 1965. Harmonic analysis of the human face. Biometrics. 21, 491-505.

113. Luyten, A., D'haeseleer, E., Budolfsen, D., Hodges, A., Galiwango, G., Vermeersch, H. and Van Lierde, K. 2013. Parental satisfaction in Ugandan children with cleft lip and palate following synchronous lip and palatal repair. Journal of Communication Disorders. 46(4), 321-329.

114. Mani, M., Morén, S., Thorvardsson, O., Jakobsson, O., Skoog, V. and Holmström, M. 2010. EDITOR'S CHOICE: objective assessment of the nasal airway in unilateral cleft lip and palate-a long-term study. The Cleft Palate-Craniofacial Journal. 47(3), 217-224.

115. Manosudprasit, M., Wangsrimongkol, T., Pisek, P. and Wiwatworakul, O. 2014. Pre-surgical nasoalveolar molding technique: a literature review. Journal of the Medical Association of Thailand. 97(1) 17-24.

116. Matsuya, T., Iida, S. and Kogo, M. 2003. Secondary rhinoplasty using flying-bird and vestibular tornado incisions for unilateral cleft lip patients. Plastic and Reconstructive Surgery. 112(2), 390-395.

117. Matsuo, K. and Hirose, T. 1991. Preoperative non-surgical over-correction of cleft lip nasal deformity. British Journal of Plastic Surgery. 44(1), 5-11. 
118. Maulina, I., Priede, D., Linkeviciene, L. and Akota, I. 2007. The influence of early orthodontic treatment on the growth of craniofacial complex in deciduous occlusion of unilateral cleft lip and palate patients. Stomatologija. 9(3), 91-96.

119. Maull, D. J., Grayson, B. H., Cutting, C. B., Brecht, L. L., Bookstein, F. L., Khorrambadi, D., Webb, J. A. and Hurwitz, D. J. 1999. Long-term effects of nasoalveolar molding on threedimensional nasal shape in unilateral clefts. The Cleft Palate-Craniofacial Journal. 36(5), 391397.

120. McComb, H. K. and Coghlan, B. A. 1996. Primary repair of the unilateral cleft lip nose: completion of a longitudinal study. The Cleft Palate-Craniofacial Journal. 33(1), 23-31.

121. McKearney, R. M., Williams, J. V. and Mercer, N. S. 2013. Quantitative computer-based assessment of lip symmetry following cleft lip repair. The Cleft Palate-Craniofacial Journal. 50(2), 138-143.

122. Meazzini, M. C., Rossetti, G., Morabito, A., Garattini, G. and Brusati, R. 2010. Photometric evaluation of bilateral cleft lip and palate patients after primary columella lengthening. The Cleft Palate-Craniofacial Journal. 47(1), 58-65.

123. Meng, T., Ma, L. and Wang, Z. 2015. Comparative Assessment of the Cleft Profile by Patients with Cleft Lip and Palate, Cleft Surgeons, and Lay People. Aesthetic Plastic Surgery. 39(5), 757763.

124. Mercado, A. M., Russell, K. A., Daskalogiannakis, J., Hathaway, R. R., Semb, G., Ozawa, T., Smith, A., Lin, A. Y. and Long, R. E. Jr. 2016. The americleft project: A proposed expanded nasolabial appearance yardstick for 5-to 7-year-old patients with complete unilateral cleft lip and palate (CUCLP). The Cleft Palate-Craniofacial Journal. 53(1), 30-37.

125. Mercado, A., Russell, K., Hathaway, R., Daskalogiannakis, J., Sadek, H., Long, R. E. Jr., Cohen, M., Semb, G. and Shaw, W. 2011. The americleft study: an inter-center study of treatment outcomes for patients with unilateral cleft lip and palate part 4. Nasolabial aesthetics. The Cleft Palate-Craniofacial Journal. 48, 259-264.

126. Millard, D. R. Jr. 1976. Cleft Craft: The Evolution of Its Surgery-Volume I: The Unilateral Deformity. Boston: Little Brown and Company.

127. Miyamoto, J., Miyamoto, S., Nagasao, T., Nakajima, T. and Kishi, K. 2012. Anthropometric evaluation of bilateral cleft lip nose with cone beam computed tomography in early childhood: Estimation of nasal tip collapse. Journal of Plastic, Reconstructive and Aesthetic Surgery. 65(2), 169-174.

128. Miyamoto, J. and Nakajima, T. 2010. Anthropometric evaluation of complete unilateral cleft lip nose with cone beam CT in early childhood. Journal of Plastic, Reconstructive and Aesthetic Surgery. 63(1), 9-14.

129. Mishima, K., Mori, Y., Yamada, T. and Sugahara, T. 2002. Anthropometric analysis of the nose in the Japanese. Cells, Tissues, Organs. 170(2-3), 198-206.

130. Mølsted, K., Humerinta, K., Küseler, A., Skaare, P., Bellardie, H., Shaw, W., Karsten, A., Kåre Sæle, P., Rizell, S., Marcusson, A., Eyres, P. and Semb, G. 2017. Scandcleft randomised trials of primary surgery for unilateral cleft lip and palate: 8 . Assessing naso-labial appearance in 5-yearolds - a preliminary study. Journal of Plastic Surgery and Hand Surgery. 51(1), 64-72.

131. Mommaerts, M. Y. and Nagy, K. 2008. Analysis of the cleft lip-nose in the submental-vertical view. Part II. Panel study: which is the most important deformity? Journal of Cranio-MaxilloFacial Surgery. 36, 315-320.

132. Mori, A., Nakajima, T., Kaneko, T., Sakuma, H. and Aoki, Y. 2005. Analysis of 109 Japanese children's lip and nose shapes using 3-dimensional digitizer. British Journal of Plastic Surgery. 58(3), 318-329.

133. Morrant, D. G. and Shaw, W. C. 1996. Use of standardized video recordings to assess cleft surgery outcome. The Cleft Palate-Craniofacial Journal. 33(2), 134-142.

134. Mosmuller, D. G. M., Bijnen, C. L., Don Griot, J. P. W., Kramer, G. J. C., Disse, M. A., Prahl, C., Kuik, D. J. and Niessen, F. B. 2014. Comparison of two scoring systems in the assessment of nasolabial appearance in cleft lip and palate patients. The Journal of Craniofacial Surgery. 25(4), 1222-1225.

135. Mosmuller, D. G. M., Mennes, L. M., Prahl, C., Kramer, G. J. C., Disse, M. A., van Couwelaar, G. M., Niessen, F. B. and Griot, J. P. W. D. 2016b. The Development of the Cleft Aesthetic Rating Scale: A New Rating Scale for the Assessment of Nasolabial Appearance in Complete Unilateral Cleft Lip and Palate Patients. The Cleft Palate-Craniofacial Journal. 555-561. 
136. Mosmuller, D. G. M., Tan, R., Mulder, F., Bachour, Y., de Vet, H. and Don Griot, P. 2016a. The use and reliability of SymNose for quantitative measurement of the nose and lip in unilateral cleft lip and palate patients. Journal of Cranio-Maxillo-Facial Surgery. 44(10), $1515-1521$.

137. Mulliken, J. B. and Martínez-Pérez, D. 1999. The principle of rotation advancement for repair of unilateral complete cleft lip and nasal deformity: technical variations and analysis of results. Plastic and Reconstructive Surgery. 104, 1247-1260.

138. Nagasao, T., Miyamoto, J., Yasuda, S., Ogata, H., Imanishi, Y., Zhu, X., Jiang, H., Ogawa, K. and Nakajima, T. 2008. An anatomical study of the three-dimensional structure of the nasal septum in patients with alveolar clefts and alveolar-palatal clefts. Plastic and Reconstructive Surgery. 121(6), 2074-2083.

139. Nagy, K. and Mommaerts, M. Y. 2007. Analysis of the cleft-lip nose in submental-vertical view, Part I--reliability of a new measurement instrument. Journal of Cranio-Maxillo-Facial Surgery. 35(6-7), 265-277.

140. Nakamura, N., Okawachi, T., Nishihara, K., Hirahara, N. and Nozoe, E. 2010. Surgical technique for secondary correction of unilateral cleft lip-nose deformity: clinical and 3-dimensional observations of preoperative and postoperative nasal forms. Journal of Oral and Maxillofacial Surgery. 68(9), 2248-2257.

141. Nollet, P. J. P. M., Kuijpers-Jagtman, A. M., Chatzigianni, A., Semb, G., Shaw, W. C., Bronkhorst, E. M. and Katsaros, C. 2007. Nasolabial appearance in unilateral cleft lip, alveolus and palate: a comparison with Eurocleft. Journal of Cranio-Maxillo-Facial Surgery. 35(6-7), 278-286.

142. Nolst Trenité, G. J. 2002. Secondary rhinoplasty in the bilateral cleft. Facial Plastic Surgery: FPS. 18(3), 179-186.

143. Nolst Trenité, G. J. 2006. Secondary rhinoplasty in the cleft lip patient. B-ENT. 2(4), 102-108.

144. Nolst Trenité, G. J., Paping, R. H. and Trenning, A. H. 1997. Rhinoplasty in the cleft lip patient. The Cleft Palate-Craniofacial Journal. 34, 63-68.

145. Noor, S. N. F. M. and Musa, S. 2007. Assessment of patients' level of satisfaction with cleft treatment using the Cleft Evaluation Profile. The Cleft Palate-Craniofacial Journal. 44, 292-303.

146. Offert, B., Janiszewska-Olszowska, J., Dudkiewicz, Z., Brudnicki, A., Katsaros, C. and Fudalej, P. S. 2013. Facial esthetics in children with unilateral cleft lip and palate 3 years after alveolar bonegrafting combined with rhinoplasty between 2 and 4 years of age. Orthodontics \& Craniofacial Research. 16(1), 36-43.

147. Ohannessian, P., Berggren, A. and Abdiu, A. 2011. The cleft lip evaluation profile (CLEP): a new approach for postoperative nasolabial assessment in patients with unilateral cleft lip and palate. Journal of Plastic Surgery and Hand Surgery. 45(1), 8-13.

148. Okawachi, T., Nozoe, E., Nishihara, K. and Nakamura, N. 2011. 3-Dimensional Analyses of Outcomes Following Secondary Treatment of Unilateral Cleft Lip Nose Deformity. Journal of Oral and Maxillofacial Surgery. 69(2), 322-332.

149. Oosterkamp, B. C. M., Dijkstra, P. U., Remmelink, H. J., van Oort, R. P., Goorhuis-Brouwer, S. M., Sandham, A. and de Bont, L. G. M. 2007. Satisfaction with treatment outcome in bilateral cleft lip and palate patients. International Journal of Oral and Maxillofacial Surgery. 36, 890-895.

150. Othman, S. A., Ahmad, R., Asi, S. M., Ismail, N. H. and Rahman, Z. A. A. 2014. Threedimensional quantitative evaluation of facial morphology in adults with unilateral cleft lip and palate, and patients without clefts. The British Journal of Oral \& Maxillofacial Surgery. 52(3), 208-213.

151. Oti, A. A., Obiri-Yeboah, S. and Donkor, P. 2014. Aesthetic outcome and the need for revision of unilateral cleft lip repair at Komfo Anokye Teaching Hospital. Ghana Medical Journal. 48(1), 20-23.

152. Pai, B. C. J., Ko, E. W. C., Huang, C. S. and Liou, E. J. W. 2005. Symmetry of the nose after presurgical nasoalveolar molding in infants with unilateral cleft lip and palate: a preliminary study. The Cleft Palate-Craniofacial Journal. 42(6), 658-663.

153. Paiva, T. S., Andre, M., Paiva, W. S. and Mattos, B. S. C. 2014. Aesthetic evaluation of the nasolabial region in children with unilateral cleft lip and palate comparing expert versus nonexperience health professionals. BioMed Research International. 2014, 460106. 
154. Papamanou, D. A., Gkantidis, N., Topouzelis, N. and Christou, P. 2012. Appreciation of cleft lip and palate treatment outcome by professionals and laypeople. European Journal of Orthodontics. 34(5), 553-560.

155. Peck, H. and Peck, S. 1970. A concept of facial esthetics. Angle Orthodontist. 40(4), 284-318.

156. Peterka, M., Peterková, R., Tvrdek, M., Kuderová, J. and Likovský, Z. 2000. Significant differences in the incidence of orofacial clefts in fifty-two Czech districts between 1983 and 1997. Acta Chirurgiae Plasticae. 42, 124-129.

157. Pietruski, P., Majak, M., Pawlowska, E., Skiba, A. and Antoszewski, B. 2017. A novel computer system for the evaluation of nasolabial morphology, symmetry and aesthetics after cleft lip and palate treatment. Part 2: Comparative anthropometric analysis of patients with repaired unilateral complete cleft lip and palate and healthy i. Journal of Cranio-Maxillo-Facial Surgery. 45(4), 505-514.

158. Pigott, R. W. and Pigott, B. B. 2010. Quantitative measurement of symmetry from photographs following surgery for unilateral cleft lip and palate. The Cleft Palate-Craniofacial Journal. 47(4), 363-367.

159. Pitak-Arnnop, P., Hemprich, A., Dhanuthai, K., Yildirim, V. and Pausch, N. C. 2011. Panel and patient perceptions of nasal aesthetics after secondary cleft rhinoplasty with versus without columellar grafting. Journal of Cranio-Maxillo-Facial Surgery. 39(5), 319-325.

160. Reddy, G. S., Webb, R. M., Reddy, R. R., Reddy, L. V, Thomas, P. and Markus, A. F. 2008. Choice of incision for primary repair of unilateral complete cleft lip: a comparative study of outcomes in 796 patients. Plastic and Reconstructive Surgery. 121, 932-940.

161. Reddy, S. G., Devarakonda, V. and Reddy, R. R. 2013. Assessment of nostril symmetry after primary cleft rhinoplasty in patients with complete unilateral cleft lip and palate. Journal of Cranio-Maxillo-Facial Surgery. 41(2), 147-152.

162. Reiser, E., Andlin-Sobocki, A., Mani, M. and Holmström, M. 2011. Initial size of cleft does not correlate with size and function of nasal airway in adults with unilateral cleft lip and palate. Journal of Plastic Surgery and Hand Surgery. 45(3), 129-135.

163. Ridgway, E. B., Andrews, B. T., Labrie, R. A., Padwa, B. L. and Mulliken, J. B. 2011. Positioning the caudal septum during primary repair of unilateral cleft lip. The Journal of Craniofacial Surgery. 22, 1219-1224.

164. Roosenboom, J., Hellings, P. W., Picavet, V. A., Prokopakis, E. P., Antonis, Y., Schoenaers, J., Vander Poorten, V., Claes, P. and Hens, G. 2014. Secondary cleft rhinoplasty: impact on selfesteem and quality of life. Plastic and Reconstructive Surgery. 134(6), 1285-1292.

165. Rossell-Perry, P. and Gavino-Gutierrez, A. M. 2011. Upper Double-Rotation Advancement Method for Unilateral Cleft Lip Repair of Severe Forms. Journal of Craniofacial Surgery. 22, 2036-2042.

166. Rubin, M. S., Clouston, S., Ahmed, M. M., Lowe, K., Shetye, P. R., Broder, H. L., Warren, S. M. and Grayson, B. H. 2015. Assessment of presurgical clefts and predicted surgical outcome in patients treated with and without nasoalveolar molding. The Journal of Craniofacial Surgery. 26(1), 71-75.

167. Russell, J. H. B., Kiddy, H. C. and Mercer, N. S. 2014. The use of SymNose for quantitative assessment of lip symmetry following repair of complete bilateral cleft lip and palate. Journal of Cranio-Maxillo-Facial Surgery. 42(5), 454-459.

168. Russell, K. A., Milne, A. D., Varma, D., Josephson, K. and Lee, J. M. 2011. Three-dimensional morphologic nasal surface characteristics that predict the extremes of esthetics in patients with repaired cleft lip and palate. The Cleft Palate-Craniofacial Journal. 48(1), 28-37.

169. Russell, K. A., Waldman, S. D. and Lee, J. M. 2000. Video-imaging assessment of nasal morphology in individuals with complete unilateral cleft lip and palate. The Cleft PalateCraniofacial Journal. 37(6), 542-550.

170. Russell, K. A., Waldman, S. D., Tompson, B. and Lee, J. M. 2001. Nasal morphology and shape parameters as predictors of nasal esthetics in individuals with complete unilateral cleft lip and palate. The Cleft Palate-Craniofacial Journal. 38(5), 476-485.

171. Russell, K., Orthod, D., Tompson, B. and Paedo, D. 2009. Correlation between facial morphology and esthetics in patients with repaired complete unilateral cleft lip and palate. The Cleft PalateCraniofacial Journal. 46(3), 319-325.

172. Salyer, K. E. 1992. Early and Late Treatment of Unilateral Cleft Nasal Deformity. The Cleft Palate-Craniofacial Journal. 29(6), 556-569. 
173. Sandham, A. and Murray, J. A. 1993. Nasal septal deformity in unilateral cleft lip and palate. The Cleft Palate-Craniofacial Journal. 30, 222-226.

174. Scopelliti, D., Fatone, F. M. G., Cipriani, O. and Papi, P. 2013. Simultaneous options for cleft secondary deformities. Annals of Maxillofacial Surgery. 3(2), 173-177.

175. Shaw, W. C., Semb, G., Nelson, P., Brattstrom, V., Molsted, K., Prahl-Andersen, B. and Gundlach, K. K. H. 2001. The Eurocleft Project 1996-2000: overview. Journal of CranioMaxillofacial Surgery. 29(3), 131-140.

176. Shih, C. W. and Sykes, J. M. 2002. Correction of the Cleft-Lip Nasal Deformity. Facial Plastic Surgery. 18(4), 253-262.

177. Singh, G. D., Levy-Bercowski, D. and Santiago, P. E. 2005. Three-dimensional nasal changes following nasoalveolar molding in patients with unilateral cleft lip and palate: geometric morphometrics. The Cleft Palate-Craniofacial Journal. 42(4), 403-409.

178. Sinko, K., Jagsch, R., Prechtl, V., Watzinger, F., Hollmann, K. and Baumann, A. 2005. Evaluation of esthetic, functional, and quality-of-life outcome in adult cleft lip and palate patients. The Cleft Palate-Craniofacial Journal. 42(4), 355-361.

179. Sischo, L., Broder, H. L. and Phillips, C. 2015. Coping With Cleft: A Conceptual Framework of Caregiver Responses to Nasoalveolar Molding. The Cleft Palate-Craniofacial Journal. 52(6), 640-650.

180. Sitzman, T. J., Mara, C. A., Long, R. E., Daskalogiannakis, J., Russell, K. A., Mercado, A. M., Hathaway, R. R., Carle, A. C., Semb, G. and Shaw, W. C. 2015. The Americleft Project: Burden of care from secondary surgery. Plastic and Reconstructive Surgery Glob Open. 3(7), e442.

181. Smahel, Z. and Müllerova, Z. 1996. Postpubertal growth and development of the face in unilateral cleft lip and palate as compared to the pubertal period: a longitudinal study. Journal of Craniofacial Genetics and Developmental Biology. 16(3), 182-192.

182. Smolka, K., Eggernsperger, N., Iizuka, T. and Smolka, W. 2008. Evaluation of secondary functional cheilorhinoplasty during growth of cleft patients with residual lip and nasal deformities. Journal of Oral and Maxillofacial Surgery. 66(12), 2577-2584.

183. Stauber, I., Vairaktaris, E., Holst, A., Schuster, M., Hirschfelder, U., Neukam, F. W. and Nkenke, E. 2008. Three-dimensional analysis of facial symmetry in cleft lip and palate patients using optical surface data. Journal of Orofacial Orthopedics. 69(4), 268-282.

184. Stebel, A., Desmedt, D., Bronkhorst, E., Kuijpers, M. A. and Fudalej, P. S. 2016. Rating nasolabial appearance on three-dimensional images in cleft lip and palate: a comparison with standard photographs. European Journal of Orthodontics. 38(2), 197-201.

185. Sugihara, T., Yoshida, T., Igawa, H. H. and Homma, K. 1993. Primary correction of the unilateral cleft lip nose. The Cleft Palate-Craniofacial Journal. 30(2), 231-236.

186. Suri, S., Utreja, A., Khandelwal, N. and Mago, S. K. 2008. Craniofacial computerized tomography analysis of the midface of patients with repaired complete unilateral cleft lip and palate. American Journal of Orthodontics and Dentofacial Orthopedics. 134(3), 418-429.

187. Tang, P. M. Y., Chao, N. S. Y., Leung, M. W. Y. and Kelvin, K. W. L. 2016. Changes in Nasal Configuration Following Primary Rhinoplasty: Direct Anthropometric Measurement in Patients With Complete Unilateral Cleft Lip and Palate. The Cleft Palate-Craniofacial Journal. 53(5), 557-561.

188. Tanikawa, D. Y. S., Alonso, N. and Rocha, D. L. 2010. Evaluation of primary cleft nose repair: severity of the cleft versus final position of the nose. The Journal of Craniofacial Surgery. 21, 1519-1524.

189. Thomas, C. and Mishra, P. 2000. Open tip rhinoplasty along with the repair of cleft lip in cleft lip and palate cases. British Journal of Plastic Surgery. 53(1), 1-6.

190. Timoney, N., Smith, G. and Pigott, R. W. 2001. A 20 year audit of nose-tip symmetry in patients with unilateral cleft lip and palate. British Journal of Plastic Surgery. 54, 294-298.

191. Tindlund, R. S., Holmefjord, A., Eriksson, J. C. H., Johnson, G. E. and Vindenes, H. 2009. Interdisciplinary evaluation of consecutive patients with unilateral cleft lip and palate at age 6 , 15, and 25 years: a concurrent standardized procedure and documentation by plastic surgeon; speech and language pathologist; ear, nose, and throat speciali. The Journal of Craniofacial Surgery. 20(2), 1687-1698.

192. Torre, J. I., Gallagher, P. M., Douglas, B. K. and Tenenhaus, M. 2000. Repairing the Cleft Lip Nasal Deformity. The Cleft Palate-Craniofacial Journal. 37(3), 234-242. 
193. Trindade, I. E. K., Bertier, C. E. and Sampaio-Teixeira, A. C. M. 2009. Objective assessment of internal nasal dimensions and speech resonance in individuals with repaired unilateral cleft lip and palate after rhinoseptoplasty. The Journal of Craniofacial Surgery. 20(2), 308-314.

194. Trotman, C. A., Faraway, J. J., Losken, H. W. and van Aalst, J. A. 2007. Functional outcomes of cleft lip surgery. Part II: Quantification of nasolabial movement. The Cleft Palate-Craniofacial Journal. 44(6), 607-616.

195. Tse, R., Booth, L., Keys, K., Saltzman, B., Stuhaug, E., Kapadia, H. and Heike, C. 2014. Reliability of nasolabial anthropometric measures using three-dimensional stereophotogrammetry in infants with unrepaired unilateral cleft lip. Plastic and Reconstructive Surgery. 133(4), 530-542.

196. Tse, R. W., Oh, E., Gruss, J. S., Hopper, R. A. and Birgfeld, C. B. 2016. Crowdsourcing as a Novel Method to Evaluate Aesthetic Outcomes of Treatment for Unilateral Cleft Lip. Plastic and Reconstructive Surgery. 138(4), 864-874.

197. Vegter, F., Mulder, J. W. and Hage, J. J. 1997. Major residual deformities in cleft patients: a new anthropometric approach. The Cleft Palate-Craniofacial Journal. 34(2), 106-110.

198. Verzé, L., Bianchi, F. A. and Ramieri, G. 2014. Three-dimensional laser scanner evaluation of facial soft tissue changes after LeFort I advancement and rhinoplasty surgery: patients with cleft lip and palate vs patients with nonclefted maxillary retrognathic dysplasia (control group). Oral Surgery, Oral Medicine, Oral Pathology and Oral Radiology. 117(4), 416-423.

199. Weinberg, S. M., Naidoo, S. D., Bardi, K. M., Brandon, C. A, Neiswanger, K., Resick, J. M., Martin, R. A. and Marazita, M. L. 2009. Face shape of unaffected parents with cleft affected offspring: combining three-dimensional surface imaging and geometric morphometrics. Orthodontics \& Craniofacial Research. 12(4), 271-281.

200. Wong, G. B., Burvin, R. and Mulliken, J. B. 2002. Resorbable internal splint: an adjunct to primary correction of unilateral cleft lip-nasal deformity. Plastic and Reconstructive Surgery. 110(2), 385-391.

201. Wu, J., Heike, C., Birgfeld, C., Evans, K., Maga, M., Morrison, C., Saltzman, B., Shapiro, L. and Tse, R. 2016a. Measuring Symmetry in Children With Unrepaired Cleft Lip: Defining a Standard for the Three-Dimensional Midfacial Reference Plane. The Cleft Palate-Craniofacial Journal. 53(6), 695-704.

202. Wu, J., Liang, S., Shapiro, L. and Tse, R. 2016b. Measuring Symmetry in Children With Cleft Lip. Part 2: Quantification of Nasolabial Symmetry Before and After Cleft Lip Repair. The Cleft Palate-Craniofacial Journal. 53(6), 705-713.

203. Yamada, T., Mori, Y., Minami, K., Mishima, K., Sugahara, T. and Sakuda, M. 1999. Computer aided three-dimensional analysis of nostril forms: application in normal and operated cleft lip patients. Journal of Cranio-Maxillo-Facial Surgery. 27, 345-353.

204. Yamada, T., Mori, Y., Minami, K., Mishima, K. and Tsukamoto, Y. 2002. Surgical results of primary lip repair using the triangular flap method for the treatment of complete unilateral cleft lip and palate: a three-dimensional study in infants to four-year-old children. The Cleft PalateCraniofacial Journal. 39(5), 497-502.

205. Yoon, Y. J., Perkiomaki, M. R., Tallents, R. H., Barillas, I., Herrera-Guido, R., Fong, C. T. and Kyrkanides, S. 2003. Association of nasomaxillary asymmetry in children with unilateral cleft lip and palate and their parents. The Cleft Palate-Craniofacial Journal. 40(5), 493-497.

206. Zaleckas, L., Linkevičiene, L., Olekas, J. and Kutra, N. 2011. The Comparison of Different Surgical Techniques Used for Repair of Complete Unilateral Cleft Lip. Medicina (Kaunas). 47(2), $85-90$.

207. Zreaqat, M., Hassan, R. and Halim, A. S. 2012. Facial dimensions of Malay children with repaired unilateral cleft lip and palate: a three dimensional analysis. International Journal of Oral and Maxillofacial Surgery. 41(6), 783-788.

208. Баркане, Б. Я. 1968. Оперативное лечение деформаций губы и носа при врожденных расщелинах лица: Диссертация на соискание учен. степени канд. мед. наук. Рига. 328 с. 


\section{PUBLIKĀCIJAS UN ZIŅOJUMI PAR PĒTĪJUMA TĒMU}

\section{Publikācijas starptautiski citējamos zinātniskos izdevumos}

1. Bagante, I. and Akota, I. 2015. Cleft-related nose deformation evaluation and measurement methods. Literature review. Stomatologija. 17(3), 75-83.

2. Bagante, I., Zepa, I. and Akota, I. 2018. 3D Assessment of nasolabial appearance in patients with complete unilateral cleft lip and palate. The Cleft Palate-Craniofacial Journal. 55(2), 220-225.

\section{Publikācijas Latvijā citējamos zinātniskos izdevumos}

1. Bāgante, I. un Akota, I. 2013. Deguna estētikas novērtējums pacientiem ar vienpusēju caurejošu lūpas, alveolārā izauguma un aukslēju škseltni. RSU Zinātniskie raksti. 421-427.

2. Bāgante, I. un Akota, I. 2014. Deguna elpošanas funkcijas salīdzinājums starp pacientiem ar vienpusēju caurejošu lūpas, alveolārā izauguma un aukslēju šķeltni un kontroles grupu. RSU Zinātniskie raksti. 340-344.

\section{Mutiskās prezentācijas starptautiskās zinātniskajās konferencēs}

1. Bagante I., Akota I., Barkane B. The Nose appearance in patients with unilateral complete cleft lip and palate. 11th Joint Symposium Rostock - Riga. Rostoka, Vācija, 04-05.05.2012.

2. Bagante I., Akota I., Barkane B. Эстетическая оценка первичной коррекции носа у детей с односторонней сквозной расщелиной губы, альвеолярного отростка и нёба. 17. Starptautiskais sejas un žokḷu ķirurgu un zobārstu kongress. Pēterburga, Krievija 15-17.05.2012, tēzes 20-21. lpp.

3. Bagante I., Akota I. The nasal function in patients with complete unilateral cleft lip and palate. 21.Internacionālā mutes sejas un žokḷu ķirurg̣ijas konference. Barselona, Spānija 21-24.10.2013, tēzes - International Journal of Oral and Maxillofacial surgery, Vol 42, Issue 10, 2013, Oct, 1194.lpp.

4. Akota I., Bagante I. Cleft treatment in Riga cleft Lip and Palate Centre. Symposium "Challenges in the treatment of cleft lip and palate", Bukareste, Rumānija 31.03-02.04.2014.

5. Bagante I., Akota I. The nasal function in patients with complete unilateral cleft lip and palate and control group. 12. Joint Symposium Rostock - Riga Rīga, Latvija 09-10.05.2014, tēzes 61-62.lpp.

6. Bagante I., Akota I., Bitans E. The 3D Nasolabial Evaluation in Cleft Patients. IADR/PER congress, Dubrovņiki, Horvātija 10.-13.09.2014, tēzes nr. S 0584. (https://live.blueskybroadcast.com).

7. Bagante I., Akota I., Bitans E. The three-dimensional nasolabial appearance in patients with complete unilateral cleft lip and palate. XXII Congress of the European Association for Cranio-Maxillo-Facial Surgery, Prāga, Čehija 23.-26.09.2014, tēzes nr. 0-0505, 95. Lpp.

8. Bagante I., Zepa I., Akota I. Nasal function and nasolabial appearance in patients with unilateral complete cleft lip, alveolus and palate in Riga Cleft Lip and Palate Centre. 10th European Craniofacial Congress, Gēteburga, Zviedrija 24-27.06.2015, tēzes nr. 3363. 
9. Zepa I., Bagante I., Akota I. Facial growth results in patients with non-syndromic complete UCLP treated with one-stage and two-stage palatal repair. 10th European Craniofacial Congress, Gēteburga, Zviedrija 24-27.06.2015, tēzes nr. 2231.

10. Bagante I., Akota I. Nasal function and 3D appearance in patients with unilateral complete cleft lip, alveolus and palate in Riga Cleft Lip and Palate Centre. 13th Joint Symposium Riga-Rostock, Rostoka, Vācija 5-7.05.2016.

11. Bagante I., Akota I. Nasal Function and 3D nasal appearance in patients with clefts and control group. 9. Baltijas sejas, žokḷu un plastiskās ķirurǵijas kongress (BAMPS), Tartu, Igaunija 12-13.05.2017, tēzes 19. Lpp.

\section{Mutiskās prezentācijas Latvijas zinātniskajās konferencēs}

1. Bāgante I., Akota I. Deguna estētikas novērtējuma metodes aprobācija bērniem ar vienpusējām caurejošām lūpas, alveolārā izauguma un aukslēju šķeltnēm. Rezidentu XIV zinātniski - praktiskā konference „Aktualitātes medicīnā”, Rīga, Latvija 08.06.2011.

2. Bāgante I., Akota I. Deguna elpošanas funkcija pacientiem ar vienpusēju caurejošu lūpas, alveolārā izauguma un aukslēju škseltni. RSU 12. zinātniskā konference, Rīga, Latvija 21-22.03.2013, tēzes 298.1pp.

3. Bāgante I., Akota I., Bitāns E. Deguna un lūpas novērtējums pacientiem ar vienpusēju caurejošu lūpas, alveolārā izauguma un aukslēju šķeltni. RSU 13. zinātniskā conference, Rīga, Latvija 10-11.04.2014, tēzes 321.lpp.

4. Bāgante I., Akota I., Zepa I. Deguna elpošanas funkcija un simetrija pacientiem ar vienpusēju caurejošu lūpas, alveolārā izauguma un aukslēju šķeltni. RSU 14. zinātniskā konference, Rīga, Latvija 26-27.03.2015, tēzes 301.lpp.

5. Bāgante I., Akota I. Deguna simetrijas un elpošanas funkcijas novērtējums pacientiem ar iedzimtām škseltnēm, salīdzinot ar kontroles grupu. RSU 16. zinātniskā konference, Rīga, Latvija 6-7.04.2017, tēzes 32.lpp.

6. Bāgante I., Akota I. Deguna elpošanas funkcija un simetrija bērniem ar vienpusēju caurejošu lūpas, alveolārā izauguma un aukslēju šķeltni. 8. Latvijas Ārstu kongress, Rīga, Latvija 21.-23.09.2017.

\section{Stenda referāti starptautiskās zinātniskajās konferencēs}

1. Bagante I., Akota I., Barkane B. The nasal correction in the patients with unilateral complete cleft lip and palate. 10th Joint Symposium Rostock-Riga,Riga, Latvia, 07.-10.05.2009, tēzes Stomatologija, Baltic Dental and Maxillofacial Journal (2009), Suppl.6 23.lpp.

2. Bagante I., Akota I., Barkane B. The nose assesment methodology in patients with unilateral complete cleft lip and palate. 7. Baltijas sejas, žokḷu un plastiskās ķirurğijas kongress, Riga, Latvia 20.-22.05.2010, tēzes 63-64.lpp.

3. Bagante I., Akota I., Klimecs V. Rhinomanometry in patients with unilateral complete cleft lip and palate in Riga Cleft Lip and Palate Centre. 8. Baltijas sejas, žokḷu un plastiskās ķirurğijas kongress (BAMPS), Kauņa, Lietuva 10.-11.05.2013, tēzes 46-47.lpp.

4. Bagante I., Akota I. Results of rhinomanometric investigation in patients with unilateral complete cleft lip and palate. 2nd International Medical Meeting 17th LDVA congress, Riga, Latvia 14-15.06.2013, tēzes 43.lpp.

5. Akota I., Bagante I. The 3D nasal appearance in patients with complete unilateral cleft lip and palate. $23^{\text {rd }}$ Congress of the European association for Cranio Maxillo-Facial Surgery (EACMF), Londona, Lielbritānija 13-16.09.2016, tēzes 52.lpp, nr. 0825. 


\section{Stenda referāti Latvijas zinātniskajās konferencēs}

1. Bāgante I., Akota I. Primāra un sekundāra deguna korekcija pacientiem ar vienpusēju caurejošu lūpas, alveolārā izauguma un aukslēju šķeltni. RSU 8. zinātniskā konference, Rīga, Latvija 02.-03.04.2009, tēzes, 209.lpp.

2. Bāgante I., Akota I., Barkāne B. Primāra deguna korekcija pacientiem ar vienpusēju caurejošu lūpas, alveolārā izauguma un aukslēju škseltni. RSU 9. zinātniskā konference, Rīga, Latvija 18.-19.03.2010, tēzes, 307.lpp.

3. Bāgante I., Akota I. Deguna novērtējums pēc plastiskajām operācijām trīsdimensiju (3d) attēlos. RSU 15. Zinātniskā konference. Rīga, Latvija 17-18.03.2016, tēzes 217.lpp. 


\section{PATEICĪBAS}

Vēlos izteikt pateicību savai darba vadītājai profesorei Ilzei Akotai, bez kuras palīdzības un zināšanām šis darbs nebūtu iespējams. Paldies par ieguldīto laiku, vērtīgiem padomiem un par piedalǐšanos deguna estētikas novērtēšanā 2D fotoattēlos. Paldies par iedrošināšanu uzstāties konferencēs ar mutiskiem referātiem.

İpašs paldies Elvisam Railijam Bitānam par ieguldīto laiku un palīdzību datu ievākšanas procesā kopīgi apgūstot jaunās tehnologíjas.

Paldies manai mīlajai kolēgei Inai Freimanei par sapratni un pacietību darba tapšanas laikā un par dalību deguna estētikas novêrtēšanā $2 \mathrm{D}$ fotoattēlos ar vizuālo analogu skalu.

Paldies Ievai Greitānei par ieguldīto laiku un palīdzību gan materiālu vākšanā, sagatavošanā, gan piedaloties deguna estētikas novērtěšanā 2D fotoattēlos ar vizuālo analogu skalu.

Paldies profesorei Ilgai Urtānei par atsaucību un iespēju veikt darbu RSU Stomatologíjas institūtā.

Paldies Irēnai Rogovskai par palīdzību un padomiem statistikas jautājumos.

Paldies darba recenzentiem profesoram Aigaram Pētersonam un profesorei Rūtai Carei par ieguldīto laiku darba recenzēšanā.

Paldies maniem bērniem, vīra vecākiem un īpaši vīram Oskaram par izturību, sapratni, uzmundrinājumiem un ticību maniem spēkiem š̄i darba tapšanas laikā.

Bet vislielākais paldies manai mịlajai mammai, bez kuras šis darbs nebūtu iespējams, paldies par palīdzību gan tiešā, gan netiešā veidā. Paldies par izturību, sapratni un ieguldīto laiku.

Paldies visiem, kurus šeit nepieminēju, bet kuri ir man palīdzējuši un atbalstījuši darba tapšanas gaitā. 
PIELIKUMI 


\section{Deguna estētikas novērtēšanas metožu pozitīvās un negatīvās īpašīibas}

\begin{tabular}{|c|c|c|c|}
\hline Metode & $\begin{array}{l}\text { Metodes pozitīvās } \\
\text { īpašǐbas }\end{array}$ & $\begin{array}{l}\text { Metodes negatīvās } \\
\text { īpašíbas }\end{array}$ & Autori \\
\hline $\begin{array}{l}\text { Klīniska } \\
\text { izmeklēšana }\end{array}$ & $\begin{array}{l}\text { - Precīza } \\
\text { - Labi akceptēta } \\
\text { antropologistu } \\
\text { vidū }\end{array}$ & $\begin{array}{l}\text { - Subjektīva } \\
\text { - Mazāk uzticama } \\
\text { - Grūti atkārtojama } \\
\text { - Neiespējami } \\
\text { salīdzināt rezultātus } \\
\text { starp dažādiem } \\
\text { centriem } \\
\text { - Laikietilpīga gan } \\
\text { pacientam, gan } \\
\text { kirurgam }\end{array}$ & $\begin{array}{l}\text { (Becker et al., 1998), (Hurwitz et al., 1999), } \\
\text { (Nolst Trenité, 2002), (Al-Omari et al., 2003), } \\
\text { (Anastassov \& Chipkov, 2003), (Kim et al.., 2004), } \\
\text { (Sinko et al., 2005), (Nolst Trenité, 2006), } \\
\text { (Nagy \& Mommaerts, 2007), (Oosterkamp et al.., 2007), } \\
\text { (Reddy et al., 2008), (He et al., 2009b), } \\
\text { (Rossell-Perry \& Gavino-Gutierrez, 2011), } \\
\text { (Chaithanyaa et al., 2011), (Oti et al., 2014), } \\
\text { (Tang et al., 2016) }\end{array}$ \\
\hline 2D attēli & $\begin{array}{l}\text { - Vienkārša } \\
\text { - Ekonomiska } \\
\text { - Neinvazīva } \\
\text { - Ērta } \\
\text { - Nav jonizējoša } \\
\text { - Plaši pieejama } \\
\text { - Uzticama un } \\
\text { atkārtojama } \\
\text { - Ilgtermiņa } \\
\text { rezultāti tiek } \\
\text { uzglabāti pastāvīgi } \\
\text { - Iespējams } \\
\text { salīdzināt divas } \\
\text { ķirurǵiskas } \\
\text { metodes noškirtas } \\
\text { vietā un laikā } \\
\text { - Mazāk } \\
\text { nepieciešama } \\
\text { pacienta sadarb̄̄ba } \\
\text { - Nepieciešams } \\
\text { mazāks } \\
\text { novērtēšanas laiks } \\
\text { - Nav nepieciešams } \\
\text { augsti kvalificēts } \\
\text { personāls }\end{array}$ & $\begin{array}{l}\text { - Svarīga pareiza } \\
\text { pacienta pozīcija } \\
\text { - Svarīga pareiza } \\
\text { galvas orientācija } \\
\text { - Iespējamas } \\
\text { izkroplojuma kḷūdas } \\
\text { - Lūpu kustības nevar } \\
\text { novērtēt } \\
\text { - Svarīgs } \\
\text { apgaismojums } \\
\text { - Nav piemērots } \\
\text { absolūtiem } \\
\text { mērījumiem, jo } \\
\text { pastāv palielinājums } \\
\text { - Punktu atlikšana var } \\
\text { būt neprecīza } \\
\text { - Viens 2D attēls } \\
\text { nevar precīzi atainot } \\
\text { visas sejas pazīmes }\end{array}$ & 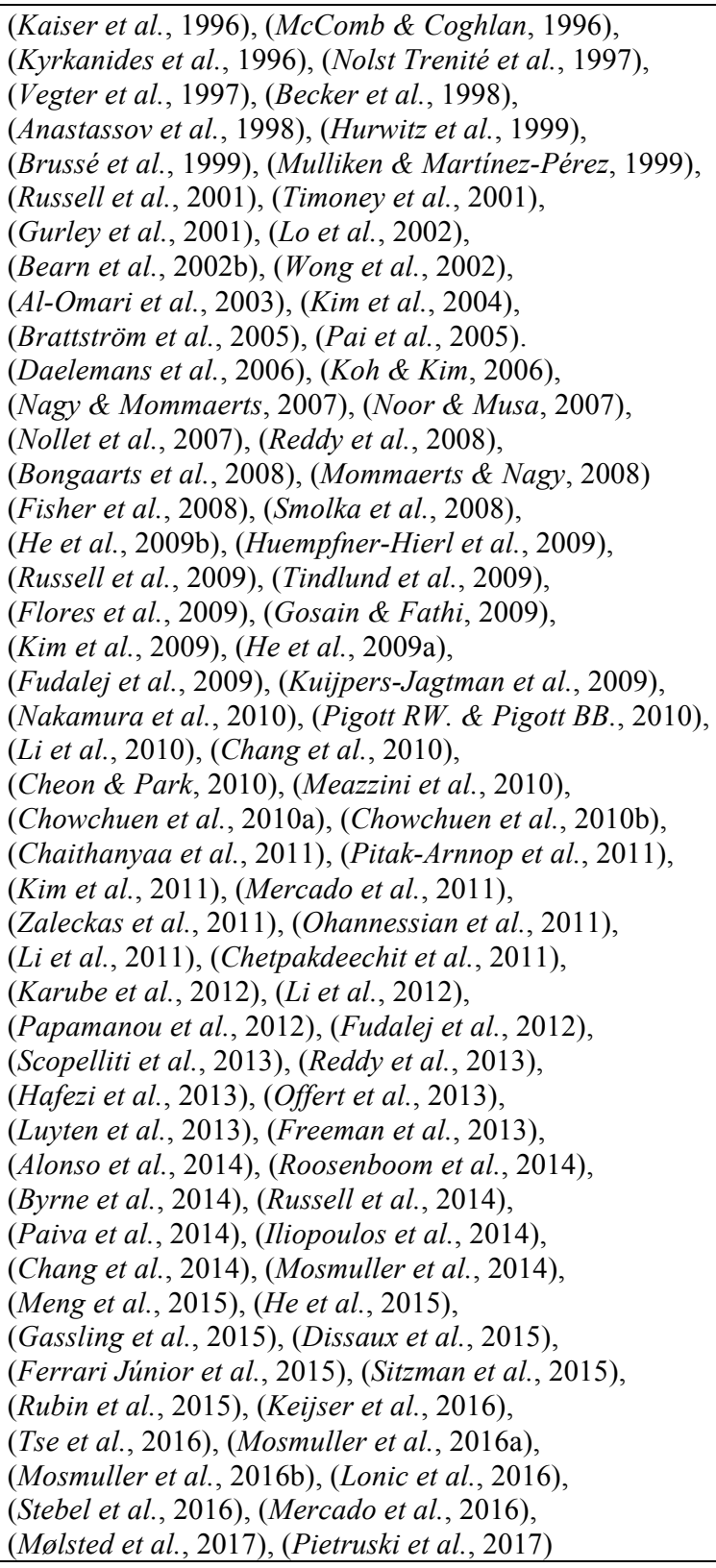 \\
\hline
\end{tabular}


Deguna estētikas novērtēšanas metožu pozitīvās un negatīvās īpašības (turpinājums)

\begin{tabular}{|c|c|c|c|}
\hline Metode & $\begin{array}{l}\text { Metodes pozitīvās } \\
\text { īpašības }\end{array}$ & $\begin{array}{l}\text { Metodes negatīvās } \\
\text { īpašības }\end{array}$ & Autori \\
\hline 3D attēli & $\begin{array}{l}\text { - Uzticama } \\
\text { - Precīza } \\
\text { - Droša } \\
\text { - Neinvazīva } \\
\text { - Kvalitatīva } \\
\text { - Kvantitatīva } \\
\text { - Atkārtojama } \\
\text { - Ātra } \\
\text { - Nav jonizējoša } \\
\text { - Var lietot bērniem } \\
\text { - Uzlabo datu } \\
\text { apstrādes iespējas } \\
\text { - Atvieglo ilgstošu } \\
\text { datu uzglabāšanu } \\
\text { - Digitāls pacienta } \\
\text { modelis var tikt } \\
\text { nekavējoties } \\
\text { izmantots klīniskām } \\
\text { vajadzībām } \\
\text { - Nelielas kl̄ūdas sejas } \\
\text { anatomisko punktu } \\
\text { atlikšanā nav } \\
\text { statistiski nozīmīgas }\end{array}$ & $\begin{array}{l}\text { - Dārga aparatūra un } \\
\text { programmas } \\
\text { - Nepieciešams laiks, } \\
\text { lai sagatavotu } \\
\text { subjektu un iegūtu } \\
\text { datus } \\
\text { - Apgaismojuma } \\
\text { nosacījumi } \\
\text { - Nav pārnēsājama } \\
\text { sistēma } \\
\text { - 3D fotogrāfiju } \\
\text { rekonstrukcijā var } \\
\text { rasties kḷūdas } \\
\text {-3D aparatūrai un } \\
\text { programmatūrai ir } \\
\text { 3D rekonstrukcijas } \\
\text { ierobežojumi } \\
\text { - Nāsis ir kḷūdu rajons } \\
\text { - Nav iespējams atlikt } \\
\text { kaulainās daļas vai } \\
\text { interaktīvos punktus } \\
\text { - Trūkst digitālo attēlu } \\
\text { datubāzes normatīvi }\end{array}$ & $\begin{array}{l}\text { (Yamada et al., 1999), (Duffy et al., 2000), } \\
\text { (Yamada et al., 2002), (Al-Omari et al., 2003), } \\
\text { (Hood et al., 2003), (Ferrario et al., 2003), } \\
\text { (Hood et al., 2004), (Singh et al., 2005), } \\
\text { (Mori et al., 2005), (Bilwatsch et al., 2006), } \\
\text { (Devlin et al., 2007), (Trotman et al., 2007), } \\
\text { (Weinberg et al., 2009), (van Loon et al., 2010), } \\
\text { (Nakamura et al., 2010), (Okawachi et al.., 2011), } \\
\text { (Ayoub et al., 2011), (Russell et al., 2011), } \\
\text { (Zreaqat et al., 2012), (Othman et al.., 2014), } \\
\text { (Bell et al., 2014), (Verzé et al., 2014), } \\
\text { (Tse et al., 2014), (Bugaighis et al., 2014a), } \\
\text { (Bugaighis et al., 2014b),(Bugaighis et al., 2014c), } \\
\text { (Desmedt et al., 2015), (Dadáková et al., 2016), } \\
\text { (Wu et al., 2016a), (Wu et al., 2016b), } \\
\text { (Stebel et al., 2016) }\end{array}$ \\
\hline $\begin{array}{l}\text { Laterālās } \\
\text { cefalogrammas }\end{array}$ & $\begin{array}{l}\text { - Akceptējama } \\
\text { ticamība } \\
\text { - Vienkārša } C T \\
\text { alternatīva ar } \\
\text { mazāku jonizējošo } \\
\text { starojumu }\end{array}$ & $\begin{array}{l}\text { - Nav pierādīta profila } \\
\text { mīksto audu } \\
\text { mērījumu ticamība }\end{array}$ & $\begin{array}{l}\text { (Smahel \& Müllerova, 1996), (Anastassov et al., 1998), } \\
\text { (Bearn et al., 2002a), (Yoon et al., 2003), } \\
\text { (Brattström et al., 2005), (Russell et al., 2009), } \\
\text { (Tindlund et al., 2009), (Chaithanyaa et al., 2011), } \\
\text { (Ridgway et al. }, 2011),(\text { Papamanou et al., 2012), } \\
\text { (Scopelliti et al., 2013), (Verzé et al., 2014) }\end{array}$ \\
\hline $\begin{array}{l}\text { Dator- } \\
\text { tomogrāfija }\end{array}$ & $\begin{array}{l}\text { - Mērījumi var tikt } \\
\text { atkārtoti un } \\
\text { pārbaudīti } \\
\text { - Ieraksti ir pastāvīgi } \\
\text { - Sniedz informāciju } \\
\text { par cietajiem audiem } \\
\text { - Lieliska metode, lai } \\
\text { kvantitatīvi noteiktu } \\
\text { sejas virsmu un } \\
\text { dzil̄ās kraniofaciālās } \\
\text { struktūras } \\
\text { - Kvantitatīvi var } \\
\text { novērtēt deguna } \\
\text { starpsienu } \\
\text { - Attēlus var apskatīit } \\
\text { vairākās pozīcijās } \\
\text { - Var novērtēt mīksto } \\
\text { audu un cieto audu } \\
\text { anatomiskos punktus } \\
\text { - Nav muskul̦u } \\
\text { kustību vai citi ārēji } \\
\text { deformējoši faktori } \\
\text { (ja lietota sedācija) }\end{array}$ & $\begin{array}{l}\text { - Radiācijas } \\
\text { ekspozīcija } \\
\text { - Sedācijas } \\
\text { nepieciešamība } \\
\text { maziem bērniem } \\
\text { - Sejas virsmas } \\
\text { tekstūra ir vāji } \\
\text { nosakāma }\end{array}$ & $\begin{array}{l}\text { (Fisher et al., 1999), (Suri et al., 2008), } \\
\text { (Nagasao et al., 2008), (Miyamoto \& Nakajima, 2010), } \\
\text { (Li et al., 2012), (Miyamoto et al., 2012), } \\
\text { (Scopelliti et al., 2013), (Alonso et al., 2014) }\end{array}$ \\
\hline
\end{tabular}




\section{Deguna estētikas novērtēšanas metožu pozitīvās un negatīvās īpašības (nobeigums)}

\begin{tabular}{|c|c|c|c|}
\hline Metode & $\begin{array}{l}\text { Metodes pozitīvās } \\
\text { ipašības }\end{array}$ & $\begin{array}{l}\text { Metodes negatīvās } \\
\text { īpašǐbas }\end{array}$ & Autori \\
\hline $\begin{array}{l}\text { Dentālie/ sejas } \\
\text { veiduļi }\end{array}$ & $\begin{array}{l}\text { - Vienkārši } \\
\text { - pieejami } \\
\text { - Lēti } \\
\text { - Objektīvi } \\
\text { - Kvantitatīvi } \\
\text { - Uzticami } \\
\text { - Precīzi } \\
\text { - Mērījumi var tikt } \\
\text { atkārtoti un } \\
\text { paplašināti } \\
\text { - Ataino } \\
\text { trīsdimensiju } \\
\text { struktūru } \\
\text { - Izslēdz mīksto } \\
\text { audu } \\
\text { izkroplojumu } \\
\text { - Netraucē } \\
\text { pacientu }\end{array}$ & $\begin{array}{l}\text { - Laikietilpīgi } \\
\text { - Grūti piemērojami } \\
\text { klīniskā praksē }\end{array}$ & $\begin{array}{l}\text { (Kaiser et al., 1996), (Russell et al., 2000), } \\
\text { (Russell et al., 2001), (Mishima et al., 2002), } \\
\text { (Dusková et al., 2002),(Bongaarts et al., 2008), } \\
\text { (Russell et al., 2009), (Tindlund et al., 2009), } \\
\text { (Barillas et al., 2009), (Russell et al., 2011) } \\
\text { (Reiser et al., 2011) }\end{array}$ \\
\hline Video ieraksti & $\begin{array}{l}\text { - Atluauj novērtēt } \\
\text { kustības } \\
\text { - No video } \\
\text { ierakstiem var } \\
\text { tikt generētas } \\
\text { fotogrāfijas } \\
\text { - Nav } \\
\text { nepieciešamas } \\
\text { klīniskas } \\
\text { fotogrāfijas }\end{array}$ & $\begin{array}{l}\text { - Laikietilpīga } \\
\text { - Nepieciešama } \\
\text { pacienta sadarbība } \\
\text { - Vairāki rediḡěšanas } \\
\text { posmi var novest pie } \\
\text { attēla izkroplojuma } \\
\text { - Nepieciešams } \\
\text { speciāli apmācīts } \\
\text { personāls }\end{array}$ & $\begin{array}{l}\text { (Morrant \& Shaw, 1996), (Russell et al., 2000), } \\
\text { (Trotman et al., 2007), (Dissaux et al., 2015) }\end{array}$ \\
\hline $\begin{array}{l}\text { Rinomanometrija, } \\
\text { deguna funkcija }\end{array}$ & & & $\begin{array}{l}\text { (Anastassov et al., 1998), (Huempfner-Hierl et al., 2009), } \\
\text { (Chaithanyaa et al., 2011), (Reiser et al., 2011), } \\
\text { (Keijser et al., 2016) }\end{array}$ \\
\hline Kombinācijas & & & $\begin{array}{l}\text { (Kaiser et al., 1996), (Becker et al., 1998), } \\
\text { (Anastassov et al., 1998), (Hurwitz et al., 1999), } \\
\text { (Russell et al., 2000), (Russell et al., 2001), } \\
\text { (Al-Omari et al., 2003), (Kim et al., 2004), } \\
\text { (Brattström et al., 2005), (Nagy \& Mommaerts, 2007), } \\
\text { (Reddy et al., 2008), (Bongaarts et al., 2008), } \\
\text { (He et al., 2009b), (Huempfner-Hierl et al., 2009), } \\
\text { (Russell et al., 2009), (Tindlund et al., 2009), } \\
\text { (Nakamura et al., 2010), (Chaithanyaa et al., 2011), } \\
\text { (Reiser et al., 2011), (Li et al., 2012), } \\
\text { (Papamanou et al., 2012), (Scopelliti et al.., 2013), } \\
\text { (Luyten et al., 2013), (Alonso et al., 2014), } \\
\text { (Verzé et al., 2014), (Roosenboom et al.,, 2014), } \\
\text { (Gassling et al., 2015), (Dissaux et al., 2015), } \\
\text { (Keijser et al., 2016), (Stebel et al., 2016) }\end{array}$ \\
\hline Cita / nav uzrādīta & & & (Cho \& Baik, 2001), (Tanikawa et al., 2010) \\
\hline
\end{tabular}


RSU Ētikas komitejas ațauja

Veidlapa Nr. E-9 (2)

RSU ËTIKAS KOMITEJAS LËMUMS

Rīga, Dzirciema icla 16, LV-1007

Tel. 67409089

Komitejas sastāvs Kvalifikācija Nodarbošanās

$\begin{array}{lll}\text { 1. Asoc. prof. Olafs Brūvers } & \text { Dr.theo. } & \text { teologs } \\ \text { 2. Profesore Vija S̄̄le } & \text { Dr.phil. } & \text { filozofs } \\ \text { 3. Docente Santa Purvina } & \text { Dr.med. } & \text { farmakologs } \\ \text { 4. Asoc. prof. Voldemārs Arnis } & \text { Dr.biol. } & \text { rehabilitologs } \\ \text { 5. Profesore Regīna Kleina } & \text { Dr.med. } & \text { patalogs } \\ \text { 6. Asoc. prof. Guntars Pupelis } & \text { Dr.med. } & \text { kirurgs } \\ \text { 7. Asoc. prof. Viesturs Liguts } & \text { Dr.med. } & \text { toksikologs }\end{array}$

\section{\begin{tabular}{ll}
\hline Picteikuma iesniedzēis: & Ieva Bāgante \\
& Riggas Stradiṇa universitātes Mutes, sejas un žokḷu
\end{tabular} kirurgijas katedras ārste}

\section{Pētījuma nosaukums:}

„Deguna elpošanas funkcija un estētika bērniem ar vienpusēju caurejošu lūpas, alveolārā izauguma un auksiēju šķeltni."

Iesniegšanas datums:

27.09.2012.

Pêtīiuma protokols:

Pêtījums kvalificējams kā prospektīvs kvalitatīvs projekts, kā arī kvantitatīvs pētījums, izmantojot statisisku apstrādi un analìzi.

Pẹtīuma populäcija:

visi Latvijas šḳclṭıu centrā registrētie un Latvijā dzimušie bērni no 1994.gada ar vienpusēju caurejošu lūpas, alveolārā izauguma un aukslẹju šḳeltni- sistemātiskas atlases lielums 88 .

Komitejas lēmums:

piekrist pētījumam

Paraksts

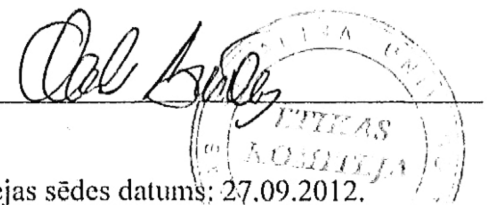

Ẽtikas komitejas sēdes datums: 27.09.2012. 
Pētījuma dalībnieku piekrišanas forma pētījuma grupai

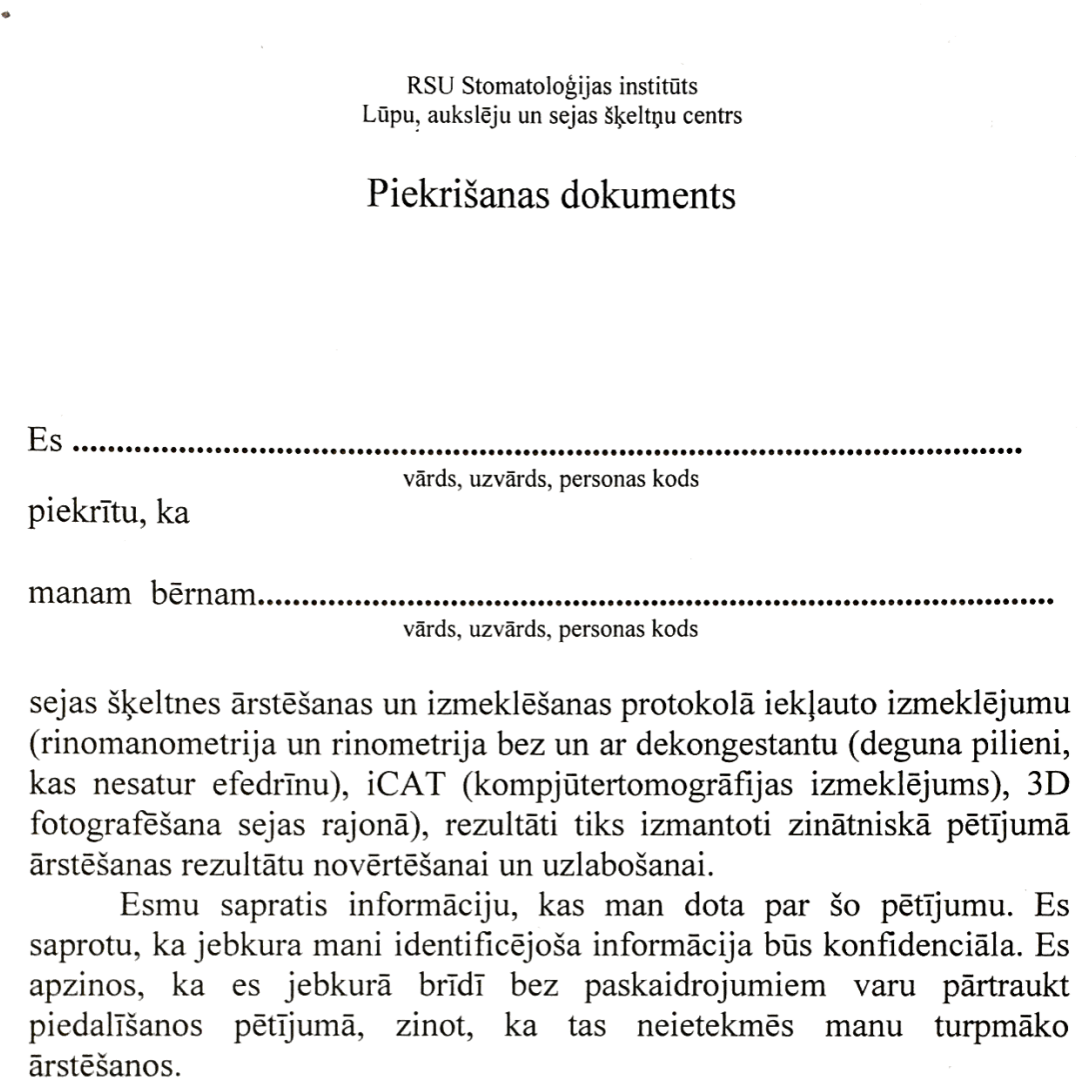
ārstēšanos.

Bērna vecāki/aizbildņi:

$$
\text { paraksts }
$$

datums

Pētnieks

paraksts

datums 
Pētījuma dalībnieku rinomanometrijas piekrišanas forma kontroles grupai

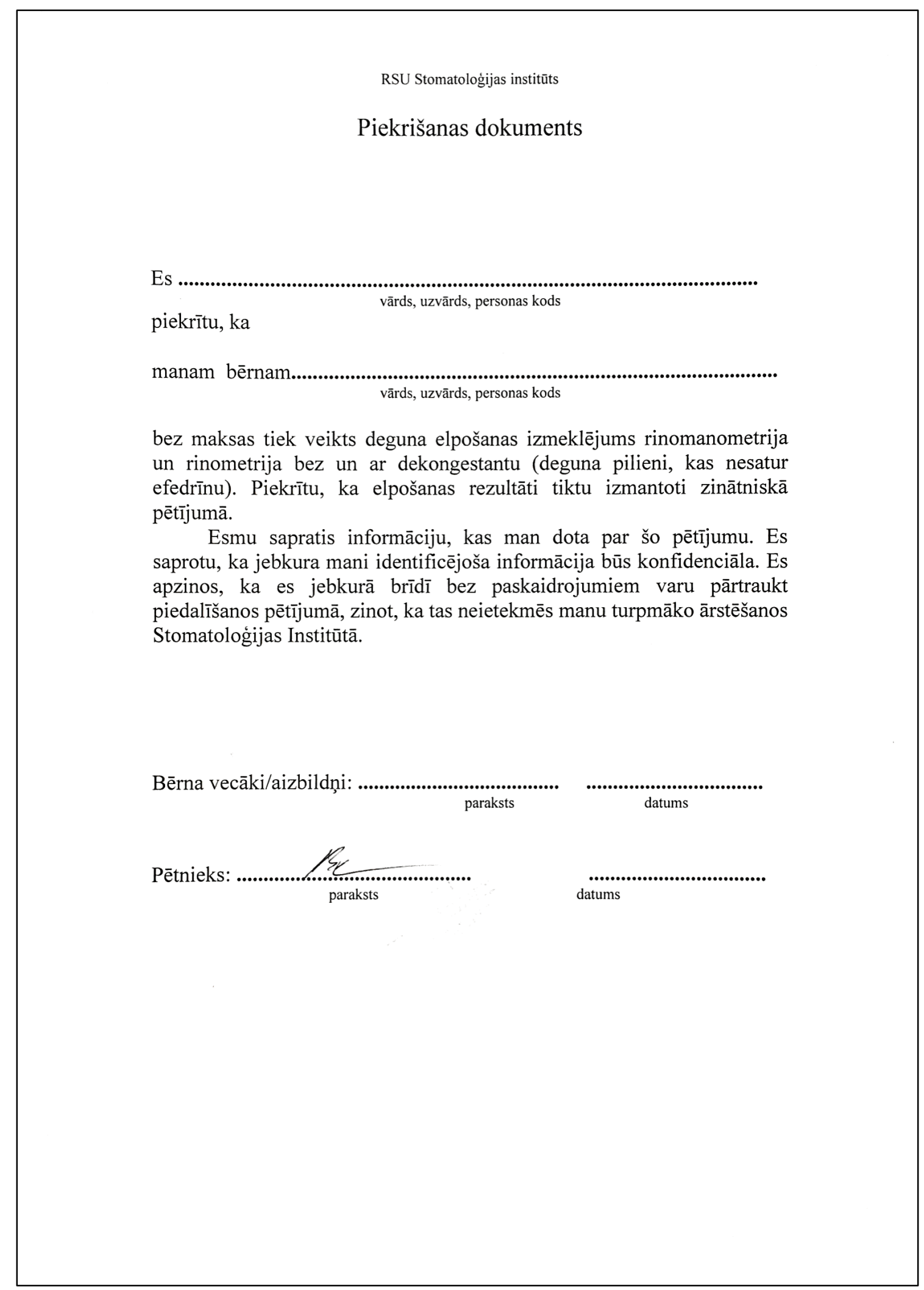


Pētījuma dalībnieku 3D foto piekrišanas forma kontroles grupai

RSU Stomatologijas Institũts

Piekrišanas apliecinảjums piedalīties pētījumā

Es (vārds, uzvārds), apliecinu, ka esmu saṇēmusi/is skaidrojumu par sejas augšanas pētījumu un mana bērna sejas stereofotogrammetrijas attēla iegūšanu ik pēc 6 mēnešiem 8 gadu garumă. Esmu saṇēmusi/-is informāciju, ka metode nav kaitīga veselībai un izmeklēšanas procedūra nav apgrūtinoša. Kā arī esmu saņëmusi/-is informāciju par to, ka esmu tiesīga/-s atsaukt savu piekrišanu, un tas neietekmēs mana bērna iespēju turpmāk ărstêties RSU Stomatologiijas institūtā. 